\title{
CRITICAL RACE PRAXIS: RACE THEORY AND POLITICAL LAWYERING PRACTICE IN POST- CIVIL RIGHTS AMERICA
}

\author{
Eric K. Yamamoto*
}

\section{Prologue}

At the end of the twentieth century, the legal status of Chinese Americans in San Francisco's public schools turns on a requested judicial finding that a desegregation order originally designed to dismantle a system subordinating nonwhites now invidiously discriminates against Chinese Americans. Brian Ho, Patrick Wong, and Hilary Chen, plaintiffs in Ho v. San Francisco Unified School District, ${ }^{1}$ represent "all $[16,000]$ children of Chinese descent" eligible to attend San Francisco's public schools. ${ }^{2}$ Their high-profile suit, filed by small-firm attorneys, challenges the validity of a 1983 judicial consent decree desegregating San Francisco's schools. Approved in response to an NAACP class action charging educational discrimination by whites, the consent decree mandates racial and ethnic diversity in student bodies and sets for each "magnet" school a forty-percent cap for students from any racial or ethnic group. ${ }^{3}$

* Professor of Law, William S. Richardson School of Law, University of Hawai'i. J.D. 1978, Boalt. - Ed. Copyright Eric K. Yamamoto 1996. I am deeply grateful to Angela Harris, Gerald López, Sumi Cho, and Dale Minami for their inspiring work and counsel. I am also especially appreciative of Susan Serrano for her invaluable contributions as principal researcher. My thanks also to research assistants Juliette Sheehan Dwight, Francis Leung, Dayna-Ann Mendonca, Issac Moriwake, Dan Mueller, and Sheri Ritter.

1. See First Amended Class Action Complaint for Declaratory and Injunctive Relief for Violations of 42 U.S.C. § 1983 at 1, Ho v. San Francisco Unified Sch. Dist., (N.D. Cal. Mar. 8, 1986) (No. C-94-2418-WHO) [hereinafter First Amended Complaint].

2. See Memorandum Decision and Order at $8, \mathrm{Ho}$ v. San Francisco Unified Sch. Dist., (N.D. Cal. Mar. 8, 1996) (No. C-94-2418-WHO) [hereinafter Memorandum Decision and Order].

3. See Consent Decree, San Francisco NAACP v. San Francisco Unified Sch. Dist., 576 F. Supp. 34, 53 (N.D. Cal. 1983) [hereinafter Consent Decree]. The Consent Decree categorizes students into one of nine racial or ethnic groups: Spanish sumame, Other White, Black, Chinese, Japanese, Korean, Filipino, American Indian, and Other Non-White. See Consent Decree, supra, at 5. It requires that at least four racial or ethnic groups be represented at each school. See id. at 6 . To assure diversity the decree caps at $40 \%$ the enrollment of any particular group at any "alternative school" (or "magnet" school such as Lowell High School) and at $45 \%$ at any regular school. See id. The plaintiffs assert that but for the cap, Chinese Americans now would matriculate in numbers in excess of $40 \%$ based on entrance exam scores. See First Amended Complaint, supra note 1, at 9. 
Early on, Chinese Americans benefited from the decree's diversity mandate, substantially increasing their enrollments. ${ }^{4}$

The Chinese American plaintiffs now seek to exceed the fortypercent cap by claiming that the cap constitutes unconstitutional race preferencing for those less qualified, particularly African Americans and Latinos. Discrimination is demonstrated, the plaintiffs allege, by the denial of magnet school admission to some Chinese American students despite their entrance test scores, which are higher than those of some matriculated students of other races. 5 They observe that this form of exclusion is consistent with California's history of harsh discrimination against Chinese Americans. ${ }^{6}$ Using ideas refined by neoconservative race scholars, their attorneys frame the suit in terms of individual rights, advance legal arguments of "meritocracy" and "colorblindness,"7 and seek to enjoin the school district "from operating under its system of racial classification and quotas."8 Some Chinese American supporters more directly express perceptions of underlying racial-cultural differences: formal racism in the system has ended; Chinese Americans have elevated themselves as a group through ability and cultural values despite hardship; African Americans have had the benefit of the decree for ten years "and black students" performance is still bad." Some plaintiffs and their supporters imply that Chinese American educational superiority - as measured by test scores - is at least

4. See Henry Der, The Asian American Factor in the Affirmative Action Debate: Victim or Shortsighted Beneficiary of Race-Conscious Remedies, in LEAP - COMMON GROUND: Perspectives on Afrirmative Action (1996) [hereinafter Der, Asian American Factor].

5. The complaint alleges:

[S]tudents of Chinese descent were required to score a minimum of 66 out of a possible 69, while applicants who were Other White, Japanese, Korean, Filipino, American Indian, or Other Non-White were required to score only 59, and students who were Hispanic or African American were required to score 56.

First Amended Complaint, supra note 1, at 10; see also Der, Asian American Factor, supra note 4 , at 3.

6. See People v. Hall, 4 Cal. 399 (1854); see also Tomas Almaguer, RACIAL FAulT LINES (1994).

7. "Plaintiffs simply do not wish to be classified on the basis of race or ethnicity ...." Plaintiffs' Memorandum of Points and Authorities in Opposition to Defendants' Motion to Dismiss at 3 n.2, Ho v. San Francisco Unified Sch. Dist., (N.D. Cal. Mar. 8, 1996) (No. C-942418-WHO) [hereinafter Opposition Memorandum to Defendants' Motion to Dismiss]. See infra note 40 for discussion of neoconservative race scholarship and its connection to conservative political lawyering practice.

8. First Amended Complaint, supra note 1, at 18.

9. Mamie Huey, Chinese Americans Have Bone to Pick with Consent Decree, AsIaNWEek, Jan. 27, 1995, at 5, 8 [hereinafter Huey, Bone to Pick]. 
partially a reflection of cultural if not intellectual inferiority of African Americans and Latinos. ${ }^{10}$

Plaintiffs' strategy of distancing Chinese Americans from African Americans is refiected not only in statements of supporters but also in plaintiffs' legal filings. In those filings, plaintiffs' attorneys assert that Chinese American students' interests are contrary to the interests of African American students represented by the NAACP and that the NAACP "did not adequately represent" Chinese Americans in the original desegregation action.11 The attorneys also contend that the defendant NAACP "is a proponent of the status quo, while Plaintiffs consider the Consent Decree a violation of their right to equal protection." 12 The NAACP, represented by a large law firm and a civil rights litigation organization, publicly opposes the suit and serves as the primary defender of the consent decree. ${ }^{13}$

Chinese American political and cultural organizations are sharply divided. Some offer strong support for the plaintiffs and stress the value of individual achievement and educational opportunities for Chinese American children. ${ }^{14}$ Others voice strident opposition, find no evidence of school-choice discrimination against Chinese American students (Chinese constitute by far the single largest group in magnet schools), question the framing of "merit" solely on the basis of an entrance test, and emphasize continuing systemic impediments to socio-economic advancement by African

10. See supra text accompanying note 9 and infra text accompanying note 18 . These arguments have received considerable recent public attention. See DINESH D'SouzA, THE END OF RACISM (1995) (arguing the cultural superiority of descendants of Asia and Westem Europe particularly in comparison with African Americans); RICHARD J. HERRNSTEIN \& Charles Murray, The Bell Curve $272-76$ (1994) (construing IQ test information to mean that Asian Americans and whites are innately more intelligent than African Americans and Latinos).

11. Opposition Memorandum to Defendant's Motion to Dismiss, supra note 7, at 10 , December 7, 1994.

12. Id.

13. See Mamie Huey, NAACP Sides With SF School District in Ongoing Lowell Saga, AsIANWEEK, Jan. 20,1995, at 5. Several organizations, including the Chinese for Affirmative Action, Mujeres Unidas Y Activas/Coalition for Immigrant and Refugee Rights, and the Latin American Teachers' Association, sought to intervene and support the Consent Decree. The court denied their request in part because it believed that the San Francisco NAACP would represent the interests of all minority organizations. The court did allow those organizations to participate as amici curiae. See Memorandum Decision and Order at 4, San Francisco NAACP v. San Francisco Unified Sch. Dist. (N.D. Cal. July 22, 1993) (No. C-78-1445WHO).

14. See Huey, Bone to Pick, supra note 9, at 8 (quoting one parent as saying "[p]arents don't think about ethnic groups, they're concerned with the suitable program for their kids"). 
Americans, Native Americans, Latinos, and some Asian Americans. ${ }^{15}$

Civil rights lawyers, Asian American organizations, and California politicians also diverge in their responses. Those supporting the suit talk about quotas, injustice, and civil rights. A spokesperson for the Asian American Legal Foundation indicated that Chinese Americans "will not stand for injustice and inequality in our community."16 The lawyer delivering the keynote address at the plaintiffs" fundraiser declared that "[w]e are on the right side of civil rights" and "we say 'never' to racial quotas on children."17 Legal supporters also talk about merit and racial differences: the NAACP "opposes us, but dropout rates for African American students have never been higher."18 Unsurprisingly, neoconservative politicians embrace these positions, arguing affirmative action's harm to Asian Americans as a ground for jettisoning affirmative action altogether. ${ }^{19}$

Lawyers and community leaders who oppose the suit talk about practical consequences. If the plaintiffs succeed, a likely immediate consequence will be more Asian American and white public school admittees with significantly fewer African Americans and Latinos. ${ }^{20}$ A likely longer-term consequence may be the legal dismantling of all race-based affirmative action programs in the state. ${ }^{21}$ Additionally, the law may well affirm in the public mind the image of Asian American superiority and African American and Latino inferiority. In light of probable consequences, a plaintiffs' "victory"

15. See Der, Asian American Factor, supra note 4, at 4 (as executive director of Chinese For Affirmative Action, opposing the $H o$ suit on multiple factual and philosophical grounds).

16. Huey, Bone to Pick, supra note 9, at 8.

17. Id.

18. Id.

19. See Frank H. Wu, Behind the GAO Report, AsIANweEk, Dec. 22, 1995, at 11 (reporting on white neoconservative politicians' use of Asian Americans to argue for abolition of affirmative action).

20. See Der, Asian American Factor, supra note 4, at 4. As a basis for comparison, a study of the 1994 entering freshmen at UCLA found that if students were admitted on "academic criteria alone" the number of Asians would increase (42.2\% to $51.1 \%$ ) as would the number of whites (30.7\% to $42.7 \%$ ), while the number of Hispanics and Blacks would decline sharply: $20 \%$ to $5 \%$, and $7.1 \%$ to $1.2 \%$, respectively. See Andrew Hacker, Goodbye to Affirmative Action?, N.Y. REv. OF Books, July 11, 1996, at 21 (table summarizing study results).

21. One apparent irony of the plaintiffs' position, which if successful will likely undermine all affirmative action programs, is that Chinese American supporters perceive continuing discrimination against Asian Americans in employment, housing and entitlements, among other things, and support affirmative action in those realms. See Der, Asian American Factor, supra note 4, at 7-8; Henry Der, Preliminary Analysis of Ho v. San Francisco Unified School District, Sept. 9, 1994, at para. 57 [hereinafter Der, Preliminary Analysis]. 
may well exacerbate African American and Asian American tensions already heightened by negative stereotypes held by some members of each group about the other, 22 by intergroup economic competition, ${ }^{23}$ and by intergroup justice grievances. ${ }^{24}$

Interestingly, progressive race theorists have not joined lawyers and activists behind the scenes or in the litigation trenches. ${ }^{25}$ Nor has their work, which critically interrogates questions of race, culture, and law, informed the framing, concepts, or language of the suit. ${ }^{26}$ Noticeably absent from litigation strategy and legal discourse is critical inquiry into the connection between law and racial

22. See Louis Harris Research, Taking America's Pulse: The Fall Report of the National Conference SuRVEy on INTERgroup Relations (1994). The poll found that almost half of all blacks and Latinos believe that Asian Americans are "wary, suspicious, and unfriendly toward non-Asians and "unscrupulously crafty and devious in business." Id. Thirty-five percent of Asians and $24 \%$ of African Americans think that "Latinos lack ambition and drive to succeed." Id. Thirty-one percent of Asian Americans and $26 \%$ of Latinos agree that "African Americans want to live on welfare." Id. The percentages of minorities harboring negative stereotypes are significant because they are higher than the percentages of whites who admit to such attitudes.

23. See infra note 157.

24. Those justice grievances, flowing from both groups, include the killing of Latasha Harlins by Soon Ja Du in 1991, the Ice Cube rap "Black Korea in 1991," the burning of Korean American stores in South Central Los Angeles in 1992, and the rancorous debates about California's Proposition 187 (immigration) and Civil Rights Initiative (affirmative action). See Jeff Chang, Race, Class, Conflict and Empowerment: On Ice Cube's "Black Korea," AMERAsia J., vol. 97 no. 2, 1993, at 87; Sumi K. Cho, Korean Americans vs. African Americans: Conflict and Construction, in READING RODNEY KinglReADING URBAN UPRISING 196, 196 (Robert Gooding-Williams ed., 1993); Neil Gotanda, Re-Producing the Model Minority Stereotype: Judge Joyce Karlin's Sentencing Colloquy in People v. Soon Ja Du, in ReViewing Aslan America 87, 92, 99 (Wendy L. Ng et al. eds., 1995); Our Next Race Question: The Uneasiness Between Blacks and Latinos, HARPER's MAG., Apr. 1996, at 55; infra note 157 (discussing interminority economic competition).

These tensions appear to have been somewhat lessened by multiracial coalition-building efforts addressing issues of race violence, immigration, and affirmative action. See Samuel R. Cacas, Minority Lawyers Organize Against California Save Our State Initiative, AsIANWEEK, Sept. 2, 1994, at 5 (describing community forum encouraging minority lawyers to challenge California's Proposition 187); Ben Q. Limb, New York Launches Black-Korean Mediation Project, NAPABA LAWYER, Oct. 1994, at 7 (reporting on Black-Korean mediation project designed to address intergroup conflict); New Coalition Formed to Address Racism in Southern California, RAFU SHMPO, June 12, 1992, at 1 (discussing multiracial women's coalition committed to the elimination of racism).

25. The two attorneys of record for the San Francisco and California state defendants work, respectively, for the State Department of Education and as a small-firm practitioner. Attorneys for the defendant San Francisco NAACP include a large, established California firm, a San Francisco civil rights organization, and two small-firm practitioners. See Civil Docket at 103, Ho v. San Francisco Unified Sch. Dist. (N.D. Cal. Mar. 12, 1996) (No. 94-CV2418). The lawyer for plaintiffs and the class is a named partner in a small San Francisco firm. In at least one court appearance he was accompanied by a law professor (who did not appear on the briefs or participate in argument). See id. at 1.

26. Two law students authored Notes in 1995 that discussed the Ho case. See Selena Dong, Note, "Too Many Asians": The Challenge of Fighting Discrimination Against Asian Americans and Preserving Affirmative Action, 47 STAN. L. REv. 1027, 1045 (1995); Alexandra Natapoff, Note, Trouble in Paradise: Equal Protection and the Dilemma of Interminority Group Conflict, 47 STAN. L. REv. 1059 (1995). 
hierarchy, including Asian Americans' purported role as "middle minority" buffers in the continuing subordination of African Americans; the political construction and implications of meritocracy and colorblindness in the affirmative action debate, including the meaning of objectivity and race consciousness; the dissonant understandings of "equality-under-law" (equality-of-opportunity, equality-ofresult, and anti-caste); and the sharp limitations of legal process for subordinated communities seeking racial justice, including the general failure of legal norms, methods and procedures to foster intergroup healing. ${ }^{27}$

Also noticeably missing from the legal filings, oral arguments, and court rulings, which focus on specific procedural or doctrinal issues, is critical inquiry into the interminority dynamics at the heart of the case. One aspect of those unstated dynamics is intergroup power. Is affirmative action, as neoconservatives argue, "discrimination against Asians in order to protect blacks"28 - making Asian Americans the "new victims" of racism and African Americans, and to a lesser extent Latinos, the "new perpetrators?" Or is this construction of interracial conflict a mask for continued white supremacy? A second aspect of unstated dynamics is the fit of civil rights law. Is the traditional antidiscrimination-law scheme workable for multiracial conflicts in post-civil rights America? Or is it necessary to remake the white on black jurisprudential paradigm? A third aspect is context. How do the volatile mid-1980s Asian American admissions controversy ${ }^{29}$ and the mid-1990s California

27. For a discussion of critical inquiry in cases in addition to Ho, see infra notes 162-83 and accompanying text (critically analyzing United Minorities Against Discrimination v. City of San Francisco) and Part IV (describing a critical race praxis).

28. Dana Y. Takagi, The Retreat From Race: Asian-American Admissions and RaCial Politics 139 (1992). The Asian-versus-black framing informs the support for the University of California Regents' 1995 decision to terminate all university affirmative action programs and the 1996 California ballot initiative to end affirmative action in state government. Conservative Congressman Dana Rohrbacher, in a 1995 press release accompanying a General Accounting Office report on college admissions prepared at his request, reiterated the neoconservative Asian-black rationale for eliminating affirmative action: "Young Asian Americans are being victimized by quota-based college admissions policies designed to benefit preferred minority groups. . . . The education establishment's race-obsessed admissions doctrine demonstrably discriminates against Asian Americans." Wu, supra note 19, at 11 (quoting Rohrbacher press statement) (emphasis added) (internal quotation marks deleted). The "preferred minority groups" to which Rohrbacher clearly referred were African Americans and Latinos.

29. See TAKAGI, supra note 28. The Berkeley controversy started with Asian American complaints about a hidden quota limiting admissions of Asian Americans. The administration's investigation determined that the decline was the result of a "series of deliberate policy changes' ... instituted [by the University] . . . knowing that they would reduce Asian American freshman enrollment at Berkeley." Id. at 34 (quoting 1985 report by Asian American Task Force on University Admissions). University officials responded to this revelation with tortured justifications of diversity and meritocracy, claiming first that Asian American 
Civil Rights Initiative and the University of California affirmative action repeal ${ }^{30}$ contextualize the intergroup issues in $\mathrm{Ho}^{31}$ And why do intergroup issues of apparent legal and political import, scrutinized by race scholars, appear to evaporate in Ho amid lawyerly formulation of legal argument and strategy?

\section{INTRODUCTION}

The $H o$ litigation, I suggest, reveals a disjuncture between progressive race theory and frontline political lawyering practice. In one realm, undertaking critical inquiry, progressive scholars offer theoretical insights about $\mathrm{Ho}^{\prime}$ 's pressing socio-legal issues. In another realm, amid growing criticism of race-conscious affirmative action, the NAACP and state's lawyers defend a race desegregation order both in court and in the arena of popular opinion. Yet, with much to share and with racial conditions in the balance, progressive theorists and lawyers seemingly fail to connect in meaningful ways.

students were overrepresented in universities nationwide (and should therefore be admitted in lesser numbers) and second that Asian Americans, despite high overall entrance test scores, were poorly qualified (they were "narrowly concentrated in technical fields and hence poor all-around candidates for the top schools"). Id. at 58. In the face of compelling criticism by scholars and activists and mounting protests, the Berkeley chancellor apologized and stopped the school's ceiling admissions practice for Asian Americans. See id. at 139.

The chancellor's apology hardly ended the controversy. Neoconservative politicians and activists, initially uninterested in Asian American civil rights, endeavored to shift the terms of the debate from Asian American exclusion in admissions to a general attack on affirmative action. Congressman Dana Rohrbacher, a sponsor of legislation to eliminate affirmative action in college admissions, in a 1989 speech to the Heritage Foundation, explained the reason for using Asian Americans to criticize affirmative action: "In a way, we want to help Asian Americans, but at the same time we're using it as a vehicle to correct what we consider to be a societal mistake." Wu, supra note 19 , at 11 (internal quotation marks omitted). To justify "correcting the mistake," neoconservatives argued that affirmative action for blacks and Latinos harmed Asian Americans (and whites).

Support from commentators such as Dinesh D'Souza (an Asian American who aligned Asians with whites against African Americans and Latinos, see, e.g., DINESH D'SOUZA, ILLIBERAL EDUCATION (1991), and heightened media coverage of neoconservative positions), recast the Asian American admissions debate. Dana Takagi unravels the shifting discourse: "Whereas Asian American organizations ... accused . . . officials of discrimination against Asians in order to protect whites, neoconservatives charged university officials with discrimination against Asians in order to protect blacks. According to neoconservative claims, discrimination was a matter . . . between blacks and Asians." TAKAGI, supra note 28, at 139.

30. See Bill Wong, Now Under Attack, Affirmative Action Is Complex, Contentious, AsIANWEEK, Feb. 24, 1995, at 9 (describing the Regents' vote to end university affirmative action and the California Civil Rights Initiative).

31. Henry Der, community activist and former head of Chinese for Affirmative Action, aptly connects $H o$ with the University of Califomia controversies and identifies a paramount challenge for Asian Americans in intergroup relations: "The true challenge facing Asian Americans today is not whether more Chinese or Asians can be enrolled at Lowell or UC Berkeley, but whether we will play a responsible role in creating and maintaining a multiracial democracy." Der, Asian American Factor, supra note 4, at 7-8. With that challenge comes a warning: "If not, Asian Americans face the real possibility of playing a leading role in a segregated society." Id. at 8. 
The disjuncture reflects something more than scholars coldly scrutinizing judicial opinions and lawyers heatedly struggling through the immediacy of adversarial decisionmaking. Something more is at play.

The Ho litigation also reveals another kind of separation influencing political lawyering practice: an intensifying dissociation of law (as it conceives of justice) from racial justice (as it is experienced by racialized groups). Ho illuminates three dimensions of this dissociation through its awkward embrace of a constricted civil rights law paradigm: First, the Chinese American plaintiffs appear to ignore the historical linkage of law and cultural representations to legalized racial oppression. They support their civil rights claims to equality under the law by disparaging other "less deserving" racial groups. Second, they uncritically employ rhetoric and assert claims shaped initially by African American civil rights struggles and recast later by neoconservative politicians and jurists to undermine minority claims of institutional racism and to sanction white claims of "reverse discrimination." In doing so, the plaintiffs generate confusion and anger among African Americans, Latinos, and other Asian Americans about the purpose of antidiscrimination laws and about $H o$ 's social meaning and impact. Third, and related, the plaintiffs invoke a civil rights paradigm that understands racial conflict narrowly in white-on-black, perpetrator-and-victim terms and fails to account for the unique dimensions of interracial group grievances and to facilitate possibilities for intergroup healing.

Although of continuing significance in ways discussed later, legal justice under the civil rights paradigm employed in $H o$ increasingly is experienced by racialized communities as racial injustice. Indeed, "embittered" and "frustrated and misunderstood" is how a professor and civil rights attorney describes her racial minority clients after "encounters with civil rights enforcement."32 These experiences are symptomatic of the law's intensifying dissociation from racial justice, or what one sociologist calls America's "retreat from racial justice." 33

Why the disjuncture? Why the dissociation? And what might be done? Put another way: In post-civil rights America, how might theorists, lawyers, and activists bridge both the "gap of chasmic proportions" 34 between progressive race theory and political lawyering

32. See infra note 145 and accompanying text.

33. See infra Part II.

34. Margaret M. Russell, De Jure Revolution?, 93 MrcH. L. REv. 1173, 1175 (1995) [hereinafter Russell, Revolution]. 
practice and the growing divide between law and racial justice? This article responds to the question of bridging. It offers the beginnings of a critical race praxis.

The first two Parts assess the problems just identified. Part I addresses a problem sensed by many but written about by few the disjuncture between progressive race theory and political lawyering practice. This disjuncture is especially problematic for those on the left in light of the coalescence of conservative race theory and political practice into a neoconservative praxis.

Part II addresses the intensifying dissociation of law from racial justice. This Part first describes the linkage of race and culture to legal injustice. It then examines the increasing constriction of civil rights antidiscrimination law for racial minorities, sketching five socio-legal explanations. Finally, exploring litigation of the United Minorities case, Part II identifies a salient limit of the traditional white-on-black civil rights paradigm: jurisprudential blindness to color-on-color.

Part III, responding to problems of disjuncture and dissociation, locates the rethinking of progressive race theory and political lawyering practice in a contemporary jurisprudence of reconstruction. Borrowing its name from post-civil war antislavery laws, that jurisprudence endeavors to reconstruct current antidiscrimination law realistically to address racial subordination in American society. For critical race theorists, that jurisprudence inhabits the tension between postmodernism, with its despairing unpacking of legal liberalism, and modernism, with its concepts of truth and justice that for people of color "have always been both indispensable and inadequate." 35 This Part also identifies the "practical turn" in critical race theory's reconstructive jurisprudence - a turn that employs tools of critical pragmatic inquiry to remake specific legal doctrines and evaluate aspects of legal process. My critique of the limits of that practical turn - its emphasis on courts and doctrine - leads to the beginning development in Part IV of what I call critical race praxis.

Critical race praxis combines critical, pragmatic, socio-legal analysis with political lawyering and community organizing to practice justice by and for racialized communities. Its central idea is that racial justice requires antisubordination practice. In addition to ideas and ideals, justice is something experienced through prac-

35. Angela P. Harris, Foreword: The Jurisprudence of Reconstruction, 82 CAL. L. REV. 741, 744 (1994) [hereinafter Harris, Jurisprudence of Reconstruction]. 
tice. As developed in Part IV, critical race praxis requires an understanding of justice in terms of both method - experiencerethinking-translation-engagement - and norm - first principles of antisubordination and rectification of injustice. It requires, in appropriate instances, using, critiquing, and moving beyond notions of legal justice pragmatically to heal disabling intergroup wounds and forge intergroup alliances. It also requires, for race theorists, enhanced attention to theory translation and deeper engagement with frontline practice; and for political lawyers and community activists, increased attention to a critical rethinking of what race is, how civil rights are conceived, and why law sometimes operates as a discursive power strategy.

What I offer in Part IV is a framework rather than a fully developed critical race praxis. As part of that framework, and drawing selectively upon insights of critical race theory, pragmatism, prophetic theology, feminist legal theory, and environmental justice scholarship, I suggest four starting points of race praxis inquiry: the conceptual, the performative, the material, and the reflexive. These starting points do not prescribe what racial justice is, or should be, in any particular situation. Rather, they offer guideposts toward collective, reflective antisubordination practice.

Part IV closes with a discussion of three main implications of critical race praxis: The first is the grounding of justice in concrete racial realities. It requires exploring the experiences of racial communities and locating theory development and application within their antisubordination struggles. The second is the reframing of racial justice claims and court process as cultural performances. This requires rethinking the cultural and communicative dimensions of justice claims, starting with law and emphasizing pragmatic conceptions of justice for racial groups. The third implication is the development of an interracial praxis. This praxis acknowledges continuing white dominance in many spheres of socio-economic life and expands justice inquiry beyond white on black and even white on color to encompass color on color. As part of that inquiry, an interracial praxis explores prospects of intergroup healing and assesses racial group agency and responsibility both enlivened and constrained by multiple contexts.

\section{The Disjuncture Between Progressive Race Theory} and Political Lawyering Practice

In post-civil rights America progressive race theorists, political lawyers, and community activists encounter a disjuncture between 
race theory and lawyering practice. ${ }^{36}$ On the one hand, those theorists, lawyers, and activists tend to respond in similar ways to America's rethinking of what justice means in a multicultural society. They acknowledge and struggle against growing despair in communities of color that are experiencing political and legal retrenchment of modest socio-economic gains, ${ }^{37}$ and they recognize and struggle against antidiscrimination law's constricted approach to racial justice. ${ }^{38}$ They engage in these struggles for at least one common ideological reason: the elimination or diminution of the material, real-world conditions of racial oppression. This, for them, defines racial justice. ${ }^{39}$

On the other hand, unlike the close connection between neoconservative race theory and political activism, ${ }^{40}$ progressive race

36. I define "progressive race theorist" and "political lawyer" broadly to encompass those committed to the elimination of racial oppression as part of a larger interconnecting project that seeks to eliminate all forms of subordination, including subordination based on gender, class, religion, national origin, sexual orientation, and disability. See generally MaRI J. Matsuda et al, Words That Wound: Critical Race Theory, Assaultive Speech, AND THE FIRST AMENDMENT 6-7 (1993) (describing how critical race theory works toward the broader goal of ending all forms of oppression); Francisco Valdes, Sissies, Dykes, and Tomboys: Deconstructing the Conflation of "Sex," "Gender," and "Sexual Orientation" in Euro-American Law and Society, 83 CAL. L. REv. 1 (1995) (describing the difference and interconnection among categories of subordination).

37. See Stephen Steinberg, Turning Back: The Retreat From Racial Justice in American Thought AND Policy 213 (1995); see also Kimberle Williams Crenshaw, Race, Reform, and Retrenchment: Transformation and Legitimation in Antidiscrimination Law, 101 HARV. L. REV. 1331 (1988) (describing increasing conservative hostility toward civil rights reforms); infra note 82 .

38. See infra notes 81-82 and accompanying text.

39. For recent inquiries into race theory, poverty law and political lawyering practice, see Anthony V. Alfieri, Impoverished Practices, 81 GEO. L.J. 2567 (1993); Angelo N. Ancheta, Community Lawyering, 81 CAL L. REv. 1363 (1993) (reviewing GERALD P. LóPEz, ReBEL lyous Lawyering: One Chicano's Vision of Progressive Law Practice (1992)); Gerald P. López, Reconceiving Civil Rights Practice: Seven Weeks in the Life of a Rebellious Collaboration, 77 GEO. L.J. 1603 (1989); Martha Minow, Breaking the Law: Lawyers and Clients in Struggles for Social Change, 52 PrrT. L. Rev. 723 (1991); William P. Quigley, Reflections of Community Organizers: Lawyering for Empowerment of Community Organizations, 21 Orno N.U. L. Rev. 455 (1994); Conference, Theoretics of Practice: The Integration of Progressive Thought and Action, 43 Hastings L.J. 717 (1992).

40. Neoconservative race theory is often generated by scholars at conservative think tanks such as the Heritage Foundation. See Michael OMI \& Howard Winant, Ractal FORMATION IN THE UNITED STATES 14-23 (2d ed. 1994) (describing neoconservative race theory and its genesis). Over the last decade and a half those scholars have dissected traditional civil rights theory and practice. They now conclude that the civil rights approach to antidiscrimination law is largely illegitimate. Commitments to ending institutional racism and to a methodology of adversariness are not only unnecessary but divisive in a society no longer tolerant of intentional racial discrimination by the bad-hearted. See D'SouzA, supra note 10; Thomas Sowell, CIVIL Rights: Rhetoric or REalrTy? 138-40 (1984). Continuing socio-economic disadvantage for some racial groups is a result of group cultural deficiencies. Prominent neoconservative theorists define racial justice according to notions of colorblindness and equality of process in present-day decisionmaking. See SowelL, supra, at 109; Shelby Steele, The Content of Our Character (1990). These notions form the comerstone of neoconservative political lawyering on race issues. See generally Charles, 
theory and political lawyering practice often seem to connect tenuously at best. ${ }^{41}$ Race theorists, particularly legal race theorists, and political lawyers often seem to operate in separate realms: the former in the realm of ideologies, discursive strategies, and social constructions; the latter in the realm of civil rights statutes, restrictive doctrinal court rulings, messy client management, discovery burdens, and politically conservative judges; ${ }^{42}$ the former in the ethe-

Lawrence, III, The Epidemiology of Color-Blindness: Learning to Think and Talk About Race, Again, 15 B.C. THurd WORLD L.J. 1 (1995) (describing how these ideas translate into arguments against affirmative action). These notions enable neoconservatives to argue against overt racism and in favor of equality while seeking to maintain social structures that subordinate racial minorities. They also undergird organized, frontline, anti-immigrant, antiaffirmative action, and antiwelfare challenges in the courts, universities, legislatures, government bureaucracies, and voting booths. The marriage of theory and practice has given birth to a potent neoconservative race praxis. See OMI \& WINANT, supra, at 128-35; infra note 82.

41. I informally interviewed race scholars, political lawyers, and community activists involved with progressive race work. My account of their responses is impressionistic, and I believe, warrants empirical study. Everyone I talked with agreed that the disjuncture between progressive race theory and political lawyering practice exists. Disagreements centered on its extent, the reasons for it, and what to do about it. The most common explanation for the disjuncture was that the mainstream backlash against justice for racial minorities is so extensive within each person's working realm that day-to-day coping requires all-consuming effort, allowing little opportunity to cross-connect with work in other realms, and thus leaving little time for practitioners to integrate theory and for theorists to do practice.

Explanations offered for relative nonengagement with frontline legal-political activism by theorists include the shopworn - ivory tower academics unconnected with the real world; the extreme postmodern - law is power is politics and resort to legal rhetoric and process are futile; the "lack of experience" thesis - scholars emerging in the Reagan-Bush era generally have little personal experience with large-scale political activism and local community struggles; and the careerism factor - some race scholars may be more interested in building personal careers "using" race than in making a difference for racial communities. Explanations offered for relative nonengagement with progressive race theory by political lawyers include inertia - traditional civil rights litigation is what attomeys are used to; timing most critical theory development has occurred recently, after political lawyers were already "out there"; energy depletion - frontline battles are so energy consuming that there is no space for abstract study; impracticality - the practical payoff of abstract theory study is minimal; and the commodification of civil rights work - litigating civil rights discrimination and harassment claims is a lucrative business now undertaken "as business" by mainstream law firms.

Informal interviews were conducted with William Hoshijo, executive director of $\mathrm{Na}$ Loio No Na Kanaka ("Lawyers for the People") (Asian immigration); Elizabeth Pa Martin, managing attorney of the Native Hawaiian Advisory Council (Hawaiian cultural rights advocacy); Dale Minami, San Francisco civil rights lawyer (lead counsel in the Korematsu v. U.S. coram nobis action); Edward Chen, staff attorney for the Northern California ACLU (English-Only and hate speech); Denise Antolini, former managing attorney for the Hawaii Sierra Club Legal Defense Fund (environmental justice); Charles Ka'ai'ai, Hawaiian Homelands activist; Angela Harris, law professor (race theory and environmental justice); Sherilyn Ifill, law professor and former civil rights litigator (race and civil rights); Francisco Valdes, law professor (race theory and queer theory); Gerald López, law professor and community law clinic supervisor (community antisubordination practice); Marina Hsieh, law professor and former litigator for the NAACP Legal Defense Fund (civil rights and procedure); Mari Matsuda, law professor (race theory and affirmative action); and Julie Su, Staff Attomey for the Asian Pacific American Law Center (community activist and political lawyer).

42. See generally Russell, Revolution, supra note 34 (describing the disconnection between progressive theory and practice); Anthony V. Alfieri, Practicing Community, 107 HaRv. L. ReV. 1747 (1994) (reviewing Gerald P. LOPEZ, Rebellious LAWYERING: ONE 
real realm of postmodern critiques of knowledge and power; 43 the latter in traditional civil rights rhetoric and strategies. 44

This disjuncture appears to be a phenomenon of post-civil rights America. Through the midstages of the civil rights movement, social scientists illuminated the structures and effects of segregation in myriad aspects of social life and theorists offered political movements a rights foundation of integration and equal opportunity. 45 These scholars combined with politicians, activists, and lawyers to challenge apartheid and remake racial justice. Their alliance succeeded in passing antidiscrimination legislation, achieved seemingly favorable judicial decisions, and established antipoverty and affirmative action programs. ${ }^{46}$ Political lawyering practice employed law

Chicano's Vision of Progressive Law Practice (1992)) (noting the lack of practice analysis by critical race and critical legal scholars).

43. For a discussion concerning critical theory and racial justice inquiry, see infra Part III.

44. See Gerald P. López, Rebellyous Lawyering (1993). López identifies the "traditional" civil rights-legal services paradigm of lawyering for social change. Calling it the "regnant" idea of lawyering, he describes a lawyer-centered (client-peripheral) approach to justice issues that is characterized by an emphasis on specific legal outcomes, is animated by legal analysis of case opinions, and searches out clients and contacts community organizations to enhance prospects for favorable legal outcomes. The implicit assumption of this approach is that legal victories gained and favorable precedents established will set in motion change in societal attitudes and institutional structures. See id. at 24. Lopez views this approach as sharply limited for several reasons, including its disempowering lawyer-centered (rather than community-focused) methodology, its overreliance on narrow legal outcomes, and its misperception of the ways in social structural changes occur. See id. at 29.

Kimberle Crenshaw also observes that the traditional civil rights lawyering paradigm, although effective in important respects, rests on largely false assumptions about America's deep-seated commitment to equality and about America's resulting slow but certain march toward racial justice. It also mistakenly assumes the centrality of law and civil rights adjudication (and precedent) in the restructuring of social institutions and government. See Crenshaw, supra note 37, at 1346-47; see also Mari J. Matsuda, The Keynote Address: Progressive Civil Liberties, 3 TEMPLE POL. C.R. L. REv. 9 (1993-94) (distinguishing the "traditional civil liberties approach" from the "progressive civil liberties approach").

45. Social scientists, particularly social psychologists and historians, contributed significantly to a reconceptualization of race itself and the impacts of racial segregation. From physicist Franz Boas (debunking the biological intelligence theory of race) to psychologist John Dollard (identifying settled social patterns producing advantages to whites) to social psychologist Kenneth Clark (describing the negative effects of segregation on student learning), social scientists and theorists played an integral role in the civil rights movement. See RICHARD KLUGER, SIMPLE JUSTICE 308-24 (1977) (describing major contributions of social scientists and race theorists).

46. See KLUGER, supra note 45 (describing civil rights movement struggles and resulting success of the Brown decision in outlawing segregation); William Simon, Visions of Practice in Legal Thought, 36 STAN. L. REv. 468, 499 (1984) (observing how a combination of judicial decisionmaking, electoral politics, and popular mobilization produced civil rights movement successes); see also PaUli Murray, Song IN A WeARY THROAT (1987) (describing law professors working closely with political lawyers in crafting progressive civil rights strategy). 
and newly recognized civil rights in efforts to change government and private institutions. ${ }^{47}$

Since the late 1960s, however, steady attacks on civil rights by neoconservative scholars and politicians undermined legal justice for racial minorities and increasingly constrained progressive lawyering practice. A conservative backlash fueled by the Reagan administration's hostility toward public interest groups and abandonment of antidiscrimination programs threatened gains made by racial minorities. ${ }^{48}$ Lawyers and activists, while rethinking the role of political lawyers and adjusting to practical constraints, struggled within the shrinking confines of the civil rights paradigm. ${ }^{49}$ By contrast, race scholars adopted an increasingly critical posture. They developed sharp critiques, not only of neoconservative race theory and its potent impact on law and politics, but also of liberal legal theory and civil rights law. ${ }^{50}$

Progressive race theorists' many enlightening insights about race, law, and social power, however, tended to reach a limited scholarly audience because those insights were marked by their often difficult translatability into political lawyering and community activism concepts and language..$^{51}$ An emerging reconstructive jurisprudence, discussed below, is beginning to address this difficulty and the disjuncture between high theory and frontline practice. Despite these efforts, however, a recent comment by a political lawyer about progressive race theory ideas and writing is revealing: They are "intriguing but not particularly helpful." 52 They are not particularly helpful to what political lawyers and community groups do in practice when they confront racial oppression within and beyond the courtroom. The comment conveys in other terms the

47. See NAN ARON, Liberty AND Justice for All 3, 85 (1989) (examining the role of public interest groups of the 1960s and 1970s and their use of the courts to protect rights of historically unrepresented groups).

48. See id. at 13-14; see also Crenshaw, supra note 37, at 1337-38.

49. See Aron, supra note 47, at 96 (describing political lawyers' limited strategies beyond use of court system). This expansion, however, has been quite limited. See Alan Freeman, Antidiscrimination Law: The View from 1989, 64 TuL. L. REv. 1407 (1990) (critiquing increasingly constricted civil rights antidiscrimination law paradigm).

50. See infra notes in section III.A.

51. See Raneta Lawson, Critical Race Theory as Praxis: A View From Outside the Outside, 38 How. L.J. 353, 369 (1995) (arguing that the "future of critical race theory is dependent on its ability to expand its [academic] audience base into new spheres of influence, including courts, politicians, the bar and the general public," by addressing "real-world" concerns and transforming theory into practice).

52. Interview with Dale Minami, in San Francisco, Cal. (Oct. 15, 1995). 
commonly expressed concern about the scholarly syndrome of "discourse unto death [such that t] heory begets no practice."53

Margaret Russell brings this disjuncture into sharp relief through her call for a nexus between critical theory and progressive practice. In a review of Crusaders in the Courts, by Jack Greenberg, and Failed Revolutions, by Richard Delgado and Jean Stefancic, ${ }^{54}$ Russell identifies a "gap of chasmic proportions" between Greenberg's endorsement of the traditional civil rights paradigm for social change and Delgado and Stefancic's criticism of contemporary political lawyering practice's failure to undertake critical inquiry. The civil rights paradigm heralded in Crusaders urges political lawyers to "continue the noble crusade" toward a "nonracist, egalitarian society." 55 From this view, progressive practice involves lawyer-centered decisionmaking and the role of lawyer as "everyday hero" in using courts, legal decisions, and litigation to resist and dismantle structures of racial discrimination. ${ }^{56}$

This traditional civil rights law approach to social change, Delgado and Stefancic argue, contributes in the long run to social and political stagnation and even regression. ${ }^{57}$ They assert that the approach encourages a false belief in incremental progress that disguises the profound need for social structural change. ${ }^{58}$ They also connect a lack of social structural change to a failure to "deconstruct the larger structural, institutional, and attitudinal barriers

53. Catharine A. MacKinnon, From Practice to Theory, or What is a White Woman Anyway?, 4 YALE J.L. \& Feminism 13 (1991).

54. See Russell, Revolution, supra note 34 (reviewing JACK GREENBERG, CRUSADERS IN

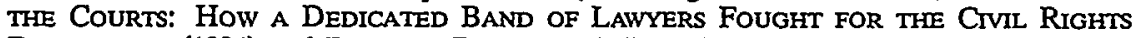
Revolution (1994) and Richard Delgado \& Jean Stefancic, Failed Revolutions: Soctal REForm AND tHE Limits of Legal IMAGINATION (1994)).

55. Id. at 1174 (describing Greenberg's view).

56. See id. supra note 34 , at 1177 . Aron reaffirms the civil rights paradigm even while acknowledging its inadequacy. He recognizes lawyers' attempts to diversify tactics and recruit lobbyists, community organizers, and researchers while observing that "litigation still remains the sine qua non of public interest law." ARON, supra note 47, at 96 . He emphasizes litigation's role in empowering disadvantaged groups, settling disputes fairly, and restructuring public institutions. See id. at 97; see also Cornel West, The Role of Law in Progressive Politics, 43 VAND. L. REV. 1797 (1990) (identifying the deficiencies of existing legal structures while acknowledging the indispensable role of courts for the future of progressive politics). But see Girardeau SPANN, RAcE Against the Court (1993) (discussing how the political lawyer's reliance on the conservative court system hinders acquisition of minority political power). My comments here are not made to disparage the significant achievements of the civil rights movement and are meant only as a critique of the applicability of traditional approaches to contemporary racial conditions.

57. See Richard Delgado \& Jean Stefancic, Failed Revolutions: Social ReFORM AND THE LIMITS OF LEGAL IMAGINATION XV (1994) [hereinafter DELGADO \& Stefancic, FaIled Revolutions].

58. See id. at xvii. 
that insidiously frustrate truly radical reform."59 For Delgado and Stefancic, the solution lies not in heroism but in counterhegemony - in challenging the "influence of legal ideologies and institutions that limit our capacity to imagine and implement radical solutions to society's ills."60

Although progressive theorists such as Delgado and Stefancic raise broad concerns about the limits of traditional civil rights practice, Russell aptly observes that their general suggestions leave unaddressed the ways in which political lawyering can meet contemporary demands of frontline antisubordination practice. ${ }^{61} \mathrm{Rec}-$ ognizing this disconnectedness, Russell calls for a theoretics of practice for progressive scholars and lawyers to "both facilitat[e] social change and understand[] the hidden deterrents to such change."62

The disjuncture is revealed practically in the limited participatory and intellectual presence of progressive race scholars, and particularly legal scholars, in the frontline race-law-politics struggles of the mid-1990s. Those struggles encompass increasing violence against people of color and state legislation and court rulings that incarcerate more African American males for longer periods; 63 Congressional legislation to transform the welfare system; to limit immigration (primarily Latino and Asian), to restrict benefits and rights of legal immigrants, and to require English Only; ${ }^{64} \mathrm{Cali-}$

59. Russell, Revolution, supra note 34, at 1188 (summarizing Delgado and Stefancic's position).

60. Id. at 1175. Delgado and Stefancic ask:

How do lawyers and legal scholars replicate and rehearse old arguments, seldom breaking free to new planes of legal thought and innovation? Why do maverick thinkers find themselves without a community, and how are outsiders marginalized, their voices tamed and silenced?

... How do objective rules and practices favor the more powerful?

Delgado \& Stefancic, Failed Revolutions, supra note 57, at xvi.

61. For instance, Delgado and Stefancic suggest "distrust[ing] the ability of free-market solutions" and "pay[ing] particular attention to what our mavericks and reformers are saying." Delgado \& Stefancic, Failed Revolumions, supra note 57, at 143.

62. Russell, Revolution, supra note 34 , at 1176 . Russell thus asks "what does it mean or could it mean - to combine the theoretical insights of critical race jurisprudence with the conservatizing pressures and demands of everyday public interest practice?" Id. at 1194. This inquiry might encompass how a "postmodernist critique of law reform could or should affect, for example, the micro-level decisions of client representation, choice of impact strategies, lawyer-client interaction, and client autonomy." Id.

63. See Jerry Kang, Note, Racial Violence Against Asian Americans, 106 HARv. L. Rev. 1926 (1993) (describing heightening racial violence); Louis Freedburg, New Jump in Rate of Incarceration of Black Males, SAN FRANCISCO CHRON., Oct. 5, 1995, at A1 (describing legislative and court actions increasing number and duration of Black male incarcerations).

64. See Clinton Will Sign Welfare Overhaul, ChI. Tris., July 31, 1996, § 1, at 1; Frank Wu, Advanced English Only, AsIANWEEK, May 31, 1996, at 11. 
fornia's anti-affirmative action "Civil Rights Initiative";65 and the constitutional challenge to California's anti-immigrant Proposition 187.66 At a recent conference of progressive race scholars, observers worried that those scholars had "become too concerned with the technical jargon of post-modernism" and with matters of little political relevance and that the gathering "was not politicized enough" given its roots in community organizing and the presence of overtly conservative ballot measures and legislation. ${ }^{67}$

The absence of the scholar-lawyer-activist mix is especially notable in two California controversies that raise complex interracial justice issues. In Ho v. San Francisco Unified School District, ${ }^{68}$ discussed at the outset, and United Minorities $v$. San Francisco, ${ }^{69}$ a 1994 Title VII employment discrimination action by African Americans and Latinos in effect charging preferential treatment of Chinese Americans, discussed below, confusion about the interminority issues abounds. The legal claims, racialized rhetoric, and intergroup exchanges, communicated largely through legal filings, news media, and word of mouth, form an interracial morass. Amid this morass, communities of color undermine one another with often thinly veiled insults and proposed settlements that at

65. See supra note 30.

66. See Paul Feldman, Major Portions of Prop. 187 Thrown Out by Federal Judge, L.A. TImEs, Nov. 21, 1995, at A1. There are exceptions to nonengagement. One professor writes a widely read weekly political column for Asianweek. Another testified before a congressional committee against English Only legislation. Others work with community immigration organizations, legal services groups opposing anti-immigrant legislation, and international human rights groups. Others assist environmental justice clinics or participate as litigation consultants concerning housing, employment and indigenous peoples' rights. However, it is my perception, and generally that of those interviewed, see supra note 41 , that direct scholarly participation and engagement in frontline antisubordination practice is the exception rather than the rule. One recent race controversy that has galvanized race scholars involves the Fifth Circuit's decision in Hopwood v. Texas, 78 F.3d 932 (5th Cir. 1996) (ruling University of Texas Law School's race-based affirmative action program unconstitutional despite a long history of intentional racial exclusion at the university and law school). Professors at the first LatCrit Conference in May, 1996, and professor members of the Society of American Law Teachers (SALT) are organizing a variety of legal and political responses to Hopwood. See Correspondence among board members of SALT (on file with author); Interview with Professor Francisco Valdes in San Francisco, Cal. (May 6, 1996). It is noteworthy that at least during the early stages of this scholarly effort the litigation attorneys opposing the plaintiffs in Hopwood appeared to be at most mildly interested in coordinating efforts with progressive scholars. See also Gabriel Chin et al., Beyond Self-Interest: Asian Americans Toward a Community of Justice, 4 UCLA AsIAN PAC. AM. L.J. (forthcoming 1997) (arguments for affirmative action addressed primarily to political activists and the public).

67. Frank Wu, Reclaiming Relevance, AsIANWEEK, June 7, 1996, at 11 (reporting on commentary at the 1996 Asian American Studies Conference in Washington D.C.).

68. See Memorandum Decision and Order, supra note 2.

69. See Third Amended Complaint for Monetary, Declaratory, and Injunctive Relief, United Minorities Against Discrimination v. City and County of San Francisco, No. C-912350 (N.D. Cal. filed Nov. 9, 1994) [hereinafter Third Amended Complaint]. 
best paper over unresolved tensions and satisfy no one. ${ }^{70}$ Group wounds, lying just beneath the surface of daily interactions, and larger intergroup power dynamics go unaddressed. ${ }^{11}$ The critical theoretical work of race scholars offers political lawyers and community leaders insight into the complex race, law, and power dynamics underlying the controversies. ${ }^{72}$ The lawyers and leaders offer race scholars both fertile ground for theory development and opportunities for antisubordination practice. Yet the scholars, lawyers, and community organizations fail to mix in meaningful ways.

Empirical studies on antisubordination lawyering practice highlight the significance of this missed opportunity. The studies address the connections between political power, court issue agendas, and "the role of law and courts as promoters of change."73 More specifically, the studies examine "nondecisions" - the way in which demands for social structural change by disadvantaged groups "can be suffocated before they are even voiced ... or killed before they gain access to the relevant decision-making arena" by established legal and political interests in the local community. ${ }^{74}$ The studies find the integration of community activism with political lawyering efforts essential to an effective countering of established interests. Without a strong alliance between political lawyers and community groups articulating coherent, substantive countermessages and showing political support, court agendas reflect "the prevailing distribution of power in the external environment" in forms "least threatening to powerful interests."75

What scholar-theorists bring to the community-lawyer alliance are critical socio-legal analyses, specific counter-messages, and larger intellectual frameworks for justifying not only legal results

70. See Cany Kit Har Chan, Equitable Admissions: SF Board Revisits a Contentions Admission Policy, AstanweEk, Jan. 26, 1996, at 11 (describing school superintendents' roughly conceived "equality and equity" settlement proposal).

71. See infra Part IV for discussion of specifics.

72. Some of these issues include the manner in which racial categories are formed and acquire social meaning; the ways in which law inscribes and reproduces racialized images and maintains hierarchies among groups; and the ways in which affirmative action discourse by Asian Americans in the past has been appropriated by neoconservative whites. See infra section II.A for further discussion.

73. Mark Kessler, Legal Mobilization for Social Reform: Power and the Politics of Agenda Setting, 24 LAw \& Socy. REv. 121, 126 (1990) (integrating social science studies on the subject).

74. Peter Bachrach \& Morton S. Baratz, Power and Poverty: Theory and PRACTICE 44 (1970).

75. Kessler, supra note 73, at 139; see also GeRALD N. ROSENBERo, The Hollow HOPE: Can Courts Bring About Social Change? (1991). 
but also social structural changes. ${ }^{76}$ Theorists help connect how we think and talk to how we act - a connection at the core of political mobilization. The intellectual fuel for neoconservative activists and politicians provided by scholars at think tanks is evidence of this connection. ${ }^{77}$ The disconnection among progressive race scholars, political lawyers, and community activists is an opportunity missed by those struggling separately against neoconservative race praxis. ${ }^{78}$

Broadly speaking, then, antisubordination practice in post-civil rights America is limited in part by a disjuncture between emergent progressive race theory and frontline civil rights-political lawyering practice. Progressive race scholars, political lawyers, and community activists are rethinking racial justice and struggling toward a common antisubordination goal without coalescing on present-day understandings of, and strategies for, antisubordination practice. As discussed in the next Part, antisubordination practice is further limited by an intensifying dissociation of law from racial justice.

\section{The Dissociation of Law from Racial Justice}

Sociologists find in post-civil rights America two nations divided, separate, hostile, and unequal, ${ }^{79}$ alongside society's "retreat from racial justice." 80 Their findings illuminate both wide disparities in socio-economic conditions between white and nonwhite racial groups ${ }^{81}$ and American society's "retreat" from a commitment

76. See Ruth Margaret Buchanan, Context, Continuity, and Difference in Poverty Law Scholarship, 48 U. MIAMI L. REv. 999 (1994) (describing ways in which poverty lawyering discourses powerfully shape poverty lawyering practice); Margaret M. Russell, Entering Great America: Reflections on Race and the Convergence of Progressive Legal Theory and Practice, 43 HAstings L.J. 749 (1992) (calling for the integration of critical legal theory and lawyering for social change); see also infra note 254 (concerning integration of feminist legal theory with progressive gender practice).

77. See supra note 40 .

78. That opportunity missed spurred the keynote speaker at a recent racial justice conference to comment that conferences and scholarship are important, "[b]ut law professors ... must do more" to engage in "fighting the legal and political battles necessary to effect change." Conference, Race, Law and Justice: The Rehnquist Court and the American Dilemma, 45 AM. U. L. REv. 567, 644 (1996) (from the keynote address by Angela Jordan Davis).

79. See Andrew Hacker, Two Nations: Black and White, Separate, Hostile, UNEQUAL at ix (1995).

80. STEINBERG, supra note 37, at 213.

81. See HACKER, supra note 79. Hacker utilizes statistical studies to illustrate widespread socio-economic inequalities between whites and blacks. According to a 1993 Bureau of the Census study, $46.3 \%$ of African American children are living below the poverty line, compared to $12.3 \%$ of white children. See id. at 105 . Between 1970 and 1992 , black family incomes dropped from $\$ 613$ to $\$ 544$ for every $\$ 1000$ received by white families. See id. at 103 . A 1994 study by the Bureau of Labor Statistics shows that unemployment rates for blacks have not fallen below twice the white unemployment rate since 1976. See id. at 108. Jennifer Hochschild describes an expansion of the black middle class and its continued disenchant- 
to overcome those disparities. ${ }^{82}$ I build upon, but do not repeat, those accounts of racial conditions. I focus in this Part on one aspect of the retreat from racial justice: the dissociation of law (as it conceives of justice) from racial justice (as it is experienced by racialized groups). I highlight three dimensions of this dissociation: first, the law's linkage to racial injustice, or, more specifically, the connection of law and cultural representations to legalized racial oppression; second, antidiscrimination law's failure to address cultural discrimination and institutional racism in ways meaningful to racial minorities and its endorsement of "reverse discrimination" claims; and third, the failure of the bipolar white-black jurisprudential paradigm to handle increasingly complex conflicts and justice claims among communities of color.

\section{A. Law, Cultural Representations, and Racial Oppression}

The United States bears a harsh history of legalized racial oppression. Since the country's inception, law has directly mandated and indirectly supported racial discrimination, degradation, and violence. From the late 1700 s through the $1950 \mathrm{~s}$, racial minorities faced a plethora of overtly hostile constitutional, legislative enactments, judicial rulings, and bureaucratic actions. The Constitution's framers refused to recognize blacks as full citizens and thereby sanctioned slavery. ${ }^{83}$ The first Congress denied nonwhites the op-

ment with the "American dream" due to continuing exposure to racism, alongside persistent impoverishment of the black underclass. See JENNIFER L. HochSCHILD, FACING UP TO THE American Dream: Race, Class, and the Soul of the Nation (1995); see also Paul Brest \& Miranda Oshige, Affirmative Action for Whom?, 47 Stan. L. Rev. 855, 881, 886 (1995) (describing a Census study showing Native American poverty rate to be three times the white rate and Latino poverty rate ranging from two to three times the rate for whites); Clarence Johnson, Racial Gap in Sentences is Growing: New Figures Show Blacks Jailed More, S.F. ChroN., Feb. 13, 1996, at A1 (reporting on a study showing that African American men in California between the ages of twenty and twenty-nine are imprisoned, on parole, or on probation at a rate nearly eight times higher than whites); Poverty Among U.S. Asians Despite Their Affluent Image, S.F. CHRON., May 19, 1994, at A2 (citing a study by LEAP Asian Pacific American Public Policy Institute and the U.C.L.A. Asian American Studies Center showing the Asian American poverty rate to be $50 \%$ higher than the rate for whites).

82. See Streinberg, supra note 37. Steinberg describes the ways in which political retrenchment over the last twenty years has spawned a "scholarship of backlash." He identifies scholars throughout the political spectrum as fueling this backlash, including the far right (attributing socio-economic differences to racial group differences in intelligence), neoconservatives (focusing on perceived cultural inadequacies of the black family rather than structural inequality), left-liberals (emphasizing self-perpetuating pathologies of the African American community) and black neoconservatives (dismissing affirmative action due to its delegitimization of black achievements and reinforcement of black inferiority). This scholarly backlash, which supports political efforts to eliminate welfare and dismantle affirmative action, comes at a time of expanding socio-economic differences between whites and blacks. See also Bert Eljera, Bilingual Voting Under Attack, AsIANwEEK, May 31, 1996, at 8 (describing Congressional Republican assault on bilingual voting ballots).

83. See U.S. Const. art. I, § 2, cl. 3. 
portunity of naturalized citizenship. ${ }^{84}$ Congress later sanctioned the "removal" of Native Americans, annexed the sovereign nation of Hawai' $i$, and excluded Chinese and Japanese immigrants as threats to the economy and public morals. ${ }^{85}$ State legislatures authorized slavery, Jim Crow segregation, the anti-Mexican "Greaser Act," and bans on interracial marriage. ${ }^{86}$ Local law enforcement officers turned a blind eye to the lynching of blacks and Asians. ${ }^{87}$ Governmental bureaucrats prohibited nonwhites from voting and participating in politics and government service. ${ }^{88}$ The California Supreme Court in People v. Hall found the Chinese to be such a "degraded and demoralized caste" as to preclude their testimony against whites. ${ }^{89}$ The United States Supreme Court in Dred Scott declared blacks so inferior in all human respects as to be unworthy of citizenship. ${ }^{90}$ Plessy $v$. Ferguson ${ }^{91}$ declared the equality principle of separate-but-equal, thereby relegating blacks to the back of the bus and the bottom of the racial hierarchy, and Korematsu $v$. United States $^{92}$ upheld the constitutionality of the World War Two internment of Japanese Americans without reliable proof of military necessity. ${ }^{93}$

The in-your-face hostility of these laws and governmental actions is common knowledge. What is less well known are the subtle ways in which racial minorities sometimes experience law's injustice - the ways in which law and cultural representations combine to legitimate racial oppression. Law is more than courts, lawyers, and legal rules. It is an integral part of political-cultural processes that

84. See Naturalization Act of 1790 , ch. $3, \S 1,1$ Stat. 103 (repealed 1795) (restricting admission into the American community to "free white person[s]"). See generally GarY OkIhIro, Margins and Mainstreams: Astans in American History and Culture (1994).

85. See Chinese Exclusion Act, ch. 126, 22 Stat. 58 (repealed 1943); Immigration (Japanese Exclusion) Act of 1924, ch. 190, 43 Stat. 153 (repealed 1952).

86. See Derrick A. Bell, Race, Racism ANd American Law (3d ed. 1992) [hereinafter Bell, Race]; Carl Gutierrez-Jones, Rethinking the Borderlands: Between Chicano Culture and Legal Discourse (1995).

87. See BELL, RACE, supra note 86 , at $289-90$ (stating that post-reconstruction civil rights law failed blacks not only because it was inadequate but because white officials refused to enforce it when blacks most needed legal protection from physical violence).

88. See id.

89. People v. Hall, 4 Cal. 399, 403 (1854).

90. See Scott v. Sandford, 60 U.S. (19 How.) 393 (1856).

91. 163 U.S. 537 (1896).

92. 323 U.S. 214 (1944).

93. See Eric K. Yamamoto, Korematsu Revisited - Correcting the Injustice of Extraordinary Government Excess and Lax Judicial Review: Time for a Better Accommodation of National Security and Civil Liberties, 26 SANTA CLARA L. REV. 1 (1986) [hereinafter Yamamoto, Korematsu Revisited]. 
generate "structures of meaning that radiate throughout social life and serve as part of the material people use to negotiate their understanding of everyday events and relationships."94 Disparaging cultural representations are produced and reproduced through a variety of communicative channels, including law. In terms of constraints on self-definition, law has played a powerful role in imposing identities on racialized minorities as a way of excluding them from full participation in American life. ${ }^{95}$ In terms of constraints on self-development, law has facilitated the destruction of cultural foundations for racial group survival.96

Law's inscription and reproduction of cultural images, which create meaning that "radiates throughout social life," are captured in Arnold Krupat's description of the role of law in the racialization and then "removal" of Indians from eastern America.97 Indian removal, and the destruction of Indian societies, "could finally be written into law and enforced ... because by that time, a certain story about America and about 'civilization' had become sufficiently acceptable [through journalism and literature] that it could be used as ideological justification for 'certain sequences of causes and effects,' for expansion with honor."98 Dominant white government and business powers took prevalent narratives about Indian cultural difference, racial inferiority, and the righteousness of American expansion and inscribed them in a legal text, the Indian

94. David M. Trubek, The Handmaiden's Revenge: On Reading and Using the Newer Sociology of Civil Procedure, 51 LAW \& Contemp. Probs., Autumn 1988, at 111, 124 (1988).

95. According to pseudo-science, people with any African blood, even one drop, were of inferior racial stock and cultural heritage and were therefore appropriately subject to Jim Crow laws prohibiting voting, intermarriage, and first-class schooling, among other things. See Plessy v. Ferguson, 163 U.S. 537 (1896); Doe v. State of Louisiana, 479 So. 2d 369 (1985). According to cultural criteria and "common sense," the courts determined who was "white" and therefore entitled to the benefits of citizenship (Armenians in In re Halladjian, 174 F. 834 (C.C.D. Mass. 1909)) and who was not (Japanese in Ozawa v. United States, 260 U.S. 178 (1922), Chinese in Lum v. Rice, 275 U.S. 78 (1927), and Asian Indians in United States v. Thind, 261 U.S. 204 (1923)). According to blood quantum, Congress determined which Hawaiians would be eligible to receive Homelands parcels ( $50 \%$ or more, labeled "native Hawaiians") and which would not (less than $50 \%$, labeled "Hawaiians"). See Hawaiian Homes Commission Act, 1920, ch. 42 Stat. 108, reprinted in 1 Haw. REV. STAT. 167-205 (Supp. 1989).

96. See Adeno Addis, Individualism, Communitarianism, and the Rights of Ethnic Minorities, 67 Notre DAME L. REv. 615 (1992) (describing dominant society's historical treatment of outsiders in terms of assimilation, exclusion, or negation).

97. See OMI \& WINANT, supra note 40 (describing racialization as political and social processes that ascribe racial meanings to groups or events).

98. See ArNold KruPAT, ETHNocrIticism: EthNOGRAPHY, History, Literature 133 (1992) (examining early Native American federal court cases and the submerged voices of Native American leaders) (quoting ROBERT BERKHOFER, THE WHITE MAN's INDIAN: IMAGES OF THE AMERICAN INDIAN FROM COLUMBUS TO THE PRESENT 145ff (1979) (internal quotation marks omitted)). 
Removal Act. Those narratives legitimated not only the creation of the text but also its coercive enforcement. As if by cloning, the Reagan-appointed Presidential Commission on Indian Reservation Economies later employed nearly identical racialized rhetoric and issued a culturally derogatory report justifying the harsh consequences of decreasing "tribal dependence on federal monies." 99

Like the cultural derogation of African Americans, which was used to justify Jim Crow laws, and the similar denigration of Japanese Americans, which was used to justify mass internment during World War Two, 100 the negation of Native Americans conjoined dehumanizing cultural representations of the racial "other" with legal sanctions.

I am talking not about . . . cold-blooded atrocities but about law and the ways in which [cultural] genocidal objectives have been carried out under color of law . . . "legally, philanthropically, without shedding blood, and without violating a single great principle of morality in the eyes of the world." These were legally enacted policies whereby a way of life, a culture, was deliberately obliterated. ${ }^{101}$

As Krupat again observes, laws are not merely public texts but "publicly sanctioned texts," and "their language does not merely express or represent but effectually permits, prohibits, or requires particular acts." Legal texts thus not only persuade, they coerce. They are "enforced by the full power of the state."102 What Krupat and others describe is the oppressive way law sometimes operates as a discursive strategy backed by force. It starts with the assessments of cultural difference and the marking of inferiority upon the racialized minority. It then inscribes an inferior identity into a legal text - defining Indians as wards of the government - that then legitimates paternalism - requiring Indian acceptance of the

99. See Robert A. Williams, Jr., Documents of Barbarism: The Contemporary Legacy of European Racism and Colonialism in the Narrative Traditions of Federal Indian Law, 31 ARIZ. L. Rev. 237, 266 (1989) (quoting REPORT AND ReCOMMENDATIONS OF THE PRESIDENtial Commission on Indian Reservation ECONOMies, at pt. I, 7 (1984)).

100. See Hirabayashi v. United States, 320 U.S. 81 (1943) (invoking cultural stereotypes to infer Japanese American disloyalty); Korematsu v. United States, 323 U.S. 214 (1944) (relying on Hirabayashi in sustaining military's conclusion of potential Japanese American threat justifying mass exclusion and intermment); BELI, RACE, supra note 86 (describing the use of cultural derogation of African Americans to justify harsh legal treatment); see also Yamamoto, Korematsu Revisited, supra note 93.

101. Rennard Strickland, Genocide-at-law: An Historic and Contemporary View of the Native American Experience, 34 KAN. L. Rev. 713, 719 (1986) (quoting 1 AleXIS DE TOCQUEVILLE, DemocraCY IN AMERICA 355 (H. Reeve trans., Alfred A. Knopf 1945) (1836)).

102. See KRUPAT, supra note 98 , at 130. 
subordinated identity of "dependent sovereign" - or negation removal. ${ }^{103}$

In this manner, law operates as a "cultural system that structures relationships throughout society, not just those that come before courts."104 As a cultural system, law sometimes inscribes and reproduces liberatory ideas and group images. Often, however, it reflects dominant interests and fosters structural "oppression less by coercion than by offering people identities contingent upon their acceptance of oppression as defining characteristics of their very selves."105 Law is experienced in this fashion by racial minorities as injustice, not because of any particular hostile legislative enactment or court ruling, but because of the systemic oppression it legitimates.

\section{B. Limits of Antidiscrimination Law}

Justice, or perceptions of justice, is also tied to law. Both political and popular culture refer to the legal system as "the system of justice." Americans think of substantive justice as what juries find and judges declare, and procedural justice as fairness in the process of adjudication. ${ }^{106}$

Many Americans still think of racial justice in terms of law more specifically, in terms of government and private enforcement of antidiscrimination constitutional provisions and statutes designed to proscribe white discrimination against blacks. The Fifth and Fourteenth Amendments to the Constitution, ${ }^{107}$ the Civil Rights Acts of 1877 and 1964, ${ }^{108}$ the Voting Rights Acts, ${ }^{109}$ the Fair Housing Act, ${ }^{110}$ Brown v. Board of Education, ${ }^{111}$ Shelley v. Kraemer, ${ }^{112}$

103. See Albert Memmi, The Colonizer and the Colonized (Howard Greenfeld trans., 1965) (describing racism in these terms).

104. Guyora Binder, Beyond Criticism, 55 U. Cm. L. REv. 888, 889 (1988).

105. $I d$.

106. See E. Allan Lind \& Tom R. Tyler, The Soctal Psychology of Procedural Justice (1988); Laurens Walker et al., The Relation Between Procedural and Distributive Justice, 65 VA. L. REV. 1401 (1979).

107. U.S. Const. amend. V; U.S. Const. amend. XIV.

108. Civil Rights Act of 1866, ch. 31, $\$ 1,14$ Stat. 27; Civil Rights Act of 1964, 42 U.S.C. $\S \S 2000 \mathrm{a}-2000 \mathrm{~h}$ (1994).

109. Voting Rights Act of 1965, 42 U.S.C. $\$ \$ 1973-1973 b b$ (1965).

110. Fair Housing Act of 1968, 42 U.S.C. $\$ \S 3601-3619$ (1979 \& Supp. IV 1981) (also known as Title VIII).

111. 347 U.S. 483 (1954) (overruling Plessy and rejecting separate-but-equal formulation of equality for African Americans).

112. 334 U.S. 1 (1948) (holding racially restrictive covenant in land deed unconstitutional). 
and Loving $v$. Virginia, ${ }^{113}$ among other things, form an edifice of modern antidiscrimination law. The African American civil rights movement of the 1950s and 1960s placed antidiscrimination law at the center of its political and moral strategies, 114 and in some important respects those strategies succeeded. Over time, antidiscrimination laws compelled the state and federal governments to bring their considerable powers to bear in prohibiting intentional race discrimination in the public realm. ${ }^{115}$ Overt racism by whites against blacks was, and continues to be, largely delegitimized by this law-centered, intentionalist approach to racial justice. Many people, including racial minorities, celebrate this approach and lift it up as a model for democratic societies. ${ }^{116}$

For others, however, antidiscrimination law and the civil rights paradigm are sharply limited. Over the last fifteen years, court decisions interpreting and applying antidiscrimination laws, primarily in white-on-black settings, have tended to define racial justice in crabbed and inverted ways. ${ }^{117}$ Those decisions and recent procedural reforms conceive of and administer justice in ways that clash

113. 388 U.S. 1 (1967) (holding state antimiscegenation laws unconstitutional).'

114. See generally ARON, supra note 47 (describing civil rights attomeys' reliance on litigation to further the interests of underrepresented groups); GREENBERG, supra note 54 (describing the role of NAACP Legal Defense Fund's lawyers in the movement toward racial justice through law); Anthony E. Cook, Beyond Critical Legal Studies: The Reconstructive Theology of Dr. Martin Luther King, Jr., 103 HARv. L. REv. 985 (1990) (describing law as part of the political and moral strategies of the civil rights movement).

115. See generally BELL, RACE, supra note 86 (describing antidiscrimination legislation and its effect on race discrimination).

116. See Eric K. Yamamoto, Friend, Foe or Something Else: Social Meanings of Redress and Reparations, 20 DEN. J. INTL. L. \& POLY. 223 (1992) (critiquing those who hold up American civil rights laws as a model for democratic societies).

117. Constitutional equal protection and Title VII analyses tend to narrowly define racial discrimination as unequal treatment on the basis of "skin color," to focus on intentional wrongdoing, and to see racial harm as suffered by individuals rather than groups. See ANgela Harris, What We Talk About When We Talk About Race (forthcoming 1997) [hereinafter HARRIS, TALK ABOUT RACE]. Culture-based discrimination and acts of unconscious racism by governmental and private sector actors are ignored. See id. Discrimination that is systemically maintained in business, education, and housing lies beyond antidiscrimination law's reach. See Charies Lawrence III, The Id, the Ego, and Equal Protection: Reckoning with Unconscious Racism, 39 STAN. L. REv. 317 (1987) [hereinafter Lawrence, Unconscious Racism]. Moreover, the legal requirement of direct causation - proof that the wrongful act directly resulted in specific, redressable harm - undermines most historically rooted group claims for justice. See Lujan v. National Wildlife Federation, 497 U.S. 871 (1990). Even when actionable discrimination is proven, race conscious remedies are narrowly drawn by balancing the interests of harmed racial group members and "innocent" whites. See Martin v. Wilks, 490 U.S. 755 (1989) (holding that nonparties to consent decree may bring collateral challenges). With these interests in mind, the Court's de facto embrace of colorblindness permits white claims of "reverse discrimination." See Bush v. Vera, $116 \mathrm{~S}$. Ct. 1941 (1996); Shaw v. Hunt, 116 S. Ct. 1894 (1996) [hereinafter Shaw II]; Adarand Constructors, Inc. v. Pena, 115 S. Ct. 2097 (1995); Shaw v. Reno, 509 U.S. 630 (1993) [hereinafter Shaw I]; City of Richmond v. J.A. Croson Co., 488 U.S. 469 (1989). 
with the ideals, perceptions, and concrete experiences of many members of racial communities, thereby dissociating law (not completely, but significantly) from racial justice. 118

While political lawyers struggle to cope with the practical ramifications of this dissociation - constricted substantive claims, inhospitable procedures, impatient judges, frustrated clients progressive race scholars critically search for explanations. Five explanations developed by theorists warrant brief mention. The first is that even the Court's "progressive" antidiscrimination rulings reflect majoritarian interests. From this view, law and legal process tend primarily to preserve the social and political status quo, ${ }^{119}$ and thus antidiscrimination law generates illusions of systemic reordering and long-term racial justice. Society perceives the declaration and occasional enforcement of intentionalist antidiscrimination laws as justice done. ${ }^{120}$ This perception enables society's majority to believe in equality while ignoring the limitations of legal justice and the persistence of institutional racism.

Citing Brown v. Board of Education ${ }^{121}$ and advancing an interest-convergence thesis, Derrick Bell argues that under law, material

118. See SPANN, supra note 56 (describing conservative substantive rulings by the Supreme Court). In addition to substantive rulings, procedural reforms diminish court access, particularly for those on society's margins. See Eric K. Yamamoto, Efficiency's Threat to the Value of Accessible Courts for Minorities, 26 HARv. C.R.-C.L. L. REv. 341 (1990) [hereinafter Yamamoto, Efficiency's Threat]. Moreover, even when "disadvantaged groups [have] access to authoritative decisionmakers," unless effectively countered, dominant legal and political interests in the local community implicitly threaten political lawyers and employ judicial procedures to transform broad group or class issues into individualized disputes "in forms that are least threatening to powerful interests." Kessler, supra note 73, at 139. Kessler's study identified "five major mechanisms sustaining [dominant] legal community norms against litigating reform issues." Id. at 132. Those included the imposition of sanctions, the explicit threat of sanctions, criticism about professionalism that carried implicit threats about future opportunities, and the application of "negative labels." See id. The study found that the one instance in which conservative interests (bar association, judiciary) were ineffective in deploying those mechanisms involved an urban legal services organization that allied itself with many well-organized community groups with political connections. See id. at 136.

119. See Delgado \& Stefancic, Failed Revolutions, supra note 57 (describing how the methods and structure of legal justice operate to preserve unequal status quo social arrangements while persuading society, including traditional civil rights lawyers, of continuing social progress). Related critiques of law and legal process have been made since the turn of the last century. Those critiques in varying ways challenge the presumed neutrality and objectivity of legal rules in their formulation, interpretation, and application; interrogate legal methods in terms of power, and value and examine the operation and social effects of the legal system. See generally Karl Llewellyn, JuRISPRUdence: Realism IN TheORY AND PRACIICE 11 (1960) (legal realism); Catherine MacKinnon, Feminism, Marxism, and the State, Toward a Feminist Jurisprudence, 8 Signs 635 (1983) (feminist legal theory); Gary Peller, The Metaphysics of American Law, 73 CAL. L. REv. 1151 (1985) (critical legal studies); Roscoe Pound, The Scope and Purpose of Sociological Jurisprudence, 25 HARV. L. REv. 489 (1912) (sociological jurisprudence); infra Part III (critical race theory).

120. See Derrick Bell, FAces at the Bottom of the Well (1992).

121. 347 U.S. 483 (1954). 
progress for racial minorities is allowed by law creators and decisionmakers only to the extent that the progress also furthers the political and economic interests of predominantly white institutions. $^{122}$ Interest-convergence explains why some racial minorities perceive that the "legal establishment has not responded to civil rights claims that threaten the superior societal status of upper and middle class whites."123 From this perspective, rather than protecting the liberties and interests of minorities, the Court has tended to reflect conservative majoritarian values and political preferences. ${ }^{124}$

A second explanation is courts' increasingly narrow understanding of what race, and therefore racial discrimination, is. For a majority of the current Supreme Court, race is skin color. Race is thus seen as an immutable, biologically determined trait. Racism, in turn, is the "belief, held by too many for too much of our history, that individuals should be judged by the color of their skin"125 prejudice about something beyond anyone's control and irrelevant to human interactions. In short, color discrimination is wrong; antidiscrimination law prohibits it. By contrast, culture - language, accent, customs - is seen as changeable, socially created, and voluntarily adopted. It is seen as separate from race. Culture discrimi-

122. See Derrick A. Bell, Jr., Brown y. Board of Education and the Interest Convergence Dilemma, 93 HARv. L. REv. 518 (1980) [hereinafter Bell, Interest Convergence]. Brown, the historic desegregation case, is widely acclaimed as a civil rights victory for African Americans. Bell perceives the Court's decision to have been primarily motivated by concern about the United States' standing to fight the Cold War against Soviet communism. See id. at 524; BELL, RACE, supra note 86. The United States could not promote democracy internationally if apartheid continued in America. The Court therefore renounced its own separate-butequal framing of the principle of equality. For Bell, the Court stated a strong principle to further its international interests' and then winked at domestic enforcement. The Court's weak remedial mandate revealed its lack of commitment to ending racial subordination at home. That mandate allowed states to maintain segregation provided they appeared to be moving toward integration with "all deliberate speed." See Brown v. Board of Education, 349 U.S. 294, 301 (1955) (instructing state governments and federal courts to proceed to remedy school segregation with "all deliberate speed."). That minimal antidiscrimination mandate "engendered increasingly protracted battles with social and political forces that defiantly resisted court-ordered integration." Cheryl Harris, Whiteness As Property, 106 Harv. L. REv. 1709, 1755 (1993); see also Mark Tushnet, What Really Happened in Brown v. Board of Education, 91 Colum. L. REv. 1867, 1867 (1991) ("[The] Supreme Court endorsed a formula of gradual desegregation that provided the opportunity for massive resistance in the Deep South and for token desegregation elsewhere.").

123. Lawrence, Unconscious Racism, supra note 117, at 122.

124. One observation about the Rehnquist Court is that it simply has undertaken correctives to perceived political imbalances, that the Court has responded to complaints that discrimination suits against whites and affirmative action for women and racial minorities have divided the American polity and have unfairly disadvantaged those in the majority. If the Court has undertaken these majoritarian "correctives," Girardeau Spann aptly observes, then the traditional and still prevalent notion of the judiciary as the last bastion of protection of minorities against intemperate majorities belies actual practice. See SPANN, supra note 56, at $19,129$.

125. Shaw I, 509 U.S. at 657. 
nation is not necessarily wrong and may even be rational; antidiscrimination law allows it.

As discussed above, however, color and culture are inextricably intertwined. ${ }^{126}$ When we talk about race in the United States we are talking not just about skin color but also about the cultural shape and content of our polity. Color and culture, intertwined, influence who gets in (immigration), who participates politically (electoral districting and multilingual ballots), who gets incarcerated (three strikes and you're out), what languages are spoken (English Only legislation), what customs are allowed (housing arrangements, spiritual practices), how educational and job opportunities are parceled out (slotting according to "cultural traits"), and how social services are delivered (medical care, welfare). Designations of cultural difference are used effectively by some in dominant power positions to justify excluding racialized groups from the polity. As Angela Harris observes, limiting antidiscrimination law's reach solely to color prejudice permits "discrimination against traditionally subordinated groups, so long as it is recharacterized as being based on 'culture' rather than 'race." "127

A third explanation for the dissociation of antidiscrimination law from racial justice concerns the law's internal methodological constraints. ${ }^{128}$ Cass Sunstein locates one such constraint in the notion of "commensurability."129 Substantive and remedial legal doctrine often treat as commensurable things that the people involved would adjudge incommensurable. Law does this "in part by creating categories that abstract away some of the very aspects of a given dispute that ... 'are of greatest significance to the parties themselves." "130 In a given dispute, what may be "incomparable,' and therefore . . . irresolvable by a 'rational choice' . . . to the parties themselves, may nevertheless be, from the perspective of the law, resolved in a principled manner."131 One consequence is a legal

126. See Harris, TALK ABout Race, supra note 117.

127. Id.

128. See generally Jack M. Beermann, A Critical Approach to Section 1983 with Special Attention to Sources of Law, 42 STAN. L. REv. 51 (1989) (critiquing the internal methodological failings of civil rights law).

129. See Cass R. Sunstein, Incommensurability and Valuation in Law, 92 Mrch. L. REv. 779 (1994).

130. David B. Wilkins, Practical Wisdom for Practicing Lawyers: Separating Ideals from Ideology in Legal Ethics, 108 HARV. L. REv. 458, 471 (1994) (reviewing and quoting ANTHONY T. KRonman, The Lost LaWyer: FaIling Ideals of the Legal Profession 57 (1993) (critiquing Sunstein's view of commensurability in law)); see also Steven Winter, Indeterminacy and Incommensurability in Constitutional Law, 78 CAL. L. REV. 1441 (1990).

131. Wilkins, supra note 130, at 471; see also ANTHONY T. KRONMAN, THE LOST LaWYER: Failing IDEALS OF tHe Legal PROFEssion 17-23 (1993). 
system designed to resolve disputes in a principled manner, the results of which, by definition, constitute justice. Another consequence is that what this system defines as just and rational, based on the principle of commensurability, may be experienced in the material world as unjust and irrational by those directly affected.

An expansive notion of commensurability in cases of intentional institutional racism, for example, limits the range of meaningful remedies. It deems commensurate the harm of intentional institutional racial harassment and a specified amount of money, even though a monetary award may not redress human indignity, alter relationships, or restructure offending institutions ${ }^{132}$-a principled rendering of legal justice often deemed unjust by those suffering the racial harm.

A fourth explanation involves a procedural realism attentive to questions of power and value. I have written elsewhere about how recent efficiency reforms in the law's adjudicatory procedures and the narrowing of remedial options tend to diminish court access for those already at society's margins, especially racial and other minorities asserting novel claims or theories that challenge existing social and political arrangements. ${ }^{133}$ Critical sociological proceduralists observe ways in which procedural rules and systems, in formulation, interpretation, and application, often reflect socalled substantive value choices. ${ }^{134}$ The collapse of the clean substance-procedure dichotomy implicates power allocation and political value judgments in the framing and handling of adjudicatory process. ${ }^{135}$ These theoretical observations are buttressed by empiri-

132. Courts generally are reluctant to grant injunctive relief if monetary damages are awardable. 11A Charles Alan Wright et al., Federal Practice and Procedure $\$ 2944$ (2d ed. 1995). Because monetary damages are awardable for most wrongs under the notion of commensurability, injunctive and other forms of equitable relief are often disallowed.

133. See Yamamoto, Efficiency's Threat, supra note 118.

134. See, e.g., Stephen N. Subrin, How Equity Conquered Common Law: The Federal Rules of Civil Procedure in Historical Perspective, 135 U. PA. L. Rev. 909 (1987); Carl Tobias, The Transformation of Trans-Substantivity, 49 WASH. \& LEE L. REv. 1501 (1992); Trubek, supra note 94; Yamamoto, Efficiency's Threat, supra note 118; Stephen B. Burbank, The Costs of Complexity, 85 Mich. L. Rev. 1463 (1987) (reviewing RICHARd L. MARCUS \& EDWard F. SHerman, Complex Litigation: Cases and Materials on AdVANCEd Civil Procedure (1995)); William N. Eskridge, Jr., Metaprocedure, 98 YALE L.J. 945 (1989) (reviewing Robert M. COVER ET AL., PROCEDURE (1988)); Bryant G. Garth, Privatization and the New Formalism: Making the Courts Safe for Bureaucracy, 1988 LaW \& Soc. INQ. 157 (1988) (reviewing Richard A. Posner, THE Federal Courts: Crisis aNd Reform (1985)).

135. See generally Eric K. Yamamoto \& Joseph L. Dwight IV, Procedural Politics and Federal Rule 26: Opting-Out of "Mandatory" Disclosure, 16 U. HAW. L. REv. 167 (1994). 
cal studies of court access for disadvantaged groups seeking social structural change through law. The studies identify

the ways in which dominant interests exclude from government [justice] agenda issues that threaten the status quo [by the use of] ... "a set of predominant values, beliefs, rituals, and institutional procedures ('rules of the game') that operate systematically and consistently to the benefit of certain persons and groups at the expense of others."136

As procedural justice research confirms, these kinds of racial minority experiences with legal process, the system's procedures and methods, are likely to influence strongly minorities' overall perceptions of the limitations of legal justice. ${ }^{137}$

A final explanation for the limits of antidiscrimination law for racial minorities locates critiques of majoritarian influence, race definitions, internal methodology, and procedural reform in a specific political context. The Reagan-Bush federal judiciary, appointed in the 1980 s, reflects a conservative race ideology. ${ }^{138}$ More than furthering majoritarian interests, the courts' recent rulings reveal antiracial minority sentiments. This is not surprising given that President Reagan's Attorney General, Edwin Meese, made political conservatism on race issues, among others, a precondition of appointment to the bench. 139 In the mid-1990s, for instance, the Court effectively dismantled federal race-based affirmative action programs, 140 invalidated on equal protection grounds voter redistricting plans (African American- and Latino-majority districts) in North Carolina and Texas, ${ }^{141}$ and ended, in practical effect, a school

136. Kessler, supra note 73, at 125 (quoting BACHRACH \& BARATz, supra note 74, at 43 ).

137. See LIND \& TYLER, supra note 106, at $61-92$ (social psychology of procedural justice).

138. Although the Court has exhibited centrist tendencies concerning gender, see United States v. Virginia, 64 U.S.L.W. 4638 (1996); Casey v. Planned Parenthood, 510 U.S. 1309 (1994), and sexual orientation issues, see Romer v. Evans, 116 S. Ct. 1620 (1996), the Court's majority has consistently ruled conservatively in the realm of race. See infra text accompanying notes $\mathbf{1 8 8 - 2 0 0 .}$

139. See Herman Schwartz, Packing the Courts: The Conservative Campaign to Rewrite tre Constitution (1988); Timothy B. Tomasi \& Jess A. Velona, Note, All the President's Men?: A Study of Ronald Reagan's Appointments to the U.S. Courts of Appeals, 87 COLUM. L. REv. 766 (1987); see generally Brian K. Landsberg, Race and the Rehnquist Court, 66 Tul. L. Rev. 1267 (1992).

140. See Adarand Constructors, Inc. v. Pena, 115 S. Ct. 2097 (1995).

141. See Bush v. Vera, 116 S. Ct. 1941 (1996); Shaw II, 116 S. Ct. 1894 (1996); Miller v. Johnson, 115 S. Ct. 2475 (1995). In attempts to comply with the Voting Rights Act of 1965 , North Carolina in Shaw II and Texas in Bush created irregularly shaped majority African American and Hispanic congressional districts. Chief Justice Rehnquist's opinion in Shaw appeared to recognize a new right to "colorblind" districting. Justice Stevens in his dissent argued that the Court's decision to entertain the plaintiffs' claim emanated 'less from the Equal Protection Clause's bar against racial discrimination than from the Court's unarticulated recognition of a new substantive due process right to 'color-blind' districting itself." 
racial desegregation effort. ${ }^{142}$ In several of these cases the Court's majority embraced a form of constitutional colorblindness to protect whites against affirmative governmental actions favoring nonwhites.

In sum, for many racial minorities, Bell's interest-convergence thesis resonates: racial progress under law appears to be influenced largely by the majoritarian interests of white Americans. Harris's observation about the law's limiting conception of racial discrimination as color prejudice illuminates: race-connected claims of culture subordination are deemed nonjusticiable. Sunstein's notion of commensurability reveals dissonance: what the legal system defines as racial justice according to abstract principles may not reflect the perceptions and concrete experiences of racial communities. Procedural realism undercuts the notion of the inherent neutrality of court procedures: racial and other minorities are finding a reformed procedural system increasingly inhospitable to their justice grievances. Critical contextual analysis reveals conservative racial policies embedded in law: a belief by decisionmakers that racial minorities have gotten more than their fair share at the expense of "innocent whites."

The limitations of antidiscrimination law, identified by theorists, coalesce practically for many racial minorities in an experience of law as often irrational, as a "retreat from racial justice."143 A recent survey for the California Judicial Council found that a majority of African Americans and Latinos believe that the courts do not ensure racial fairness. ${ }^{144}$ Professor and attorney Linda Krieger describes her racial minority clients after "encounters with civil rights enforcement" as "embittered," "frustrated and misunderstood."145

For progressive race theorists and political lawyers, justice through antidiscrimination law thus is a conundrum. Hope, prom-

Shaw II, 116 S. Ct. at 1910. In both cases, the Court declared that an interest in ameliorating past discrimination did not justify the use of race in the redistricting plans.

142. See Missouri v. Jenkins, 115 S. Ct. 2038 (1995).

143. STEINBERG, supra note 37. Steinberg's study addresses many aspects of American society's "retreat" from racial justice, of which civil rights law enforcement is one. $C f$. George M. Fredrickson, Far From the Promised Land, N.Y. Rev. of Books, Apr. 18, 1996, at 18-19 (criticizing Steinberg's apparent view that the only racial justice paths are either full governmental intervention or racial minority self-help and that the former is the only choice because the latter is precluded by systemic discrimination).

144. See Bert Eljera, APAs and the Law: Trial By Fire, AsIANweek, June 7, 1996, at 12, 14 (citing a 1992 study by the advisory panel to the California Judicial Council).

145. Linda Hamilton Krieger, The Content of Our Categories: A Cognitive Bias Approach to Discrimination and Equal Protection Employment Opportunity, 47 STAN. L. REv. 1161, 1164, 1166 (1995). 
ise, and change are its legacy, ${ }^{146}$ as are disillusionment, breach, and stasis. My point is not that legal justice is impossible for racial minorities in post-civil rights America. Indeed, many continue to lobby local legislatures and file discrimination lawsuits; some achieve personal relief, and a few compel institutional reordering. ${ }^{147}$ My point is that in concept and in current practice the civil rights, antidiscrimination law approach to racial justice is sharply constricted and that for many racial minorities this constriction undermines the notion of justice through legal process. It pulls law away from racial justice.

\section{Limits of the White-on-Black Paradigm: Jurisprudential Blindness to Color on Color}

As America becomes a nation of many minorities rather than a nation of black and white, the assumption that rights and especially remedies crafted for a biracial society will fit a multiracial one becomes increasingly problematic. ${ }^{148}$

The preceding section described antidiscrimination law in the context of white on black relations. As intimated by the epigraph above, this legal framing of race controversies tends to dissociate law from racial justice in another important respect. The prevailing white-black jurisprudential paradigm narrowly conceives race relations in post-civil rights America: white versus black, majority versus minority, perpetrator versus victim. ${ }^{149}$ This conception is limiting in two ways: It limits racial inquiry to white and black relations, and its binary oppositional framing of race issues generates an either-or view of racial justice. While white on black disputes are of immense continuing import, the white-black casting of race issues misses important complexities in multiracial America.

The inadequacy of the white-black paradigm is revealed in its marginalization of issues of inter-minority-group, or interracial, justice. ${ }^{150}$ The Supreme Court, as part of its antidiscrimination law,

146. See supra notes $107-15$ and infra note 147 .

147. See, e.g., Vietnamese Fishermen's Assn. v. Ku Klux Klan, 518 F. Supp. 993 (S.D. Tex. 1981) (enjoining Ku Klux Klan and white fishermen from harassing legal immigrant Vietnamese fishermen). For a discussion of ways in which legal process and rights claims contribute to group empowerment within broad political strategies, see infra Part IV.

148. HARRIS, TALK ABOUT RACE, supra note 117.

149. See Elizabeth Martinez, Beyond Black/White: The Racisms of Our Time, 20 Soc. Just. 22 (1993); Eric K. Yamamoto, Rethinking Alliances: Agency, Responsibility and Interracial Justice, 3 UCLA AsIAN PAC. AM. L.J. 33 (1995) [hereinafter Yamamoto, Rethinking Alliances].

150. It also overlooks white relations with nonblack people of color. While this relationship is also jurisprudentially important, see, for example, Hernandez v. New York, 500 U.S. 
has not addressed meaningfully the dynamics of conflict among racial minorities, nor has it developed a framework for analyzing interminority justice claims. ${ }^{151}$ Similarly, until recently, legal scholars largely have ignored this aspect of racial justice. ${ }^{152}$

While white on black and white on color relationships are integral to every discussion of racial justice, color on color relationships are also salient. ${ }^{153}$ Conflicts among racial minority groups, and attempts to forge alliances out of conflict, are increasingly prevalent.154 The Asian American churches' resolution of apology and redress to Native Hawaiians, ${ }^{155}$ the African American, Latino, and Asian American coalitional efforts following the Rodney King police trial firestorm in Los Angeles, and the Chinese American challenge to affirmative action for blacks and Latinos in San Francisco's public high schools in $H o$ are recent situations raising volatile, highly publicized issues of interracial justice.

Social and political scientists, anthropologists, economists, ethnic studies scholars, and peace scholars are pursuing the changing dynamics of these kinds of intergroup conflicts in post-civil rights America. ${ }^{156}$ Their diverse works offer two particularly compelling

352 (1991), in which a white attorney was permitted to use peremptory challenges to eliminate Hispanic jurors. I focus on interminority group, or interracial, relations.

I use the term "interracial" narrowly to mean interactions between members of two or more nonwhite racial groups. In doing so I acknowledge the social construction of racial categories, see OMI \& WNANT, supra note 40 , and the significance of white as a racial category, see Ian F. Haney Lopez, White by Law: The Legal Construction of Race (1996)). I define interracial justice in the following fashion:

Interracial justice ... reflects a commitment to anti-subordination among nonwhite racial groups. It entails in substance a hard acknowledgment of ways in which racial groups have harmed and continue to harm one another, sometimes through forms of oppression, along with affirmative efforts to redress past harms with continuing effects.

Yamamoto, Rethinking Alliances, supra note 149, at 34. I recognize that discussion of interracial justice, which addresses how nonwhite racial groups sometimes oppress one another, can easily be taken out of context and misused.

[I]n light of current anti-affirmative action initiatives, the discussion can be misused to absolve whites of responsibility for continuing structural subordination of racial groups and to recast whites as primary "victims" of racism.... [The] discussion of interracial conflict, even as a predicate to interracial healing, [also] can be misused simply to highlight divisions among racial groups.

Id. at 71 .

151. See Natapoff, supra note 26.

152. See infra note 156 (describing recent legal scholarly treatment of interminority conflict).

153. See Yamamoto, Rethinking Alliances, supra note 149, at 34-39.

154. See infra notes $156-57$ and accompanying text.

155. See Yamamoto, Rethinking Alliances, supra note 149, at 39 (describing Asian American churches' proposed apology to and reparations for Native Hawaiians as a result of Asian American complicity in the cultural and economic subordination of Hawaiians following the overthrow of the Hawaiian nation in 1893).

156. Within the United States, these scholars address conflicts between citizens and immigrants tied to racial demographic shifts, economic changes, and nativistic responses, see BILL 
insights. ${ }^{157}$ The first is heuristic: Interminority group competition and conflict can be studied and understood only by locating it within the larger context of historical white domination and its continuing effects. Contemporary interracial relations are framed, at least in part, by the historical and present-day political, economic, and social power of whites in America. ${ }^{158}$ The second, and related, insight is descriptive: Relations among racial minority groups are qualitatively different from relations between whites and blacks. Due to each racial group's differing historical experiences with white dominance, due to the dynamics of current "group positioning" along a shifting, but nevertheless extant, racial hierarchy, and due to cultural diversity and differing socio-economic conditions,

Ong Hing, Making and Remaking Asian america Through Immigration Policy 1850-1990, at 2, 9-10 (1993), present-day tensions and reparatory efforts involving America's indigenous peoples and nonwhite groups, see WrLl KYMLICKA, MulTiCultural Citizen. SHIP: A LIBERAL THEORY OF MinORITY Rights (1995) (focusing on American and Canadian Indians) and, within a context of continuing white dominance, "group positioning" along a "racialized" hierarchy involving Asian Americans, Latino Americans, African Americans, and Native Americans. See Almaguer, supra note 6. Most notably, a variety of socio-political works interrogate inner-city African American and Korean American cultural misunderstandings, conflict, and violence - inquiries spurred in the early nineties by the South Central Los Angeles firestorm, the "Red Apple" African American boycott of Korean merchants in Brooklyn, the Ice Cube rap "Black Korea," and the Soon Ja Du shooting of Latasha Harlins. See, e.g., Los Angeles - Struggles Toward Multiethnic Community, 19 AMERASIA J. (1993) (entire volume examining conflictual relations among African Americans, Asian Americans, and Latino Americans).

157. These works suggest a range of explanations for interracial confict in post-civil rights America. Sociological explanations tend to focus on assimilation (the difficulties experienced by newcomers in terms of a pattem of contact, conflict, accommodation, and $\mathrm{f}$ nally, integration) or on socio-economic dislocation (the involuntary movement of social groups, and particulariy African Americans, as a result of Latino and Asian immigration and a restructured economy). See William Julius Wilson, The Truly Disadvantaged: The InNer CITY, the Underclass, and Public Policy 20 (1987); James H. Johnson, Jr. \& Melvin L. Oliver, Interethnic Minority Conflict in Urban America: The Effects of Economic and Social Dislocations, in RACE AND ETHNic Conflict 194 (Fred L. Pincus \& Howard J. Ehrlich eds., 1994). Economic analyses tend to describe race-class hierarchies with wealthy and middle class whites at the top, poor African Americans and Native Americans at the bottom, and working class whites and recent minority immigrants in the middle. These analyses discuss intergroup tensions in terms of labor competition among racial minorities, including "split labor markets" (the empirical reality of white workers generally aligning most closely with white employers rather than nonwhite workers) and "middleman minorities" (Korean American entrepreneurs serving as a buffer between predominantly white businesses in control of production and distribution and poor inner-city African Americans). See, e.g., IVAN Light \& EDNa Bonacich, IMMIGRANT ENTrepreneurs: Koreans IN Los AN. GELES 1965-1982, at 17-20 (1988); George J. Borjas, Immigrants, Minorities, and Labor Market Competition, 40 Indus. \& LAB. ReL. Rev. 382 (1987). Political scientists and ethnic studies scholars also advance power-conflict theories, locating interracial tensions in differing group political and economic power and in the competition for scarce private resources and government entitlements. See Joe R. Feagin \& Clairece Booher Feagin, Theoretical Perspectives in Race and Ethnic Relations, in RACE AND ETHNic Conflict, supra, at 29, 36-45.

158. See supra note 157. 
color on color differs significantly from white on color. ${ }^{159}$ Collectively, what emerges from these two insights specifically, and the socio-political works generally, is this: theoretical and empirical research must expand not only beyond white on black but also beyond white on color to encompass color on color. ${ }^{160}$

For this reason, Angela Harris, through rhetorical questions, suggests expansion, or reorientation, of antidiscrimination law's white on black paradigm.'

Should these groups [particularly Latinos and Asian Americans], more internally diverse than African Americans, nevertheless receive the same legal treatment as African Americans? Should the various subgroups within these "races" be treated identically despite very different material circumstances. ... [T] ties" as a powerful political and cultural force raises the issue of "discrimination" among and between nonwhite groups. To what extent should the law recognize such discrimination, and is it the same as discrimination between whites and nonwhites? ${ }^{161}$

A pending African American employment discrimination suit targeting Asian American managers reveals the complexity of those questions in even "ordinary," minimally publicized, interracial justice settings.

The United Minorities Against Discrimination, an unincorporated community organization, five African Americans, and two Latinos are suing the City and County of San Francisco and the Civil Service Commission. ${ }^{162}$ The plaintiffs assert federal and state civil rights claims of discrimination in the hiring and promotion of African American and Latino personnel analysts. What distinguishes this suit from many other discrimination suits by racial mi-

159. See Almaguer, supra note 6, at 208 (positioning along a racial hierarchy); DAvid Theo Goldberg, Racist Culture 112-13 (1993); Steingerg, supra note 37; Cornel WEST, RACE MATTERS 28-29 (1993); see also supra note 157.

160. Although illuminating, these insights are of limited utility for those entangled in actual interracial controversies. They provide no guidance and little light for racial groups endeavoring to struggle through intergroup competition and conflict and deal with interracial justice claims. These socio-political works operate from a vantage point of outside looking in. They overlay models of social organization onto broad categories of historical, economic, and demographic information. The outside-in structural models tend to attribute all intergroup conflict and the actions of racial groups to large structural forces in society, thereby ignoring, or writing out of existence, the agency of racial groups in the construction of intergroup relations. This denial of agency is troublesome because it rejects the potential for group efforts to rearticulate identities, establish alliances, build coalitions, and participate productively in political affairs. See generally Jo Carrilo, Surface and Depth: Some Methodological Problems with Bringing Native American-Centered Histories to Light, 20 N.Y.U. Rev. L. \& Soc. Change 405 (1993); Steve J. Stern, Feudalism, Capitalism, and the WorldSystem in the Perspective of Latin America and the Caribbean, 93 AM. Hist. REv. 829 (1988).

161. HARRIS, TALK ABout RACE, supra note 117.

162. See Third Amended Complaint, supra note 69, at 105. 
norities is that the apparent discriminators and main beneficiaries of the alleged discrimination are not white; they are Chinese Americans. According to the allegations of the complaint, "Black and Hispanic personnel analysts comprised between 29 and 44 percent of the analyst pool" and, despite requests for promotion by qualified African Americans and Latinos between 1985 and 1990, none was promoted.163 The complaint also alleges that the defendants failed to follow established hiring and promotion procedures and that "certain supervisors" made "disparaging remarks regarding Blacks and Hispanics" with an intent to discriminate. 164

Interestingly, the complaint does not state explicitly that Asian Americans, or Chinese Americans, are the primary beneficiaries of the asserted discrimination. In fact, the complaint is silent as to the races of the beneficiaries of the alleged discrimination, saying only that they are "neither Black nor Hispanic."165 Nevertheless, by listing the names of the "less qualified" applicants who received the positions or promotions, the complaint implicitly racialized its claim. The names identified are predominantly Chinese American - Wong, Wong, Lum, Gee, and (Mei-Long) Sam. ${ }^{166}$ One is Korean American (Ko) and two appear to be white (Heurlin and McAllister). ${ }^{167}$ The complaint also does not list the names or races of the city decisionmakers. Subsequent filings indirectly reveal that key decisionmakers are white (four) and Chinese American (two) and that the person assigned to conduct an internal investigation of plaintiffs' charges is Chinese American. 168

Two salient features of the dispute, which are only hinted at in the complaint, emerged in bits and pieces during discovery and briefing on motions. One feature is the interracial dynamics between the Asian American applicants, supervisors, and the investigator and the African American and Latino applicants. The other feature is the reluctance of the parties and their attorneys to acknowledge, let alone directly address, these dynamics. Neither the plaintiffs' complaint nor the parties' briefs on motions call attention

163. See Third Amended Complaint, supra note 69, at 9.

164. Third Amended Complaint, supra note 69, at 10.

165. See Third Amended Complaint, supra note 69, at 12, 22.

166. See Third Amended Complaint, supra note 69, at 12, 18, 21.

167. See Third Amended Complaint, supra note 69, at 12, 18, 22.

168. See Defendants' Response to Plaintiffs' Statement of Facts at 7, United Minorities Against Discrimination v. City and County of San Francisco, No. C-91-2350 (filed Jan. 27, 1995) (apparent racial breakdown of decisionmakers for one plaintiff who were also involved in other case decisions); Plaintiffs' Supplemental Brief In Opposition to Defendants' Motion for Summary Judgment at 7, United Minorities, No. C-91-2350 (filed May 15, 1995). 
to the color on color interplay. None of the legal filings questions whether antidiscrimination law, originally conceived to handle white-versus-black, majority-versus-minority disputes, needs to be reinterpreted. None of the filings or arguments discusses legal implications of the apparent racial hierarchy: white officials supervising Chinese Americans and white managers accused of discriminating against African Americans and Latinos in favor of Chinese Americans and whites. None of the filings acknowledges other high-profile San Francisco political-legal disputes, discussed earlier, involving Chinese Americans, African Americans, and Latinos.

Indeed, rather than acknowledging the volatile, socially signifcant interracial dynamics of the case, the parties' attorneys agreed to "protect" against public disclosure the "racial designations" of the participants in the hiring and promotion process. ${ }^{169}$ Under threat of contempt, no one can reveal city records on race matters critical to full, context-sensitive understanding of the controversy. Thus, by court-approved stipulation, the parties and attorneys are concealing from public view what for many may be the heart of the case - the African American, Latino, Chinese American, and white intergroup dynamics within a specific social-historical setting.

The apparent racial hierarchy and interminority interplay, only hinted at in the case filings and public documents, complicate plaintiffs' antidiscrimination claims and, in important respects, lift them out of the white-black jurisprudential paradigm. Chinese Americans historically suffered at the hands of whites in San Francisco. In business, housing, and education the Chinese were denigrated and discriminated against by law and social custom for more than one hundred years after their arrival in the mid-1800s.170 Chinese Americans today still face discriminatory treatment. Recent Chinese immigrants tend to fall below the poverty line and to struggle finding adequate housing and jobs, particularly in the wake of California's Proposition 187.171 Young Asian males have been randomly photographed so that mug books can guide Bay Area police

169. See Stipulation and Protective Order at 2, United Minorities, No. C-91-2350 (filed Mar. 29, 1994). The stipulated protective order provides, in relevant part, that certain documents shall "not be exhibited or displayed, and the contents thereof shall not be disclosed." Id. Those documents include "specified documents containing race designations." Id. 139.

170. See Almaguer, supra note 6; Hing, Remaking Asian America, supra note 156, at

171. See Pat Chew, Asian Americans: The 'Reticent' Minority and Their Paradoxes, 36 WM. \& MARY L. Rev. 1, 28-29 (1994); Jim Impoco, California Tries to Give Back the Tired and Poor, U.S. NEwS \& WORLD REP., Nov. 21, 1994, at 42. 
in their search for Asian youth gangs. ${ }^{172}$ In upscale Marin County, an unemployed white male awoke one morning in 1995 and decided to kill an Asian, any Asian. At a nearby store he stabbed in the chest Eddy Wu, the first Asian person he saw. ${ }^{173}$ Many middleclass Chinese Americans perceive continuing discrimination, not only by whites in terms of glass ceilings and sporadic hate violence, but also by African Americans and Latinos through affirmative action. ${ }^{174}$

Despite past and recent history, many Chinese Americans in San Francisco are financially successful, Chinese American political visibility is rising in the Bay Area, and Asian Americans generally exceed their proportionate numbers at University of California campuses. ${ }^{175}$ The newly appointed city chief of police and state Supreme Court justice are Chinese American, as was the recent Chancellor of the University of California at Berkeley. ${ }^{176}$ Indeed, some African Americans perceive Asian Americans as a buffer between whites and blacks, as the "racial bourgeoisie"177 or "middleman minority"178 who, by their partially elevated position in the racial hierarchy, undermine black charges of white supremacy while nevertheless preserving white privilege and slowing black advancement. Some mid-level Asian American managers confirm that charge, at least in part, through their complaint that they are used by white superiors as the "pacifiers" and "shock absorbers."179 They perceive that they are directed to fire or make unrealistic demands of lower-level African Americans and Latinos while absorb-

172. See Cops Promise Action on Asian 'Mug Book,' S.F. Chron., Aug. 2, 1992, at A24.

173. See Torri Minton, Quiet Marin Confronts Hate Crimes: National Study Sees Rise in Violence Against Asians, S.F. Crron., Nov. 29, 1995, at A13.

174. See, e.g., First Amended Complaint, supra note 1, at 9; see also Candy Kit Har Chan, Equitable Admissions, AsIANWEEK, Jan. 26, 1996, at 11 (describing Chinese American belief in the unfaimess of San Francisco public school affirmative action for African Americans).

175. See Don T. Nakanishi, A Quota on Excellence? The Asian American Admissions Debate, in Asian American Educational Experience 273, 280 (Don T. Nakanishi \& Tina Yamano Nishida eds., 1995) (noting that "Asian Americans generally exceed their proportionate numbers" at University of California campuses).

176. See Bill Wong, Sweet and Sour, AstaNweEk, Jan. 26, 1996, at 6 (describing the "cold shower for S.F. euphoria" over the appointment of Chinese American Fred Lau, including the "racially charged contretemps" following his appointment); Alethea Yip, Among the Supremes: Judge Ming Chin Appointed to California Supreme Court, AstaNWEEK, Feb. 1996, at 9.

177. Mari Matsuda, We Will Not Be Used, 1 Asian Am. Pac. Islands L.J. 79 (1993).

178. See supra note 157.

179. Benjamin Pimentel, Asian Americans' Awkward Status: Some Feel Whites Use Them As 'Racial Wedge' With Others, S.F. CHroN., Aug. 22, 1995, at A1. 
ing the flack and insulating their employers from discrimination claims by virtue of their own minority status. 180

Do these complex interracial dynamics undergird the United Minorities' (a seemingly ironic name choice) justice claims? If so, why do those dynamics remain submerged in the litigation substrata? Why are underlying socio-political grievances among Asian Americans, African Americans, and Latinos ignored? And why does no one, litigants, attorneys, or the media, address white racism in the city's institutional bureaucracy? One response to these questions comes in the form of other questions concerning the parties' attorneys. Why have plaintiffs' attorneys, a large, established San Francisco firm, appeared to limit their efforts to a search for evidence of intentional discrimination? "Because that is all the civil rights case law requires" is an apt answer. The focus on "intentional" discrimination, however, misses the important institutionalized aspects of the actual hiring and promotion process. Why have plaintiffs' attorneys cast the case within the narrow, binary whiteblack antidiscrimination law paradigm? "Because that is how antidiscrimination law is framed." The victim-perpetrator, good-bad, either-or framing of the issues, however, belies the multilayered interminority dynamics of this and related justice controversies.

A review of the volumes of court filings in the suit starkly reveals the limits of legal justice and traditional antisubordination practice: The interracial dynamics that appear to be central to illumination and handling of the justice claims are nowhere to be seen or heard. How do differing group histories, changing racial-economic demographics, and shifting group positions in a racial hierarchy both complicate and ground analyses of the United Minorities controversy? We do not know because no one is talking, and no one is talking, it seems, because no one is inquiring. And no one is inquiring, I suggest, because we have not yet developed the foundational concepts and language.

This then raises the larger inquiry: What languages do the law and other disciplines employ to account for, or discount, intergroup dynamics? In the realm of intergroup conflict, the language of community leaders is often assertive, even vociferous. Organizers speak to and about people in their communities in language rooted in both concrete particularities and political strategy. ${ }^{181}$ Journalists speak to a broader audience and often eagerly report on intergroup

180. See id.

181. See Samuel R. Cacas, Minority Lawyers Organize Against California Save Our State Initiative, AsIANwEEK, Sept. 2, 1994, at 1; Ben Q. Limb, New York Launches Black-Korean 
tensions, sometimes with considerable sophistication. ${ }^{182}$ As mentioned, socio-political scholars are interrogating multiple aspects of intergroup conflict.

Compared to recent high-profile community and media commentaries and socio-political studies, courts, lawyers, and legal scholars have spoken little about interracial conflict and justice claims. In the United Minorities discrimination suit, for instance, the judge, lawyers, and parties refuse to talk about - and legal scholars have not weighed in on - what appears to be the heart of the suit's justice claims: an apparent racial hierarchy in one part of city government, with whites at the top and African Americans and Latinos at the bottom, maintained by complicitous Asian Americans in the middle. ${ }^{183}$

Why the comparative silence? Is it in part because justice claims are usually cast within a traditional civil rights white-black, majority-minority, individual perpetrator-individual victim jurisprudential paradigm? The attorneys and parties clearly cast United Minorities within that paradigm. ${ }^{184}$ Is the silence also because color-on-color is rendered inconsequential by the legal irrelevance of color distinctions? Justice Sandra Day O'Connor recently implied as much in Shaw v. Reno, ${ }^{185}$ a case in which the predominantly white North Carolina legislature, at the urging of the U.S. Attorney General and according to the dictates of the Voting Rights Act, altered election district lines to create the state's second black-majority voting district. Writing for the majority, O'Connor observed that all governmental racial classifications should be treated in the same skeptical legal fashion, regardless of whether the classification is designed to end a white-controlled racial caste system or to perpetuate it. ${ }^{186} \mathrm{O}^{\prime}$ Connor implied that races are fungible under the law, that all racial categories should be treated as

Mediation Project, NAPABA LAWYER, Oct. 1994, at 7; New Coalition Formed to Address Racism in Southern California, RAfu SHMPo, June 12, 1992, at 1.

182. See, e.g., Jack Miles, Blacks Versus Browns, ATLANTIC Monrhly, Oct. 1992, at 41; Jeffrey Schmalz, Miami's New Ethnic Conflict: Haitians vs. American Blacks, N.Y. Times, Feb. 19, 1989, at A1; Frank H. Wu, At Lowell High, Who Is Equal to Whom?, S.F. CHRoN., Sept. 21, 1994, at A23.

183. See Third Amended Complaint, supra note 69, at 9.

184. The plaintiffs are employing statutes, Title VII and 28 U.S.C. $\S 1983$, originally designed for black minority victim claims against white majority perpetrators. Plaintiffs' rhetoric ignores interracial interactions and instead somewhat tortuously fits racial references within a binary opposition, referring to defendants' agents as "neither African American nor Hispanic." Third Amended Complaint, supra note 69, passim.

185. 509 U.S. 630 (1993).

186. For a view on the historical, legal, and practical relevance of this distinction, see Adarand Constructors, Inc. v. Pena, 115 S. Ct. 2097, 2120-23 (1995) (Stevens, J., dissenting). 
interchangeable. "Racial classifications of any sort pose the risk of lasting harm to our society," 187 and therefore equal protection analysis "is not dependent on the race of those burdened or benefitted."188 The fact that race is involved is all that matters. Courts need not interrogate racial identities or the history of racial subordination. ${ }^{189}$

O'Connor's approach, which Justice Antonin Scalia endorsed by his ringing pronouncement in Adarand Constructors, Inc. v. Pena, that "we are just one race ... American,"190 presents a twist on the notion of constitutional colorblindness. That twist entails the Court's conscious acknowledgment of interracial competition and conflict in "multiracial America" as justification for its de facto prohibition of affirmative race consciousness in governmental racial classifications. ${ }^{191}$ Implicit in this contradictory recognition-nonrecognition of interracial dynamics is the decision not to develop a meaningful interracial jurisprudence.

How has this occurred? Over the last twenty years, the Supreme Court has used America's multiracial demographics and the existence of interminority competition and conflict to transform whites from the centuries-long historical oppressor of people of color into "just another group competing with many others."192 Based on the Court's rulings, whites now can be considered "a victim group with the same moral and legal claims" as other groups. ${ }^{193}$ A detailed analysis of how this has occurred is beyond the scope of

187. Shaw I, 509 U.S. at 657.

188. 509 U.S. at 651 (quoting City of Richmond v. J.A. Croson Co., 488 U.S. $469,-494$ (1989) (plurality opinion)).

189. See Shaw I, 509 U.S. at 650-51; see also Freeman, supra note 49, at 1412, 1425 (describing "ethnic fungibility" as a core idea of colorblindness).

190. Adarand, 115 S. Ct. 2119 (1995) (Scalia, J., concurring).

191. I use the term "de facto prohibition" because the majority's position is in effect one of colorblindness. While Justices Scalia and Thomas argue for a complete ban on racial classifications, see Adarand, $115 \mathrm{~S}$. Ct. at 2118-19, the majority's formal position is that all racial classifications are subject to strict scrutiny and that a classification will survive such scrutiny under compelling circumstances. See Shaw v. Hunt, 116 S. Ct. 1894, 1899 (1996). The judicial reality, however, has been that strict in theory is fatal in fact. The majority's de facto acceptance of colorblindness as constitutional doctrine is revealed in two ways. The first is Justice O'Connor's stated goal of "eliminat[ing]" governmental use of "racial stereotypes" and her apparent equating of racial stereotypes with the recognition of race. Shaw I, 509 U.S. at 647; see also Bush v. Vera, 116 S. Ct. 1941, 1964 (1996). The second, as Justice Stevens points out in his Shaw II dissent, is that the plaintiffs "claimed [a] violation of a shared [citizens'] right to a colorblind districting process" and that the claim emanates "from the Court's unarticulated recognition of a new substantive due process right to 'colorblind' redistricting itself." Shaw II, 116 S. Ct. at 1909-10 (Stevens, J., dissenting).

192. Natapoff, supra note 26 , at 1062.

193. Id. 
this article. ${ }^{194}$ A summary description, however, is useful. In its most recent rulings, the Court has attributed interminority competition and conflict to "racial factionalism," "separatism," and "balkanization," which in turn it has attributed to consciousness of racial differences. ${ }^{195}$ For the conservative majority on the Court, the evil of racism in intensely conflictual multiracial America is no longer individual and institutional acts of white supremacy, but rather the recognition of racial differences in the form of racial classifications. Race consciousness leads to factionalization and separatism, which lead to conflict. In short, racial classifications "threaten ... to incite racial hostility."196 The very existence of governmental racial classifications, race factions, and interminority conflict are circumstantial proof of the causal links.

With this description of racial reality, the Court's ostensible quest for harmony has focused on outlawing race consciousness. Only by banning consciousness of racial differences can the government avoid fostering race factionalism; only by avoiding race factionalism can the government reduce racial conflict. Of course, a ban on consciousness of racial differences would make sense only if racial distinctions were unworthy of notice - a seemingly tough conclusion to draw in light of America's history of differential white racist treatment of minorities and continuing socio-economic differ-

194. Alexandra Natapoff traces the Supreme Court's treatment of interminority conflicts from United Jewish Organizations of Williamsburgh v. Carey, 430 U.S. 144 (1977), Regents of the University of California v. Bakke, 438 U.S. 265 (1978), City of Richmond v. J.A. Croson Co., 488 U.S. 469 (1989), and Shaw I, 509 U.S. 630, through Johnson v. De Grandy, 114 S. Ct. 2647 (1994), to gain insight into "issues of race-based redistribution, political process, and intergroup conflict that seem to most concem the Court." Natapoff, supra note 26, at 1065 79.

In these recent cases, the Supreme Court denied the existence of racial hierarchies and overlooked complex interminority issues. In UJO, the Court, in employing a "simplistic white/black scheme," id. at 1068, classified Brooklyn's Hasidim as white in order to allow a redistricting plan bisecting the Hasidic community. See UJO, 430 U.S. at 173-74 (Brennan, J., concurring in part). The Court in Bakke advanced the image of minority groups competing for power, characterizing whites as deserving the same protections as historically disadvantaged minorities. See Bakke, 438 U.S. at 317-18. Similarly, in Croson, Justice O'Connor invoked a multiple racial minority context to invalidate Richmond's construction set-aside program, stating that the program's "gross overinclusiveness" of nonblack minority groups rendered the plan disadvantageous to African Americans themselves. See Croson, 488 U.S. at 506. Likewise, the Court in Shaw I recognized the existence of a multiracial polity while warning that "racial gerrymandering may balkanize us into competing racial factions." Shaw I, 509 U.S. at 657. See also supra note 191 and accompanying text. In De Grandy, the Court failed to address the interminority issue by refusing to choose between the creation of either an African American or a Latino district. See De Grandy, 114 S. Ct. at 2663; see also Deborah Ramirez, Multicultural Empowerment: It's Not Just Black and White Anymore, 47 STAN. L. REV. 957, 969-74 (1995) (addressing the limitations of traditional race-based policies and their failure to account for multiracial identity).

195. See Natapoff, supra note 26, at 1062.

196. Shaw I, 509 U.S. at 643. 
ences among whites and nonwhite racial groups. ${ }^{197}$ The Court nevertheless has reached that conclusion by characterizing all racial groups as one and the same: racial groups, including whites, are fungible, with equivalent moral and legal claims to freedom from discrimination. What justifies this characterization? The Court has pointed to the "facts" of multiracial America, where every group inflicts harm upon another. When it comes to discrimination, no group is better or worse than any other: At bottom, "we are just one race."198

Three consequences of this characterization of multiracial conflict are salient. First, as Alexandra Natapoff points out, the Court recognizes multiracial conflicts to justify its ban on affirmative race consciousness. ${ }^{199}$ Second, in practice, the ban on race consciousness is being applied by courts not to promote equality for nonwhite racial groups or to redress interracial justice grievances but to validate white claims of discrimination and to "reliev[e] whites of the costs of forty years of [antidiscrimination] remedial measures."200 Third, and returning to the point of this discussion, the Court's acknowledgment of multiracial conflicts serves ironically as the foundation for its jurisprudential blindness to interracial claims. ${ }^{201}$

These consequences suggest explicit and implicit rationales for the Court's recognition of multiracial conflict without an articulated position on how to analyze or address justice claims arising from those conflicts. Explicitly, an interracial jurisprudence that is attentive to racial differences and intergroup histories is at best unneces-

197. See HACKER, supra note 79 (describing widespread socio-economic inequalities between whites and blacks).

198. The Court's recent rulings in Adarand, Shaw I, Shaw II, and Croson implicitly adopt this line of reasoning. For a critique of the impact of the Court's de facto colorblindness rulings in these cases, see Jayne Chong-Soon Lee, Navigating the Topology of Race, 46 STAN. L. REv. 747 (1994); Morton J. Horwitz, The Supreme Court, 1992 Term - Foreword: The Constitution of Change: Legal Fundamentality Without Fundamentalism, 107 HARV. L. REv. 30, 106-09 (1993); Richard H. Pildes \& Richard G. Niemi, Expressive Harms, "Bizarre Districts," and Voting Rights: Evaluating Election-District Appearances After Shaw v. Reno, 92 Mich. L. REv. 483 (1993); Thomas Ross, The Richmond Narratives, 68 TEXAS L. REv. 381 (1989); Patricia Williams, The Obliging Shell: An Informal Essay on Formal Equal Opportunity, 87 MrCH. L. REv. 2128 (1989); Jen-L-Wong, Casenote: Adarand Constructors, Inc. v. Pena: A Colorblind Remedy Eliminating Racial Preferences, 18 U. Haw. L. Rev. 939 (1996).

199. See Natapoff, supra note 26 , at 1061-62.

200. Id. at 1062 .

201. See Neil Gotanda, A Critique of "Our Constitution is Color-Blind," 44 StAN. L. Rev. $1,5-6,16-28$ (1991) (describing the concept of racial nonrecognition). For an interesting discussion of the "original intent" of the Constitution's framers not to embrace colorblindness, see Jeffrey Rosen, Remarks at Conference, Race, Law and Justice: The Rehnquist Court and the American Dilemma, 45 AM. U. L. REv. 567, 573-75 (1996). 
sary to dispensing racial justice and at worst inimical to the nation's interest in racial harmony. Implicitly, jurisprudential blindness to the dynamics of interracial justice claims enhances the legitimacy of the Court's overall ban on race consciousness.

If this explains, at least in part, the federal judiciary's constricted approach to interracial justice claims, what explains the silence of legal scholars? Why have legal scholars, like the courts, until very recently, refrained from pursuing the jurisprudential underpinnings of intergroup justice claims?202 One possible reason is that the courts' reluctance to acknowledge, let alone engage, the interracial justice issues has deprived scholars of legal records to scrutinize. Another reason for the comparative silence may be that no theoretical core has coalesced. Early efforts at developing an interracial jurisprudence seem fractured and sometimes even at odds. Some authors examine Court treatment of interminority rights issues and search for an intergroup jurisprudential base for adjudicating Title VII and equal protection antidiscrimination claims. ${ }^{203}$ Others focus on the process of adjudicating antidiscrimination claims and the potential for lawyer exacerbation of intergroup conflicts;204 on intergroup reconciliation predicated on "doing justice"; 205 and on monopoly capitalism and the fostering of interminority economic competition. ${ }^{206}$ With these articles in the foreground, the foreword to the Stanford Law Review symposium, by Charles Lawrence III, tacks in the opposite direction. It cautions race scholars about the

202. In 1989, Mari Matsuda suggested that race jurisprudence attend to differences in racial and ethnic groups in terms of power and political participation. See Mari J. Matsuda, Public Response to Racist Speech: Considering the Victim's Story, $87 \mathrm{MrcH}$. L. REv. 2320, 2324 (1989). Of the recent articles addressing the topic, several were published in 1993 following the South Central Los Angeles uprising and the remainder in 1995. See Brest \& Oshige, supra note 81; Cho, supra note 24; Dong, supra note 26; Bill Ong Hing, Beyond the Rhetoric of Assimilation and Cultural Pluralism: Addressing the Tension of Separatism and Conflict in an Immigration-Driven Multiracial Society, 81 CAL. L. REv. 863 (1993); Bill Ong Hing, In the Interest of Racial Harmony: Revisiting the Lawyer's Duty to Work for the Common Good, 47 Stan. L. Rev. 901 (1995) [hereinafter Hing, Racial Harmony]; Lisa C. Ikemoto, Traces of the Master Narrative in the Story of African American/Korean American Conflict: How We Constructed "Los Angeles," 66 S. CAL. L. Rev. 1581 (1993); Charles R. Lawrence III, Foreword: Race, Multiculturalism, and the Jurisprudence of Transformation, 47 STAN. L. REV. 819 (1995) [hereinafter Lawrence, Transformation]; Natapoff, supra note 26; Deborah Ramirez, supra note 194; Reginald Leamon Robinson, "The Other Against Itself": Deconstructing the Violent Discourse Between Korean and African Americans, 67 S. CAL. L. REv. 15 (1993); Yamamoto, Rethinking Alliances, supra note 149; see also Kimberle Crenshaw, Mapping the Margins: Intersectionality, Identity Politics, and Violence Against Women of Color, 43 STAN. L. Rev. 1241 (1991) (analyzing identities within racial communities).

203. See Natapoff, supra note 26; Ramirez, supra note 194.

204. See Hing, Racial Harmony, supra note 202.

205. See Yamamoto, Rethinking Alliances, supra note 149.

206. See Robinson, supra note 202. 
distracting potential of interracial inquiry: the diversion of attention from the structural source of intergroup conflict in America white supremacy.207 Perhaps this all-over-the-map feel to the few articles on interracial jurisprudence simply means that interminority jurisprudence is in its early stages; perhaps it indicates scholarly ambivalence.

Still another explanation for the lack of attention to interracial justice issues, which applies to the courts and litigants as well as legal scholars, may be political. Discussion of interracial group conflict is considered taboo, a subject too explosive for whites who want not to be perceived as saying simply "see, they're racist too," and for people of color who do not want to detract societal and legal focus from white positioning atop a racial hierarchy.

For these reasons, among others, it is unsurprising that workable legal frameworks and language for interracial justice have yet to emerge. This void, although understandable, is a highly problematic aspect of law's intensifying dissociation from racial justice. Workable frameworks and language are necessary not only to challenge the Court's jurisprudential blindness, not only to address justice claims arising from the realities of interminority conflicts, but also, I assert, to facilitate the formation of durable interracial alliances and coalitions.

Prominent race scholars Manning Marable and bell hooks, speaking to teachers, political lawyers, and community activists, locate the only hope for African Americans and other racial minorities in the formation of interracial alliances, whether those alliances are created to enhance cooperative working and living arrangements or to combat white racism. ${ }^{208}$ Marable's "theory of liberation," which is built on a "transformationist redistribution of resources and the democratization of state power along more egalitarian lines," and hook's "practical model for social change," which speaks to the inducement of enlightened whites to surrender race privileges, both depend upon political power mustered through coalitions of racial groups that are, at some deep level, mutually distrustful. The problem with this vision, as George Fredrickson points out, is that neither Marable nor hooks offers a persuasive view of how to forge interracial alliances or form and maintain co-

207. See Lawrence, Transformation, supra note 202.

208. See bell hooks, Killing Rage: Ending Racism 201-03 (1995); Manning Marable, Beyond Black and White: Transforming African-American Politics 194-202 (1995). 
alitions at a time of "disruptive equilibrium."209 I suggest that theorizing about and acting practically upon concrete interracial justice claims is one aspect of the "how to." In the face of increasingly complex intergroup justice grievances and the limits of legal justice, the call for alliances and coalition-building underscores the need for development of a sophisticated interracial jurisprudence with practical implications. That jurisprudence needs to unravel the ideological strands of the Court's recognition of multiracial conflict to justify its ban of affirmative race consciousness, to interrogate the complexities of group agency and responsibility for disabling intergroup constraints, and in doing so to respond to justice grievances among communities of color that undermine alliance-forging efforts. ${ }^{210}$

\section{Rethinking Race Theory and Political Lawyering Practice: The Practical Turn in Reconstructive JURISPRUDENCE}

In addressing limits of antisubordination practice, Part I described a disjuncture between progressive race theory on the one hand and political lawyering practice and community activism on the other. Part II described the dissociation of antidiscrimination law from racial justice for racial communities and identified five broad socio-legal explanations. That Part also explored the inadequacy of the white-on-black jurisprudential paradigm for interracial justice claims. The disjuncture and dissociation, I suggest, cloud racial minorities' perceptions of justice in post-civil rights America: they recognize the United States' history of racial injustice through law while questioning contemporary antidiscrimination law's capacity for engendering justice; and they see continuing white dominance in many facets of American life while acknowledging changing racial demographics, increasing interracial conflict, and the legal system's reluctance to engage meaningfully with the dynamics of those conflicts. In this setting, progressive race theorists, political lawyers, and racial communities struggle against potent neoconservative race practice.

As part of this struggle, I suggest an emphasis on a reconceived theoretics of practice - a critical race praxis. Critical race praxis seeks to bridge at least partially both the "gap of chasmic propor-

209. See Fredrickson, supra note 143 , at 16-18.

210. See infra section IV.B.3 (outlining an interracial praxis); see also Yamamoto, $R e$ thinking Alliances, supra note 149, at 60 (developing the notion of differential racialization and constrained racial group agency as part of a framework for interracial justice). 
tions" between race theory and political lawyering and the growing divide of law from racial justice. It focuses neither on abstract race theory nor on narrow legal doctrine, although these are aspects of bridging. As described in the Part IV, critical race praxis focuses on developing and then translating critical theoretical insights about race, culture, and law into operational ideas and language for antisubordination practice and, in turn, rethinking theory in light of new practice experience.

In this Part, I critique and extend insights of critical theory and pragmatism to locate critical race praxis within a jurisprudence of reconstruction. That jurisprudence of reconstruction, including its "practical turn," inhabits the tension between postmodernism's despairing unpacking of liberal legalism and modernism's zealous embrace of liberatory ideals of equality and justice. I acknowledge, without engaging in, the sometimes intense debates about the conceptual soundness, political legitimacy, and practical viability of divergent theoretical schools. ${ }^{211}$. The purpose of the following sections is not to fully describe or compare and evaluate theoretical schools, but to employ and extend available insights to recognize a jurisprudence of reconstruction and, within it, to sketch a framework for a race praxis.

\section{A. Critical Race Theory: Inhabiting the Tension}

Critical race theory both illuminates and offers a beginning response to the limitations of legal justice for racial minorities. It does so by employing critical pragmatic tools to examine racial justice in connection with the interplay of law, race, culture, and social structure. ${ }^{212}$ A summary of the "distinctive insights" of critical race

211. See, e.g., Anne Coughlin, Regulating the Self: Autobiographical Performances in Outsider Scholarship, 81 VA. L. REv. 1229 (1995) (charging critical race theorists and feminist legal scholars with replicating existing liberal social arrangements through their misuse of autobiography); Jerome Culp, Telling a Black Legal Story: Privilege, Authenticity, "Blunders," and Transformation in Outsider Narratives, 82 VA. L. REv. 69 (1996) (response to Coughlin critique); Richard Delgado, Coughlin's Complaint: How to Disparage Outsider Writing, One Year Later, 82 VA. L. Rev. 95 (1996) (response to Coughlin critique).

212. Concerning racial justice, critical theory's challenge to modemism produces four inquiries into understandings about socio-legal institutions, processes, and relationships. The "critical" dimension of the inquiry demands critical social analysis: (1) recognition that existing social identities and arrangements are not necessarily rational, natural, or inevitable, thus offering possibilities for social action for subordinated groups; (2) an account of the historical and cultural conditions that shape the point of view of social actors, thus acknowledging that actors may be differently situated and have differing vantage points from which they view the social world; (3) an examination of power and societal structures (political, economic, religious, social), thereby illuminating connections between power and the construction of knowledge and between the use of knowledge and oppression or liberation; and (4) scrutiny of social meanings attached to dynamic categories (such as race, African Americanism, equality) and frameworks (such as legal liberalism, neoconservatism, Marxism), 
theory ${ }^{213}$ is useful, even though it overlooks nuance and internal disagreement and purveys what may be an overstated sense of political unity among critical race scholars.

Critical race theorists seek to eliminate, or at least diminish, racial oppression in American society. ${ }^{214}$ To achieve this they endeavor to transform jurisprudential dialogue in a way that furthers antisubordination practice. The "critical" aspect of their project draws upon postmodern theory. ${ }^{215}$ Critical race theorists deconstruct the limitations of traditional liberal legal discourse and the ways in which that discourse tends to exclude voices on society's margins and to perpetuate structural inequality.216 They thus reveal the social construction of legal concepts presented as fixed and natural, challenge the "efficacy of both liberal legal theory and communitarian ideals as vehicles for racial progress, destabilize the supposedly neutral criteria of meritocracy and social order, and call for a re-examination of the very concept of 'race.' "217

In this fashion, critical race theorists draw upon postmodern analytical techniques to reveal the law's blindness toward unconscious racism, ${ }^{218}$ the ways in which legal discourse inscribes and reproduces subordinating images of racial groups, and the ways in which legal institutions and discourse contribute to the construction and maintenance of racial hierarchies. ${ }^{219}$ In short, critical race theory analyzes ways in which law ignores cultural domination within law's own processes and the ways in which those processes contribute to racial oppression.

The illuminating embrace of deconstruction, however, poses a postmodernist dilemma for critical race theorists committed to jus-

thereby recognizing ways context imbues categories and frameworks with social significance and linking individuals and groups to social structures. See generally CRAIG CALHOUN, CruTICAL SOCIAL THEORY 35-36 (1995) (explaining four forms of critical social theory that depend on historical understanding and analysis).

213. See Robert L. Hayman, Jr., The Color of Tradition: Critical Race Theory and Postmodern Constitutional Traditionalism, 30 HARv. C.R.-C.L. L. REv. 57, $62-64$ (1995).

214. See Mari J. Matsuda et al, Words That Wound: Critical Race Theory, Assaultive SpeEch aNd tHE FIRST AMENDMENT 6-7 (1993).

215. My use of the term "critical theory" conflates several schools of postmodern thought, including poststructuralism, deconstruction, and critical social theory. See Harris, Jurisprudence of Reconstruction, supra note 35, at 749-50.

216. See Cook, supra note 114 , at $989-92$ (defining deconstruction).

217. Hayman, supra note 213, at 62-63 (footnotes omitted). See generally Critical

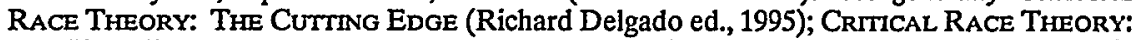
The Key Writings That Formed the Movement (Kimberlé Crenshaw et al. eds., 1995).

218. See Lawrence, Unconscious Racism, supra note 117, at 342-44.

219. See supra notes $95-105$ and accompanying text. See also Freeman, supra note 49 , at 1409. 
tice through law. Postmodernity's "crisis of truth is concomitant with a crisis of justice." 220 Because postmodern theory undermines both the positive and normative aspects of law, it deprives legal justice of its conventional foundation.

[Postmodernism] suggest[s] that what has been presented in our social-political and our intellectual traditions, as knowledge, truth, objectivity, and reasons are actually merely the effects of a particular form of social power, the victory of a particular way of representing the world. 221

Fully extended, it means that law "cannot be authentic, cannot be determinate, cannot be justified." 222 In short, justice cannot exist through law. Civil rights laws, and the civil rights movement that gave rise to those laws, engender little more than illusions of racial progress while reinforcing harmful racial hierarchies. Some critical theorists accept this extended postmodern "truth."223

Others, including many critical race theorists, feminist legal scholars, pragmatists, and gay and lesbian scholars, at least partially reject it. They understand the limits of "rights talk" and the ways in which civil rights laws can be used to reinforce the racial status quo. They also, however, perceive potentially transformative value in law and rights assertion for disempowered groups, and they embrace modernist notions of hope and justice through reconceived ideas of law and political struggle.224 They seek to shape "affirmative projects ... [i]nformed not only by theory but also by the lived experience ... dedicated not merely to deconstructive critique but as well to a reconstructive praxis." 225

Critical race theorists thus face an apparent "performative contradiction" - employing theoretical tools that deny law's authenticity while seeking to remake law practically so that it performs for the end of racial justice. Angela Harris locates within that tension potential for a reconstructive jurisprudence that uses upgraded modernist tools to attack the material conditions of racial oppression without acceding to illusions of voluntary power sharing or an

220. Hayman, supra note 213 , at 61 .

221. Anthony E. Cook, Reflections on Postmodernism, 26 New ENG. L. REv. 751, 757-58 (1992).

222. Hayman, supra note 213 , at 61.

223. See, e.g., Peter Gabel, The Phenomenology of Rights - Consciousness and the Pact of the Withdrawn Selves, 62 TExas L. REv. 1563 (1984).

224. See Elvia R. Arriola, Gendered Inequality: Lesbians, Gays, and Feminist Legal Theory, 9 BeRKeley Women's L. J. 103 (1994); Patricia J. Williams, Alchemical Notes: Reconstructing Ideals From Deconstructed Rights, 22 HaRv. C.R.-C.L. L. REv. 401 (1987).

225. Hayman, supra note 213 , at 61 . 
inevitable societal march toward racial justice. 226 More particularly, Harris argues that the task should not be to try to resolve the tension abstractly, "but rather consciously to inhabit that very tension" - to "attempt to reconstruct political modernism itself" by drawing upon that which has made it indispensable to people of color in their struggles against racial subordination and by restructuring that which has made it inadequate. ${ }^{227}$ She perceives critical race theory's ultimate vision as redemptive and offers an approach to remaking modernism that is both sophisticated and disenchanted in its efforts to link race theory with antisubordination practice. ${ }^{228}$

\section{B. Jurisprudence of Reconstruction: The Practical Turn}

The jurisprudence of reconstruction lays a conceptual foundation for the continuing struggle against racial oppression. Two clusters of critical race scholarship, explicitly embracing a critical pragmatic approach to law, build upon that foundation and introduce a practical reconstructive dimension to race writing. One cluster of critical race writing endeavors to integrate high theory with antisubordination legal doctrine. Mari Matsuda, Charles Lawrence III, Richard Delgado, and Kimberle Crenshaw, for example, in their book Words that Wound, reconstruct constitutional and tort doctrines to address regulation of public and private racial hate speech. In other works, Matsuda offers a reinterpretation of Title VII doctrine for accent discrimination, ${ }^{229}$ and Lawrence draws upon Freudian and cognitive psychology in deriving a "cultural meaning" test to evaluate equal protection race discrimination challenges.230 In related fashion, Jerome Culp explores the Supreme

226. See Harris, Jurisprudence of Reconstruction, supra note 35, at 743-44 (crediting Mari Matsuda with articulation of the reconstructive jurisprudence concept and developing it further).

227. See id. at 760 .

228. See id. at 766-67. In order to develop a sophisticated theory of the racialized subject, Harris suggests that critical race theory continue to draw upon scholarship from other disciplines and look beyond the black-white struggle. She proposes that critical race theory aspire to disenchantment with reason by "giving up a certain romanticism about the rhetorical apparatus of modemism" while focusing on the "moment to moment struggles to alleviate suffering and alienation." Id. at 778. By recognizing the limitations of rationalism in antiracist struggle, she suggests that critical race theorists focus on empowerment as a goal in itself instead of as a step on the road to emancipation. See also Frank Michelman, Bringing Law to Life: A Plea for Disenchantment, 74 CoRnell L. Rev. 256, 257, 268 (1989) (describing a dialogic conception of politics and arguing for "bringing law back to politics and politics back to the law"); Mari J. Matsuda, When the First Quail Calls: Multiple Consciousness as Jurisprudential Method, 11 WoMEN's RTS. L. REP. 7 (1989) [hereinafter Matsuda, Multiple Consciousness] (calling for multiple consciousness as part of a jurisprudence of reconstruction).

229. See Mari J. Matsuda, Voices of America: Accent, Antidiscrimination Law, and a Jurisprudence for the Last Reconstruction, 100 YALE L.J. 1329 (1991).

230. See Lawrence, Unconscious Racism, supra note 117. 
Court's recent Title VII cases and offers a reform proposal for antidiscrimination policy as part of a larger strategy for change. ${ }^{231}$ Lisa Ikemoto reconstructs forced medical treatment-pregnancy analysis $^{232}$ and Taunya Banks examines discrimination against women of color with AIDS $^{233}$ in light of critical theory insights. Roy Brooks and Mary Jo Newborn, in their critique of critical race theory, conclude on balance that critical race theory offers transformative approaches to traditional equal protection and Title VII doctrines. ${ }^{234}$

A second cluster of critical race theory writing links critical race theory insights about multiple consciousness ${ }^{235}$ and alternative and transformative ways of legal "knowing" to processes of racial justice. Gerald Torres links those insights to the practical import of "local knowledge,"236 and Robert Williams, Jr. connects them to methods underlying a North American indigenous vision of "how different peoples from radically divergent cultural backgrounds try to achieve peace and accommodation." 237 In another work I tie those and related insights specifically to court process - a view of courts as sites of, and participants in, "cultural performances" concerning outsider challenges to existing social and legal arrangements. ${ }^{238}$ That view of court process draws upon the work of Delgado and Lawrence, among others, which constructs sophisticated frameworks for the understanding and employment of narratives in law. 239

231. See Jerome McCristal Culp, Jr., Small Numbers, Big Problems, Black Men, and the Supreme Court: A Reform Program for Title VII After Hicks, 23 CAP. U. L. Rev. 241 (1994); see also Crenshaw, supra note 37; Jerome McCristal Culp, Jr., The Michael Jackson Pill: Equality, Race, and Culture, 92 Mich. L. Rev. 2613 (1994); D. Marvin Jones, No Time for Trumpets: Title VII, Equality, and Fin de Siècle, 92 MrCH. L. Rev. 2311 (1992).

232. See Lisa Ikemoto, Furthering the Inquiry: Race, Class, and Culture in the Forced Medical Treatment of Pregnant Women, 59 TENN. L. REv. 487 (1992).

233. See Taunya Lovell Banks, Women and AIDS - Racism, Sexism and Classism, 17 N.Y.U. Rev. of L. \& Soc. Change 351 (1989-1990).

234. See Roy L. Brooks \& Mary Jo Newborn, Critical Race Theory and Classical-Liberal Civil Rights Scholarship: A Distinction Without a Difference?, 82 CAL. L. REv. 787 (1994).

235. See Angela P. Harris, Race and Essentialism In Feminist Legal Theory, 42 StaN. L. Rev. 581 (1990); Matsuda, Multiple Consciousness, supra note 228.

236. See Gerald Torres, Local Knowledge, Local Color: Critical Legal Studies and the Law of Race Relations, 25 SAN DIEGo L. ReV. 1043 (1988).

237. Robert A. Williams, Jr., Linking Arms Together: Multicultural Constitutionalism in a North American Indigenous Vision of Law and Peace, 82 CAL. L. REv. 981, 994 (1994).

238. See Eric K. Yamamoto et al., Courts and the Cultural Performance: Native Hawaiians' Uncertain Federal and State Law Rights to Sue, 16 U. Haw. L. REv. 1 (1994) [hereinafter Yamamoto et al., Cultural Performance].

239. See Richard Delgado, Storytelling for Oppositionists and Others: A Plea for Narrative, 87 Mich. L. REv. 2411 (1989) [hereinafter Delgado, Storytelling for Oppositionists]; 
Those clusters of reconstructive writing, taken together, can be described as the critical race theory practical turn. That practical turn responds in part to the caution over "hyperabstract theorizing [among scholars] that makes a public debate about race and racism impossible," 240 and in part to the critical race theory goal of contributing materially to diminishing racial oppression. It responds not only to the limitations of legal justice but also to the disjuncture between progressive race theory and political lawyering and the limits of antisubordination practice.

That practical turn itself, thus far, appears to be both salutary and limited. On the one hand, it addresses antisubordination practice in a potentially useful fashion. It addresses judicial acceptance and application of new, possibly racially transformative, legal rules and methods. Judges comprise the primary audience for those writings-particularly federal judges. Civil rights and political lawyers comprise the secondary audience - those, in traditional terms, actually "doing law" for people; those arguing the rules and working with methods of factual proof on behalf of individual or organizational disputants involved in litigation.

On the other hand, critical race theory's practical turn, as reflected in these clusters of writing, is limited. It focuses potentially transformative antisubordination practice on judges, lawyers, legal analysis, and methods of proof. Judges and lawyers are often crucial players in race controversies, and new doctrines and procedural rules, if adopted and applied, can assist antisubordination claimants. Critical race theory's own analyses of doctrine and process, however, sharply reveal law's contingency and indeterminacy in handling race controversies, usually to the detriment of racial group members, particularly in an era of conservative Reagan- and Bushappointed judges. ${ }^{241}$ The focus of critical race theory's practical turn on legal analysis and the reframing of legal doctrine is thus useful yet limited.

In light of critical race theory's recognition of the special value of "rights talk" for racial communities, ${ }^{242}$ I assert something more is at play. That something more moves rights discourse beyond what judges and lawyers are traditionally thought to do in the courtroom and through case opinions. That something more is found in the

Charles R. Lawrence III, If He Hollers Let Him Go: Regulating Racist Speech on Campus, 1990 DuKe LaJ. 431 (1991).

240. Harris, Jurisprudence of Reconstruction, supra note 35, at 779.

241. See Derrick Bell, And We Are Not Saved 5 (1987).

242. See Patricia J. Williams, The Alchemy of Race AND Riofis 146-65 (1991). 
practical, real-world benefits and disadvantages of modernist narratives for communities of color that are struggling politically, economically, and legally against subordination. ${ }^{243}$ These narratives tend to embrace into the language of rights, which derive meaning not from their objective truth, but from how they facilitate self-definition by those often ignored and from how they galvanize and support multifaceted racial group actions against subordination in places and at levels at which subordination is experienced and contested - in courtrooms, schools, workplaces, churches, government agencies, public accommodations, and social clubs. That something more is praxis.

\section{Critical Race Praxis}

At a gathering of law teachers of color in March of 1995, Robert Williams, Jr. called for a future critical race practice. Wondering how professors unconnected with actual antiracist struggles could produce meaningful progressive theory, he urged race scholars to spend less time on abstract theorizing and more time on actual community law-based antisubordination practice. ${ }^{244} \mathrm{He}$ encouraged scholars' involvement in setting up legal clinics, working with community organizations, guiding student activists, advising local tribunals, speaking with politicians and bureaucrats, and drafting regulations.

Similarly, in Rebellious Lawyering ${ }^{245}$ Gerald López argues for antisubordination theorizing that focuses on practical communitycentered lawyering. He offers a foundation for progressive lawyering grounded in the particulars of peoples' lives, supportive of community members' problem-solving skills, and sensitive to the dynamics of neighborhood, local, state, and national politics. In related fashion, Luke Cole calls for environmental justice for poor people and people of color. He suggests "practicing law in a way that empowers people, that encourages the formation and strengthening of client groups, and that sees legal tactics in the context of broader [political] strategies."246

243. See Harris, Jurisprudence of Reconstruction, supra note 35, at 753. Those narratives embrace a "faith ... that enlightenment leads to empowerment, and that empowerment leads to emancipation." Id. at 753.

244. See Robert Williams, Jr., Keynote Address at Western Law Teachers of Color Conference (Mar., 1995).

245. LOPEZ, supra note 44.

246. Luke Cole, Empowerment as the Key to Environmental Protection: The Need for Environmental Poverty Law, 19 EcoloGY L.Q. 619, 648, 654 (1992). 
Williams thus calls for critically informed race practice, López for community-centered rebellious lawyering, and Cole for legal tactics by racial minorities and the poor cast within the context of broader political strategies. I move a step further in the jurisprudence of reconstruction. I suggest for progressive race scholars, political lawyers, and community activists an explicit race praxis characterized by reflective action: infusing antiracism practice with aspects of critical inquiry ${ }^{247}$ and pragmatism, ${ }^{248}$ and then recasting theory in light of practical experience. Race praxis begins to address directly the disjuncture between progressive race theory and political lawyering practice and to respond in part to the dissociation of law from racial justice. For race theorists, a race praxis may mean enhanced attention to theory translation and deeper engagement with frontline action; for political lawyers and community activists, it may mean increased attention to a critical rethinking of what race is, how civil rights are conceived, and why law sometimes operates discursively as a power strategy. For theorists, lawyers, and activists collectively, it may encompass a critical reframing of

247. See supra note 212 ; see also Cook, supra note 114, at 1012-14 (urging a critical praxis grounded in Martin Luther King's linkage of "critical theology" with strategies of political mobilization).

248. In the late $1980 \mathrm{~s}$, the pragmatism of the early 20 th century reemerged in philosophy and law. See Richard RorTy, CoNTINGENCY, IroNY, AND SOLIDARITY (1989); CORNEL West, The American Evasion of Philosophy (1989); Cornel West, Prophetic FraG. MENTS (1988); Martha Minow \& Elizabeth V. Spelman, In Context, 63 S. CAL. L. Rev. 1597 (1990); Margaret Jane Radin, The Pragmatist and the Feminist, 63 S. CAL. L. Rev. 1699 (1990); Joseph Singer, Property and Coercion in Federal Indian Law: The Conflict Between Critical and Complacent Pragmatism, 63 S. CAL. L. Rev. 1821 (1990). For some legal pragmatists, practical reasoning offered a rough but workable alternative to the widely challenged positivist legal method, or legal formalism. See, e.g., Richard A. Posner, Legislation and Its Interpretation: A Primer, 68 NEB. L. Rev. 431 (1989); Richard A. Posner, What Has Pragmatism to Offer Law?, 63 S. CaL. L. REv. 1653 (1990). For others, the more extreme practical-reasoning proponents suffered from the same infirmity as their predecessors: they offered no normative baselines for decisionmaking and their resort to "common sense" simply shielded bald personal preferences and intuitive judgments. See Steven Walt, Some Problems of Pragmatic Jurisprudence, 70 TeXas L. Rev. 317, 330-31 (1992) (reviewing RichARd A. Posner, The Problems of JuRisprudence (1990)). In response to these concerns about revived pragmatism's "impoverished pluralism," while acknowledging its continuing methodological appeal, Mari Matsuda in 1990 called for a "pragmatism modified." Mari J. Matsuda, Pragmatism Modified and the False Consciousness Problem, 63 S. CAL. L. Rev. 1763 (1990) [hereinafter Matsuda, Pragmatism]; see also Radin, supra. Consistent with traditional pragmatism and more recent approaches to practical reasoning, Matsuda identified a critical pragmatic method that "suggests plural, provisional, and emergent truths ... [and] is skeptical of universalized experience and absolute description[s]," and that emphasizes multiple consciousness, experience, flexibility, and context. Matsuda, supra, at 1768. In addition, modified pragmatism embraces "rectification of past injustice and elimination of all present forms of subordination" as first principles. Id. See also GolDBERG, supra note 159, at 215 ("Pragmatists are thus committed, both philosophically and practically, to oppose all forms of oppression and domination and to avoid, resist and reject all hierarchical orders in modes of thinking and social formations."). This latter suggestion bends traditional pragmatism "toward liberation." See id. at 216. 
and engagement with racialized practices in business, bankruptcy, labor, landlord-tenant, family, immigration, and international law as well as evidence, advocacy, and procedure.

\section{A. A Definition}

Critical race praxis, as I conceive it, combines critical pragmatic socio-legal analysis with political lawyering and community organizing for justice practice by and for racialized communities. ${ }^{249}$ Its central idea is racial justice as antisubordination practice. As recognized in the pathbreaking empirical studies of Lind and Tyler, in addition to ideas and ideals, justice is something experienced. ${ }^{250}$ Grounded in concrete, often messy and conflictual racial realities, it is something with which people struggle viscerally and intellectually. ${ }^{251}$

249. Praxis, as I use the term, is antisubordination action with refiection. See Paulo Freire, PedAGOGY OF THE OPPREsSed 52 (1974). Freire, a Brazilian educator, worked with poor, rural farmers against an oppressive government and private landholding system. He connected the role of theorists to grassroots work and popular political movements. Freire's teachers-intellectuals developed liberation theory from the experiences of the poor and, through pastoral workers and community leaders, translated theory into frontline engagement with antisubordination practice. Focusing on reading and writing as tools of organization and action, Freire's praxis of experience-rethinking-translation-engagement produced for the farmers and their collaborators opportunities for reflective action. See id. at 52 .

From the same soil that nourished Freire's praxis, liberation theology emerged in the 1970 s in response to Latin American governments' oppression of the poor. See generally Phillip BerRyman, Liberation Theology: Essential Facts About the ReVolution MOVEMENT IN LATIN AMERICA AND BEYOND (1987). Radical theologians reinterpreted Christian faith from the perspective of the poor, used theology to criticize oppressive social structures and ideologies, and critiqued church orthodoxy. See id. at 4-7. In translating critique into practice, the theologians deepened Freire's notion of praxis. They identified a theory-of-praxis, meaning theory about oppression and resistance continually reformulated by the insights, questions, and experiences of those oppressed. They also identified a theoryfor-praxis, meaning theoretical "input [in]to grass-roots action in the form of criteria, methods," and theory guiding antisubordination community practices. Id. at 86.

250. See LIND \& TYLER, supra note 106. Praxis scholars, according to Charles Lawrence, are "practitioners of the word" - those who integrate teaching, scholarship, learning, and activism. See Charles Lawrence III, The Word and the River: Pedagogy As Scholarship As Struggle, 65 S. CAL. L. REv. 2231 (1992). Consistent with the idea of practitioners of the word, Lawrence and Mari Matsuda have a forthcoming work on affirmative action that, in important respects, is a praxis work. Blending theory, empirical studies, stories, personal narratives, and activist experience, and linking history to current conditions, their book endeavors to translate critical socio-legal analyses into compelling insights about, and practical arguments for, affirmative action that are addressed to theorists, civil rights lawyers, and activists. See Mari J. Matsuda \& Charles Lawrence III, We Won't Go Back: Making THE CASE For AfFirmative Action (forthcoming 1997).

251. See infra section IV.B.1 (grounding race praxis in racial realities). For an account of race praxis by political lawyers and activists concerning the literal enslavement of immigrant Thai garment workers in Los Angeles, see Julie Su, The In/visibility of Asian Garment Workers in Our Economic and Legal Systems: The Garment Industry's Dirty Laundry, J. Gender, RACE, \& JusT. (forthcoming 1997) (describing critical socio-legal analyses about race-gender issues, political organizing and activism, federal court litigation, and coalition-building with Latina sweatshop workers). 
Critical race praxis provides structure to justice practice. It means understanding justice in terms of both method (experiencerethinking-translation-engagement) and norm (first principles of antisubordination and rectification of injustice).252 Race praxis thus directs theorists, lawyers, and activists to the specifics of the immediate grievance or claim (for example, the race-infused interaction between merchant and customer, the promotion-denial Title VII claim in United Minorities) and at the same time pushes them to probe further. It instructs them to employ theory to interrogate subtext to identify the disabling cultural representations and exercises of group power underlying or exacerbating the specific grievance, and to assess critically the institutional dynamics (limitations and potential) of the setting in which justice is practiced. It also encourages them to translate the insights gleaned from critical socio-legal inquiry into operational ideas and language for individuals and groups working to redress grievances. It also means, in appropriate instances, critiquing and moving beyond notions of legal justice pragmatically to heal disabling intergroup wounds and forge intergroup alliances.

What I offer here are the beginnings of a framework rather than a fully developed critical race praxis. As part of that framework, and drawing selectively upon insights of critical race theory, pragmatism, prophetic theology, ${ }^{253}$ feminist legal theory, ${ }^{254}$ and envi-

252. Methodologically, as part of the critical pragmatic process of experience-rethinkingtranslation, see supra note 249 , race praxis recognizes multiple consciousness, experience, and flexibility as tools of inquiry, critical pragmatism "give[s] special credence to the perspective of the subordinated." Matsuda, Pragmatism, supra note 248, at 1764. It identifies experiences and narratives of those traditionally on society's margins - not because those experiences and narratives are "more true" or "more worthy," but because in mainstream justice discourse they tend to be ignored or minimized. Normatively, race praxis commits its method to reconstruction, to the "rectification of past injustice and the elimination of all present forms of subordination." Id. at 1768 . It measures a legal strategy by a pragmatic question: "Does the strategy help dismantle structures of subordination?" Id. at 1771 .

For an account of race praxis by political lawyers and activists conceming the literal enslavement of immigrant Thai garment workers in Los Angeles, see Su, supra note 251 (describing critical socio-legal analyses about race-gender issues, political organizing and activism, federal court litigation, and coalition-building with Latina sweatshop workers).

253. See supra notes $212-44$ and accompanying text (discussing critical race theory, pragmatism, and prophetic theology).

254. Integrating aspects of critical pragmatism, feminist legal theory has developed a rich, practice-tested notion of praxis. Feminist legal praxis integrates theoretical insights about knowledge, Ianguage, and power into antisubordination legal practice. See Carol Sanger, Feminism and Disciplinarity: The Curl of the Petals, 27 Lox. L.A. L. Rev. 225 (1993); Elizabeth Schneider et al., Feminist Jurisprudence - The 1990 Myra Bradwell Day Panel, 1 COLUM. J. Gender \& L. 5 (1991). Feminist legal scholars thus have exposed the nonneutral legal meanings of family, work, equality, abuse, and welfare and how through those meanings the law reinforces certain societal perspectives, devalues others, and helps shape community understandings of events and relationships. See Lucinda M. Finley, Breaking Women's Silence in Law: The Dilemma of the Gendered Nature of Legal Reasoning, 64 NOTRE DAME L. 


\section{ronmental justice scholarship,255 I suggest four starting points of race praxis inquiry. These starting points are the conceptual, the}

Rev. 886, 888 (1989); Amy E. Hirsch, Income Deeming in the AFDC Program: Using Dual Track Family Law to Make Poor Women Poorer, 16 N.Y.U. Rev. L. \& Soc. Change 713, 733-36 (1987); Deborah Maranville, Feminist Theory and Legal Practice: A Case Study on Unemployment Compensation Benefits and the Male Norm, 43 Hastings L.J. 1081 (1992); Deborah L. Rhode \& Martha Minow, Reforming the Questions, Questioning the Reforms: Feminist Perspectives on Divorce Law, in DivorCe ReFORM AT THE Crossroads 191 (Stephen D. Sugarman \& Herma Hill Kay eds., 1990). Those scholars have also developed insight into how dominant legal rules that reproduce those meanings can be challenged practically through court process, legal storytelling, and reconstruction of legal doctrine and method. See, e.g., Christy Chandler, Race, Gender, and the Peremptory Challenge: A Postmodern Feminist Approach, 7 YALE J.L. \& FEMINISM 173 (1995); Trina Grillo, The Mediation Alternative: Process Dangers for Women, 100 YALE L.J. 1545 (1991); Mary Jane Mossman, Feminism and Legal Method: The Difference it Makes, in AT THE BOUNDARIES OF LAW 283 (Martha Albertson Fineman \& Nancy Sweet Thomadsen eds., 1991); Elizabeth M. Schneider, The Dialectic of Rights and Politics: Perspectives from the Women's Movement, 61 N.Y.U. L. REv. 589 (1986); Vicki Schultz, Telling Stories About Women and Work: Judicial Interpretations of Sex Segregation in the Workplace in Title VII Cases Raising the Lack of Interest Argument, 103 HaRv. L. Rev. 1750, 1840-43 (1990).

255. Environmental justice scholars recently have urged a related praxis approach to "lawyering for social change" for poor people and racial communities. See Cole, supra note 246 , at $667-68$. Studies from the late 1980 s and early 1990 s revealed the inordinately heavy burden borne by racial communities and the poor as a result of environmental policies and law enforcement practices. See Commission for Racial Justice, United Church of Christ, Toxic Wastes and Race in the Untted States: A National Report on the Racial and SOCIO-EConomic Characteristics of Communities with Hazardous WASTE SITES (1987). The traditional theoretical model of environmental lawyering failed to protect or further the interests of those groups. Environmental justice scholars have thus attempted to integrate theories of race and class oppression with environmental law practice.

Environmental justice rests on many factual assumptions and theoretical insights articulated by critical race theorists, see supra notes $228-42$, and poverty law scholars. See Anthony V. Alfieri, Reconstructive Poverty Law Practice: Learning Lessons of Client Narrative, 100 YALE L.J. 2107 (1991) (advocating the use of critical storytelling in poverty law practice); Christopher P. Gilkerson, Poverty Law Narratives: The Critical Practice and Theory of Receiving and Translating Client Stories, 43 HAstings L.J. 861 (1992) (arguing for the incorporation of client narratives in poverty law advocacy). One assumption is that, in general, racial communities and the poor "understand both the need to use the law and that the system is stacked against them." Cole, supra note 246, at 648. This assumption leads to the theoretical insight of "multiple consciousness," or the "dual . . . consciousness [of racial minorities toward law] which allows survival despite oppression." Id. A second assumption is that "most problems faced by [the poor and people of color] are not [just] legal problems, but political and economic ones." Id. This leads to the insight that "[e]ven if the law is 'on their side,' unless [they] have political or economic power as well, they are not likely to prevail." Id. A third assumption is that "[w]hile environmental problems disproportionately burden poor people and people of color, they cut across race and class boundaries." Id. at 633. This leads to the insight of the potential and need for "building multi-racial, multi-class and multicultural movements to address structural problems in society." Id.

These factual assumptions and theoretical insights inform a legal praxis that views justice in social structural terms and "embrace[s] ... tenets of client empowerment[,] group representation[,] and law as a means, not an end." Id. at 661. It views law and "legal tactics in the context of broader strategies." Id. at 654. Contextual analyses are translated in concrete situations into practical or operational terms through evaluative questions. For Luke Cole, the three practical questions for evaluating rhetorical and action strategies and tactics aimed at particular situations of environmental injustice are: Will it educate? Will it build political movements? Will it address root problems, rather than just symptoms? See id. at 668; see also Sheila Foster, Race(ial) Matters: The Quest for Environmental Justice, 20 Eco. L.Q. 721 (1993). 
performative, the material, and the reflexive. They are not offered as a universal theory of justice, nor do they prescribe what racial justice is, or should be, in any particular situation. Rather, for those confronting concrete racial conflicts in an attempt to forge "right relationships," the starting points offer guideposts toward collective, reflective antisubordination practice. ${ }^{256}$ The earlier discussions of Ho and United Minorities and the next section's discussion of critical race praxis implications provide a glimpse of the use of those starting points in concrete controversies, both as a critique of ongoing justice practice and as a guide toward future reflective action.

The "conceptual" starting point encompasses critical socio-legal analysis and translation. Critical socio-legal analysis examines the racialization of a controversy and the interconnecting influences of heterosexism, patriarchy, and class, and locates that examination within a critique of the political economy. It thus focuses on both the particulars and the context of a relationship in conflict.

The analysis starts with an examination of the claims emerging from a controversy, their traditional sources of authority, the supporting evidence, and the requested remedy - more or less an ordinary investigation of a legal claim. In addition, socio-legal analysis employs tools of critical inquiry in two respects. First, it

256. See John Paul Lederach \& Ron Kraybill, The Paradox of Popular Justice: A Practitioner's View, in The Possibility of Popular Justice: A CASE STUdy of Community Mediation IN tHe United States 357, 369 (Shelley Engle Merry \& Neal Milner eds., 1994) [hereinafter MERRY \& MrLNER] (describing the forging or restoring of "right relationships" as an end of justice). The race praxis starting points for collective, reflective action resemble the United Church of Christ's prophetic methodology called "See-Judge-Act." See Rev. Robin Petersen \& lou Ann Parsons, See-Judge-Act. Pastoral Planning for a Pro. PHETIC ChURCH (1994). Drawn from Latin American and South African liberation theology, this "praxis cycle" starts with the "See" phase. Seeing begins with concrete experiences, the stories, of those involved in a justice controversy; not just stock stories repeated by those with media control, but also stories from the inside expressing human reactions and interpreting social information. Collected stories, which provide often varying histories of the controversy, are then subjected to critical social analysis. See id. at 5 . That analysis probes deeply into foundational questions, asking why one group apparently is suffering at the hands of another, challenging assumptions underlying common beliefs about the groups involved and their relationship, and scrutinizing social structures (political, economic, social) for "root causes" of problems. See id. at 22-24. The goal of this analysis is group awareness, or acknowledgment, as a communal foundation for informed group action. The "Judge" phase is discernment - the identification and integration of guiding, and for the United Church of Christ, theological, principles and values. See id. at 26-27. Judging is not so much ascertaining right or wrong as discerning "what needs to be done" in light of those principles and values. Discernment thus takes the results of critical social analysis and asks what illumination these principles or values shed on appropriate courses of action and on responsibility for undertaking those actions. The third phase, "Act," involves engagement. This means goalsetting, planning, and affirmative steps. See id. at 32-34. In bureaucratese, it means plan implementation; in drama-speak, it means performance. The See-Judge-Act cycle closes with evaluation - evaluating how the three phases played out in the actual justice controversy and reflecting on how the process influences the experience. See id. at 34-35. 
assesses the justice setting and the implications of the potential "legalization" of the conflict - the way in which substantive norms and procedural rules are likely to be construed and applied in light of both methodological constraints and the interests of and power alignments among storytellers, advocates, mediators, and decisionmakers on the one hand and politicians, businesses, governmental bureaucrats, and community groups on the other. ${ }^{257}$ Second, critical socio-legal analysis identifies larger justice grievances possibly underlying the specific claims. It aims to break apart distorted cultural representations undergirding intergroup tensions, to challenge group deployment of oppressive rhetorical, institutional and economic structures, and to rearticulate group identities and conceptualize redress of justice claims, when appropriate, to foster intergroup healing and reconciliation. ${ }^{258}$ The socio-legal insights gleaned from these inquiries by theorists, lawyers, and community leaders are then translated into operational language for individuals and groups undertaking "actions" to redress grievances and forge alliances. ${ }^{259}$

Action is part of the "performative" starting point of a race praxis. Performance comes in at least two parts. The first involves the question of "what?" What practical steps are responsive not only to the specific claim but also to subtext - the underlying disparaging cultural images and exercises of group power that intensify historical intergroup grievances? This means acting upon the operationally translated insights of critical socio-legal analysis, "performing" in the specific setting to dismantle subordinating social structures and to rectify injustice. ${ }^{260}$

257. See supra Part II. See generally Cass R. Sunsten, Legal Reasoning and PolitICAL CONFICT (1996) (describing legal reasoning as it is actually practiced).

258. See supra notes 212,256 and accompanying text (concerning critical socio-legal analysis).

259. See infra section IV.B.1 (grounding race and justice theories in the concrete particulars of frontline controversies).

260. The ways theorists can engage or "perform" are many and varied, including working with or advising political organizations; litigating or consulting with litigation teams; supervising law students on cases challenging institutional authority or actions; lobbying legislative and administrative bodies on behalf of specific organizations; working with or serving on boards of social service and legal service groups; cultivating relations with journalists covering community justice issues; writing journalistic essays; writing critical socio-legal analyses and developing advocacy positions on specific issues for organizations; drafting legal briefs; doing legal historical research for community groups; training lay lawyers; and giving issue and strategy presentations to community groups. See supra note 66. As a law professor, I have endeavored to engage in many of these activities in collaboration with community leaders and groups, theorists, political lawyers, and legal advocacy organizations. These collaborative experiences form a foundation for much of my theory writing. See, e.g., Yamamoto et al., Cultural Performance, supra note 238; Yamamoto, Efficiency's Threat, supra note 118; Yamamoto, Rethinking Alliances, supra note 149. 
The second part of the performative dimension involves the question of "who?" Who should act? Put more specifically, given my assumption that political lawyers and community activists will participate, should scholar-theorists engage with the lawyers, organizations, and institutions and endeavor to influence the storytelling and decisionmaking of a controversy? The praxis response is a strong yes. One conclusion I draw from interactions with political lawyers and community activists is that theoretical insights about race and critical socio-legal analyses of particular controversies are unlikely to be meaningfully developed and translated for frontline antisubordination practice unless theorists personally engage with the difficult, entangled, shifting realities of that practice. The disjuncture between progressive race theory and political lawyering and community activism, I suspect, not only chokes useful theory development and translation, it stiffes contemplation of multilayered actions designed to produce material change.

The "material" starting point of a race praxis is the counterpart to performativity - the intended consequences of conceptual analysis and performance. It means inquiring into changes in the material conditions of racial oppression. Change is material when it occurs simultaneously at two levels. Change must be social-structural; it encompasses fair access to housing and to educational and job opportunities, the redistribution of societal goods, and the remaking of the democratic structure of public institutions. ${ }^{261}$ Change must also be representational; it entails the reassessment of group cultural traits and the rearticulation of racial identities and relationships. ${ }^{262}$ The material starting point thus directs praxis efforts toward both the structural and the discursive.

Finally, the "reflexive" starting point alerts theorists, lawyers, and activists to reintegrate experience into the theoretics of practice. It signals the continual rebuilding of theory in light of the practical experiences of racial groups engaged in particular antiracist struggles, thus recasting the conceptual, performative, and material dimensions of a critical race praxis. ${ }^{263}$

261. See Guyora Binder, What's Left?, 69 Texas L. REv. 1985 (1991).

262. See OMI \& WINANT, supra note 40 , at $83-86$ (describing racial changes having representational and social structural components).

263. These starting points help to assess the philosophy, goals, and procedures of the movements to remake civil justice in post-civil rights America. Those movements include the reform of the federal courts pushed by Congress as well as by, or sometimes in competition with, the federal judiciary, see Judith Resnik, History, Jurisdiction, and the Federal Courts: Changing Contexts, Selective Memories, and Limited Imagination, 98 W. VA. L. Rev. 171 (1995) (describing proposed restructuring of federal court system); the alternative dispute resolution juggernaut supported by most legislators, judges, lawyers, and organizations, see 


\section{B. Implications}

What are the main implications of critical race praxis and its starting points?, bearing on the problems of disjuncture and dissociation described earlier. The first is the need to ground justice in concrete racial realities; the second, the reframing of racial justice claims and court process as cultural performances; and the third, the development of an interracial praxis.

\section{Justice and Racial Realities}

One general implication of racial justice as praxis is the grounding of racial justice in concrete places, events, and group interactions. Practical justice is located in the messy social realities people see, hear, touch, and sense, and it takes account of how subordinated racial groups experience justice efforts.

Traditional theories of justice tend to be highly abstract and to speak past social realities. They embrace broad principles of political and moral philosophy, scrutinizing law's theoretical legitimacy 264 Separating justice into three conceptual camps distributive, corrective, and procedural - traditional theories tend to translate poorly into concrete approaches for understanding and addressing pressing real-life racial conflicts and prospects of remediation or healing. 265

Critical race praxis, with its conceptual, performative, and material starting points, grounds racial justice in concrete situations. Rather than beginning and ending justice analysis with philosophical ideas or the opinions of appellate judges, it starts with inquiry into the experiences and perceptions of racial groups and frontline justice practitioners. The Prologue's description of $H o$ provides a glimpse of the complex, shifting racial dynamics lying just beneath the surface of the litigation's engagement with general legal princi-

Eric K. Yamamoto, $A D R$ : Where Have the Critics Gone?, 36 SANTA Clara L. Rev. 1055, 1055-56 (1996) [hereinafter Yamamoto, $A D R$ ]; the possibilities of "popular justice" envisioned by political scientists and anthropologists, see MERRY \& MiLNER, supra note 256, at 3 (defining "genuinely popular justice" as "locally controlled, nonprofessional, and procedurally informal and that envisages a renewed community and decisions made according to community norms"); the "reconciliation through justice" advanced by theologians drafting the Kairos Covenant opposing South African apartheid, see THE KaIros Covenant (Willis $\mathrm{H}$. Logan ed., 1988) (prophetic theological challenge to apartheid in South Africa); the "law as part of larger political strategies" approach of environmental justice proponents, see Cole, supra note 246, at 654; and the community-centered problem solving of "rebellious lawyering," see LOPEZ, supra note 44.

264. See, e.g., John Rawls, A Theory of Justice (1971).

265. See ANThony D'Amato \& ARThur J. Jacobson, Justice and the Legal SysTEM 10 (1992); KenNeth MANASter, ENVIRONMENTAl Protection AND Justice 23 (1995). 
ples and specific procedural rules. A race praxis examines those dynamics and the people and organizations involved and focuses pragmatically on what theories and concepts provide workable approaches for understanding and diminishing oppressive racial conditions.

This grounding is important because it recommits theorists and activists to each other and to "making a difference" by connecting discourse analysis with justice practice and the material conditions of people's lives. As discussed earlier, progressive race theorizing tends to emphasize discursive strategies. Images and language oftentimes are mapped as the battleground. Indeed, the way we talk influences the way we think and act. That is why, when an interracial controversy arises, print and electronic journalists, politicians, scholars, businesses, and group spokespersons clamor for opportunities to shape ideas and images. During the post-Rodney King police trial firestorm, for example, the portrayal of interracial conflict by journalists (remember television shots of armed Korean American storeowners atop their shops) and politicians (recall President Bush's castigation of welfare dependency) created lasting impressions of intergroup hostility and sloth. Later, conciliatory, coalition-building efforts by African Americans, Asian Americans, and Latinos in South Central Los Angeles struggled not only with internal tensions over funding allocations and political voice but also with overwhelmingly negative public images of intergroup relations. When Chinese Americans in Ho launched a legal challenge to the San Francisco School District's court-ordered affirmative action program in 1994, the initial battle focused on competing racial portrayals of the lawsuit. Was the suit about "preferred" African Americans and Latinos displacing "better qualified" children of Chinese immigrants and whites, or, conversely, about Asian Americans oppressing African Americans and Latinos by carrying out neoconservative whites' designs to dismantle all affirmative action? At the level of ideas and images, discourses, or more precisely discursive strategies, embody power. Making a difference at least partially entails the power to tap communicative channels and the insight to reconstruct public events and rearticulate images and ideas about racial identities and group relations.

Progressive race theory's tendency toward preoccupation with discourse is problematic, however, because it comes at the overall expense of the concrete and particular. A quip attributed to an African American scholar vivifies the problem: understanding that race is a social construction does not help him get a taxi late at 
night.266 Dismantling disabling group constraints and redressing the group harms requires engagement in, and the connection of discourse analysis with, actual interactions among members of different racial groups in specific locales. At the face-to-face intergroup level, material goods, human interactions, access to political channels, along with discursive strategies, embody power. Making a difference entails the power and insight simultaneously to adjust the material aspects of race relations and to rearticulate intergroup identities.

The potential sites of interaction are many and varied and exist both within and beyond legal settings. Legal claims call forth several possible forums. Most legal claims are settled outside the courtroom through the joint efforts of parties, attorneys, and sometimes judges. Participants in a case construct and agree upon the controversy's resolution. Even when claims are not settled, and a court enjoins a defendant from specific future discriminatory behavior, some degree of cooperation and trust is required of the parties to prevent eruptions over the defendant's compliance efforts. In addition, other opportunities exist, and are often encouraged, to resolve legal claims outside the formal litigation process. Methods of alternative dispute resolution, such as mediation and arbitration, with greater informality and speed, are employed by choice of participants or by court order. ${ }^{267}$ Each of these sites for the resolution of legal claims enmeshed in racial conflicts offers opportunities for racial justice inquiry, rumination, and action. ${ }^{268}$

Myriad other sites also provide opportunities for the resolution of justice claims at and beyond the edges of formal law. Religious denominations, such as the United Church of Christ and the Southern Baptists, integrating insights of theology, law, and social psychology, wrestle with racial conflict and healing at both national and local polity decisional meetings. ${ }^{269}$ Labor unions offer tolerance workshops and adjudicate highly charged group-based grievances concerning racism not only by outsiders but also within their own ranks. Racial coalitions sometimes coalesce and then splinter in search of political or economic common ground, foundering on

266. See David Roediger, The Abolition of Whiteness 1 (1994).

267. See generally Yamamoto, $A D R$, supra note 263 (describing wide and increasingly less critical embrace of alternative dispute resolution).

268. See generally MERRY \& MILNER, supra note 256, at 4.

269. See Yamamoto, Rethinking Alliances, supra note 149, at 39 (discussing United Church of Christ national and local apologies to Native Hawaiians for complicity in overthrow of sovereign Hawaiian government and in destruction of Hawaiian culture). 
unacknowledged long-held intergroup stereotypes and grudges. 270 Students on university campuses, seeking to interact across groups in dormitories and classes, bring with them from the social world intergroup baggage loaded with misunderstandings and tensions. Racially charged economic boycotts bring groups face-to-face, sometimes on collision courses, often at high decibel levels. ${ }^{271}$

Each of these sites, or situations, compresses the conflicting drives of racial groups. One drive is toward peaceable relations: the desire to make peace and reconcile; to live side by side if not together; to work and play with each other. The other drive is toward separation: the desire to attack perceived misuses of group position and power by others; to distance one's group from the offending other. For each of these widely varying sites, critical race praxis directs race scholars and political lawyers to integrate their efforts and ground them in the concrete social realities of racial communities' struggles for justice.

\section{Justice Claims and Legal Process as Cultural Performances}

A second general implication of seeing racial justice as praxis is an expanded vision of courts, legal process, and justice claims as integral components of larger cultural performances. This praxis notion of justice claims and legal process as cultural performance speaks to those working with legal claims framed within "broader political strategies."272

Critical race praxis deepens the notions of community-based law advanced by López and Cole and reframes processes of legal justice for racial minorities in terms of cultural and communicative limitations and possibilities. It recognizes justice claims and legal process as an integral part of political-cultural processes that generate "structures of meaning that radiate throughout social life and serve as part of the material people use to negotiate their understanding

270. See Haunani-Kay Trask, Coalition-Building Between Native and Non-Natives, 43 StaN. L. Rev. 1197, 1205-13 (1991).

271. Some see these racial-political disputes as disguised issues of free speech law and laissez faire economics - media and legal scholars quickly cast the Korean American political association's boycott of Ice Cube's "Black Korea" rap in that fashion. See Jeff Chang, Race, Class, Conflict and Empowerment: On Ice Cube's "Black Korea," Amerasia J. Vol. 19, No. 2, 1993, at 87, 93-96 (describing how whites "created a defining perspective" in narrowly legalist terms of "whether . . . content required censorship"). Others frame the disputes around issues of local business and cultural respect - community organizations so described the African American boycott against inner-city Korean American merchants in New York. See id. at 88.

272. See Cole, supra note 246 , at 648. 
of everyday events and relationships."273 It searches critically for ways to locate justice processes and outcomes within larger community struggles; it searches pragmatically for resonance within racial communities.

A multifaceted antisubordination practice for communities of color can start with judges and lawyers and legal process - most Americans, to some degree, are familiar with legal systems. It can, and I assert should, start with law, because substantive legal principles of equality, liberty, and fairness, and legal process values of dignity and participation, at least in the abstract, provide a strong modernist core. ${ }^{274}$ But, as discussed, often legal doctrines are narrowly drawn and legal principles and values are vaguely stated. While their abstract appeal persists, their practical manifestation for many racial minorities fails to resonate.

Critical race praxis, with its emphasis on critical pragmatism and multidisciplinarity, suggests reconfiguring notions of legal justice to encompass racial community understandings of conflict, redress, and healing - understandings illuminated by a mix of law, history, theology, social psychology, political theory, and ethnic or indigenous cultural practices; understandings that play out in the daily practices of business, bankruptcy, labor, landlord-tenant, immigration, and family law as well as evidence and procedure. ${ }^{275}$ Reconfiguring legal justice in this way entails rethinking the functions of courts, judges, lawyers, and community organizations and acknowledging the cultural dimensions of justice claims and legal process. Racial justice can be reframed beyond traditional institutional legal players. It can embrace the idea that courts and law stimulate socio-cultural thinking about justice and that jury verdicts and narrow legal judgments alone do not necessarily define what is just for racialized communities.

As I have written elsewhere, ${ }^{276}$ vantage point is key. From one view, courts are simply deciders of particular disputes involving specific parties according to established norms. From another view, courts are also integral parts of a larger communicative process. Particularly in a setting of hotly contested racial controversies,

273. Trubek, supra note 94 , at 124.

274. See Frank I. Michelman, The Supreme Court and Litigation Access Fees: The Right to Protect One's Rights, 1973 DukE L.J. 1153, $1172-73$ (identifying litigation process values of dignity, participation, deterrence (or social welfare) and effectuation).

275. See Yamamoto, Rethinking Alliances, supra note 149, at 65 (summarizing ways in which disciplines other than law address intergroup healing and reconciliation).

276. Much of the next two pages, including citations, is taken more or less verbatim from part of an earlier work. See Yamamoto et al., Cultural Performance, supra note 238, at 17. 
courts tend to help focus cultural issues, to illuminate institutional power arrangements, and to tell counter-stories in ways that assist in the reconstruction of intergroup relationships and aid larger social-political movements. In those situations, court process can be seen as a cultural performance and justice can be viewed in part as the transformation of oppressive dominant racial and cultural narratives.

As Gerald Torres and Kathryn Milan observe, "[w]ithin a society, there are specific places where most of the activities making up social life within that society simultaneously are represented, contested, and inverted. Courts are such places."277 This observation is reinforced by the studies of socio-legal scholars that conclude that case handling by courts can be viewed as "cultural performances, events that produce transformations in socio-cultural practices and in consciousness." 278 Those transformations may tend to be repressive, legitimizing harsh imbalances of power in social relationships; they may tend to be liberatory, opposing, or reconfiguring, entrenched group images and relationships; or they may reflect some complex, shifting combination of the two. Those transformations may occur as accretions over time, little noticed; or they may emerge in the jolt of a singular case-event. Of course, relatively few court cases singularly produce transformations in socio-cultural practices and in consciousness. Those that do tend to occur when the legal dispute is reflective of a larger, ongoing social-political controversy. Other factors - location, media attention, community organizing, related lawsuits, and legislative initiatives - are significant.

This view of courts as dynamic sites and generators of cultural performances is supported generally by dispute transformation theory. According to this theory, each stage of the court process in varying ways contributes to a "rephrasing" of the dispute. ${ }^{279}$ Decisions concerning initial claim assertion followed by decisions concerning pretrial discovery, sanctions, and overall case management - including motions, settlement maneuvering, and legal-issue formulation - redefine the claimant's understanding and framing of

277. Gerald Torres \& Kathryn Milun, Translating Yonnondio: By Precedent and Evidence: The Mashpee Indian Case, 1990 Duke L.J. 625, 628 (footnote omitted).

278. Sally E. Merry, Law and Colonialism, 25 LAw \& Socy. Rev. 889, 892 (1991).

279. See William L.F. Felstiner et al., The Emergence And Transformation Of Disputes: Naming, Blaming, Claiming . . , 15 LAw \& SocY. REv. 631 (1980-1981); Lynn Mather \& Barbara Yngvesson, Language, Audience and the Transformation of Disputes, 15 Law \& Socy. Rev. 775, 780 (1980-81); see also Bryant G. Garth, Power and Legal Artifice: The Federal Class Action, 26 LAw \& Socy. Rev. 237, 240 (1992). 
the controversy. The interactions among parties, attorneys, judge, court personnel, community groups, and general public, through the media and the trial itself, further contribute to this rephrasing at the trial court level. Decisions by appellate courts, more detached and, in some respects more far-reaching, further solidify the court system's dispute rephrasing performance. As Mather and Yngvesson observe, a legally phrased claim is a "social construct which orders 'facts' and invokes "norms' in particular ways - ways that reflect the personal interest or values" of the describer. ${ }^{280}$ Concerns critical to the rephrasing process thus arise: Who has court access; who controls claim development and presentation; according to what standards and from what perspectives; who reports on the contextual facts; and according to what selection criteria? What cultural values collide and emerge in the interactions of judges, parties, attorneys, communities, and media? These concerns shape the contours and content of a court system's overall cultural performance. From this view, courts in important instances not only decide disputes, they also transform particular legal controversies and rights claims into larger public messageș. 281

Those messages. can be thought of as socio-legal narratives about groups, institutions, and their interactions. The shaping and retelling of stories through court process can help either to reinforce or to counter a prevailing cultural narrative in a given community. A prevailing, or master, narrative provides a principal lens through which groupings of people in a community see and interpret events and actions. It provides a set of basic assumptions for evaluating social-political controversies and the relationships of the groups involved. ${ }^{282}$

A, counternarrative challenges those assumptions and the vantage point from which they are made. By offering a "framework not previously accepted," the counternarrative challenges "established categories for classifying events and relationships by linking subjects or issues that are typically separated" or by elevating previously suppressed voices, thus "stretching" or changing accepted frameworks for organizing reality."283 It thereby undermines the

280. Mather \& Yngvesson, supra note 279, at 780; see also Judith Resnik, On The Bias: Feminist Reconsiderations of The Aspirations For Our Judges, 61 S. CAL. L. REv. 1877, 1905 (1988) (noting that judicial judgment cannot escape the inevitability of perspective and choice of those who judge).

281. See Yamamoto et al., Cultural Performance, supra note 238, at 20-21.

282. See id. at 21-22.

283. Mather \& Yngvesson, supra note 279, at 778-79; see also Delgado, Storytelling for Oppositionists, supra note 239. 
clarity and strength of the master narrative by infusing complexity and providing a competing perspective.

Historically, for example, master socio-legal narratives about indigenous groups have tended to characterize their subordinated situations as inevitable, due to the groups' inferiority, or as insignificant, due to the passage of time and past remedial efforts. ${ }^{284}$ Subordinating socio-legal narratives have thus long fixed blame for Native Hawaiians' physical and cultural destruction on their inferiority and "semi-barbarous face."285

Court rulings have reinforced such master narratives, and harsh societal actions have been justified by them. Many racialized groups now counter master cultural narratives with narratives of their own - not only telling stories of historical and contemporary victimization but also offering normative precepts for future social structural change. These counternarratives are rooted in history and culture. And they are rooted in law.

There is growing recognition of the power of legal storytelling in the construction of counternarratives in legal process. Nell Newton describes how "claims stories [by Native Americans], when broken from the dry legal recitation of the facts in the cases and placed in context, reveal powerfully the inadequacies of the dominant group's stories."286 In this setting, racialized groups and indigenous groups in particular are both asserting rights claims within narrow and expansive frameworks and rethinking and recasting the "cultural performance" role of courts in addressing race-political controversies.

This rethinking parallels shifting perceptions of the judicial role in civil rights litigation. It reflects in part the transformation from the civil rights activity of the 1960 s and early 1970 s to the post-civil rights era.287 For racial minorities, the current post-civil rights era might be characterized generally by a reconceptualizing of the role of courts and law as part of, rather than as the pinnacle of, political strategies for social structural change; the movement away from

284. See Nell Jessup Newton, Indian Claims in the Courts of the Conqueror, 41 AM. U. L. REv. 753, 760-61 (1992); see also S. James Anaya, The Rights of Indigenous Peoples and International Law in Historical and Contemporary Perspective, 1989 HARV. INDIAN L. SYMP. 191, 199-204 (1990); Robert A. Williams, Jr., Encounters on the Frontiers of International Human Rights Law: Redefining the Terms of Indigenous Peoples' Survival in the World, 1990 Duke L.J. 660, 673-76. See generally Charles F. Wilkinson, American Indians, Time, AND THE LAW (1986).

285. See 26 CONG. REc. 1885 (1894).

286. Newton, supra note 284 , at 760 .

287. See Yamamoto et al., Cultural Performance, supra note 238, at 26 (describing the transformed role of courts and rights litigation in post-civil rights America). 
principal reliance on narrow judicial remedies toward the additional use of courts as forums for the development and expressions of counter-narratives and for the promotion of local empowerment and community control; and a rising importance of state or other local forums for developing and hearing outsider claims. ${ }^{288}$

\section{Interracial Praxis: Beyond the White-Black Jurisprudential Paradigm}

By grounding justice inquiry in concrete group experiences and envisioning justice claims and legal process as components of cultural performances, critical race praxis asks, "In what kinds of racial controversies is the law experienced as dissociated from justice?" More specifically, what kinds of justice claims for racial minorities fall beyond the limits of contemporary antidiscrimination law? One response is claims to interracial justice. Those claims in concept and practice appear to exceed the boundaries of the white-black jurisprudential paradigm and yet are constantly cast within it. ${ }^{289} \mathrm{~A}$ third implication of thinking about racial justice as praxis thus is expanded jurisprudential inquiry into a realm largely ignored by courts and legal scholars. This inquiry is attentive to continuing white influence over all facets of race relations in America and recognizes the unique effects of slavery for African Americans. It nevertheless moves beyond binary oppositions of white versus black, majority versus minority, perpetrator versus victim. It endeavors to shift from margin to center issues of interminority justice.

This expanded inquiry takes seriously not only interminority competition and conflict but also the social and legal ramifications of continued intergroup tension on the one hand and healing and reconciliation on the other. Indeed, the intensifying call by many for deepening alliances and broader coalitions among communities of color means heightened attention to intergroup healing and reconciliation. As Elizabeth Martinez observes, in light of the pain of intergroup prejudices, resentments, and competition, alliances among groups of color "require a knowledge and wisdom that we have yet to attain." 290

288. See id. at 27.

289. See Martinez, supra note 149; Yamamoto, Rethinking Alliances, supra note 149; Beyond Black and White: Race-Conscious Policies and "Other Minorities" in Conference, Race, Law and Justice: The Rehnquist Court and the American Dilemma, 45 AM. U. L. Rev. 601 (1996).

290. Martinez, supra note 149 , at 22. 
An interracial praxis, moving beyond the white-black jurisprudential paradigm, addresses intergroup prejudices and resentments as well as possibilities for healing and reconciliation. It focuses on the obstacle of felt injustice in the struggles of groups endeavoring to "live together peaceably and work together politically."291 I develop the full dimensions of an interracial praxis in a forthcoming work. ${ }^{292}$ The remainder of this section sketches one aspect of that praxis: inquiry into racial group agency and responsibility. I discuss this aspect of interracial praxis because, in contemplating the dissociation of law from racial justice, it rethinks the framing and handling of interracial justice grievances underlying many intergroup conflicts and legal claims.

An interracial praxis rethinks concepts of colorblindness, group fungibility, hierarchy, cultural discrimination, and multiracial conflict, among others; and it examines in concrete controversies how those concepts, employed by courts, legislatures, administrative bureaucracies, schools, churches, and the media, shape interracial identities and relationships, construct intergroup conflicts, and fashion dispute resolution possibilities. ${ }^{293}$ As part of that critical sociolegal interrogation, an interracial praxis assesses complex power arrangements often undergirding particular intergroup conflicts and justice claims especially where one group with some emergent socio-political power is charged by another group with redeploying structures of oppression. For example, in Ho and in United Minorities, African American, Asian American, and Latino intergroup power relationships are productively assessed according to a theory of power that recognizes that members of racialized groups are neither fully autonomous nor puppets controlled by others but are instead social actors empowered and constrained by multiple socioeconomic settings. Such a situated theory of power ${ }^{294}$ acknowl-

291. Yamamoto, Rethinking Alliances, supra note 149, at 33.

292. See ERIC K. Yamamoto, RACE, CULTURE AND REsponsibility: INTERRACIAL JuS. TICE IN POST-CIVIL RIGHTS AMERICA (forthcoming 1997).

293. See supra notes $215-19,252-63$ and accompanying text.

294. The idea of situated power departs from prevailing polarized ethnicity (all culture) and nationalism (all structure) views of racial group agency. See Yamamoto, Rethinking Alliances, supra note 149, at 53-56 (describing neoconservative ethnicity theory's "autonomous agent" approach and the polar colonialism-nationalism "no agency" structuralist approach). Drawing upon Thomas Wartenberg's exploration of the dynamics of one group's "power over" another, see Thomas E. WARTENBERG, The Forms OF POWER: From Domination TO TRANSFORMATION 71 (1990), a situated power approach suggests that racial group agency and responsibility are both enlivened and constrained by context. Power over is understood as one group's capacity in a particular socio-political setting, or "field," to constrain the action alternatives of another group. See id. at 71-72. Those group action alternatives involve self-definition (identity), self-perpetuation (culture and economics), and self-determination (politics). 
edges the capacity of racial groups, amid changing racial demographics and socio-economic structures, to be simultaneously oppressed and oppressive, liberating and subordinating. ${ }^{295}$

This idea of situated group power, generally stated, yields four understandings about racial group agency enlivened and constrained by context. Those understandings, summarized here, which illuminate a praxis view of intergroup conflicts and healing prospects, are simultaneity, positionality, differentiation, and dominance-transformation.

The first understanding is simultaneity. It means that a racial group can be viewed as uplifting and subordinating, oppressed and oppressive, depending on the power relationships involved. Simultaneity is characterized by racial groups that have resisted domination from above and have obtained some degree of socio-economic power, and that situationally redeploy structures oppressive to them to oppress others. ${ }^{296}$ Those structures can be political, cultural, economic, or rhetorical in form. Rey Chow observes that as multiculturalism and "rhetorical claims to political change and difference" are advanced, "many deep-rooted, politically reactionary forces return to haunt us." The "new solidarities" generated by these forces "are often informed by a strategic attitude which repeats what they seek to overthrow. The weight of old ideologies being reinforced . . . is immense."297 Simultaneity is a particular phenomenon of "borderland sites" - "locales in which situations historically oppressive to racial [and other outsider] groups are undergoing demographic, economic and socio-political change" and are marked by "continuing struggles for identity and power."298

The second understanding is positionality. It builds upon and deepens the idea of simultaneity. It means that racial group agency needs to be understood as multirelational. Each social actor is engaged in multiple relationships. Relationships defined at least in part by race, class, gender, culture, sexual orientation, age, disability, or locale implicate different axes of power. Each axis of power forms a context within which domination can occur. Social actors thus are situated within multiple relational contexts, with possibilities for dominating and being dominated. "Victims can also be vic-

295. See Yamamoto, Rethinking Alliances, supra note 149, at 58 (articulating the notion of agency constrained and enlivened by social settings).

296. See id. at 52.

297. Rey Chow, Writing Diaspora: Tactics of Intervention In Contemporary Cultural Studies 16-17 (1993).

298. Yamamoto, Rethinking Alliances, supra note 149, at 52 (discussing postcolonial theory and the concept of "borderland sites"). 
timizers; agents of change can also be complicitous, depending on the particular axis of power ....'299 This explains an agent's potential for simultaneity, for being privileged and oppressed.

Positionality extends simultaneity by providing insight into the deeply layered notion of responsibility. It does so by focusing on the position and comparative power of an actor within each relationship, within each context. Identifying an actor's power position within a given context helps identify its potential as an agent or object of domination, or both. This means that an actor may be oppressed within one context, may therefore make justice claims against those with power over that actor in that context, may also be oppressive in another context, and may therefore be responsible for the justice claims of those over whom it exerts power. Feminist legal theory at the crossroads of race and gender, with its interrogation of white women's racial privilege, provides insight into this "relational positionality."300

The third understanding is differentiation. The ideas of simultaneity and positionality, drawn from postcolonial and feminist legal theory, explain multiple relational contexts and the potential of social actors to be both oppressed and oppressive. They also address the importance of evaluating the power positions of an actor within each of many relationships and identifying differing axes of power and systems of potential domination. They do not, however, address interracial dominance - how within a system or context of racial domination, where racial minorities are struggling against white domination, a nonwhite racial group acquires and exercises power over another.

Differential racialization and the related notion of differential disempowerment assist in this inquiry. ${ }^{301}$ These anti-essentialist ideas highlight differential power among racial groups as a central feature of interracial conflicts. They recognize that racial groups are racialized differently - that varying historical experiences and current socio-economic conditions create different racial images, status and power among racial groups, and that those differences contribute to intergroup conflict. ${ }^{302}$ Both ideas account for differential racial group agency in the construction and maintenance of

299. Susan Stanford Friedman, Beyond White and Other: Relationality and Narratives of Race in Feminist Discourse, Signs 1, 18 (1995).

300. See id. at 16-20 (describing relational positionality).

301. See Michael Omi, Out of the Melting Pot and Into the Fire: Race Relations Policy, in The State OF Asian PACIFIC America 207 (1993) (describing differential racialization within a racial group according to class differences).

302. See Yamamoto, Rethinking Alliances, supra note 149, at 59-60. 
racial hierarchies and differential racial group responsibility for dismantling those hierarchies. Rooted in critical sociology, differential racialization and disempowerment thus acknowledge that racial groups, even while themselves struggling against domination by others, sometimes, and in complex ways, exercise power over others and that this exercise of power occasionally generates or exacerbates interracial conflict. ${ }^{303}$

The final understanding, which relates to the others, is dominance-transformation. Reflecting the varying uses of one racial group's power over another, ${ }^{304}$ dominance-transformation also connects group agency with responsibility. It addresses this question: Under what circumstances does the exercise of one racial group's power over another disable the other in terms of self-definition or self-determination and thus entail responsibility for interracial healing? ${ }^{305}$

The extent of a racial group's power over another is determined in part by its alignment with other social (often institutional) actors within the group's field or socio-political setting. ${ }^{306}$ This notion of alignment within a field is significant, because in any single relationship the central actors can be involved with multiple alignments, creating shifting, colliding spaces for "power over." One group can have power over another under certain circumstances, and the power relationship can be reversed in other situations. Thus, at varying times, ethnic Chinese, Japanese, Korean, and Filipino Americans aligned with one another along Asian American racial lines to enhance political power, social voice, and entitlement distributions. ${ }^{307}$ That intragroup alignment heightened Asian American power in dealing with predominantly white-controlled institutions and in working with and competing against other minorities. In $H o$, however, when several Chinese Americans sued to invalidate courtmandated affirmative action in San Francisco's public schools, 308 Asian American alignments fractured. The Chinese American plaintiffs set themselves apart from other Asian ethnic groups. Sev-

303. See id.

304. See WARTENBERG, supra note 294, at 71-72.

305. See Yamamoto, Rethinking Alliances, supra note 149, at 58.

306. See WARTENBERG, supra note 294 , at 150 . Wartenberg's theory of situated power does not deal with race issues. The discussion here extends his theory into the realm of racial group power.

307. See Yen Le Espirtu, Asian American Panethnictry 14 (1992) (describing the coalescence of Asian ethnic groups in America into an singular Asian American racial identity).

308. Ho v. San Francisco Unified Sch. Dist., No. 94-2418 (N.D. Cal. Mar. 8, 1996). 
eral Asian American political organizations (including Chinese American groups) strongly opposed the suit. Other Asian American groups, along with white journalists, conservative scholars, university administrators, and politicians, supported the suit's goal by characterizing Asian Americans along with whites as victims of racial preferences for African Americans and Latinos. ${ }^{309}$ The alignment of neoconservative whites and Asian Americans with the Chinese American plaintiffs enhanced Chinese American power over African Americans and Latinos in the affirmative action arena.

At the same time, in the racialized debate about immigration, many whites and Asian Americans (primarily later generation and middle class) aligned with African Americans in support of California's Proposition 187 and other anti-immigrant measures, thus creating a nativist citizen versus foreigner discourse and locating middle class whites, Asian Americans, and a cross-section of African Americans against recent Asian and Latino immigrants. This alignment conferred even socially and economically struggling African Americans with some degree of power over recent Asian and Latino newcomers.

Group power, or agency, is derived in part from these kinds of fluid, shifting alignments with others in the larger field. These alignments in turn are rooted in history and contemporary social and economic conditions. Group agency is thus derived from both internal practices and social context. Agency itself, however, does not determine group responsibility. The racial group's choices in the use of its ebbing and flowing power over another determine its responsibility toward that other. ${ }^{310}$ Power over can be manifested in a particular context through dominance - not only direct oppression but also systemic subordination. It can also be manifested by transformation - acknowledging and restructuring or at least accounting for power imbalances. 311 The former generates racial harms for which the more powerful group bears responsibility. The latter reflects an acceptance of responsibility and affirmative steps toward interracial healing.

As part of a group's acceptance of that responsibility, an interracial praxis searches for practical, transformative exercises of "power over." In seeking to better connect law with racial justice, it looks

309. See supra notes 28-31 and accompanying text.

310. See Yamamoto, Rethinking Alliances, supra note 149, at 44.

311. See WARTENBERG, supra note 294 , at 183-84. 
at law and beyond into the healing realms of theology, social psychology, peace studies, and indigenous practices, and it recognizes that when groups seek to "live together peaceably and work together politically," especially in times of disruptive equilibrium, the healing of intergroup justice breaches and the rebuilding of intergroup relationships, often precede efforts to forge economic or political-action coalitions. 312

\section{CONCLUSION}

The opening of this article described the ongoing Ho and United Minorities cases and suggested that the litigation of those cases reveals a disjuncture between progressive race theory and political lawyering practice as well as an apparent dissociation of law from racial justice. It then presented a critical, pragmatic rethinking of antidiscrimination law practice in the context of a jurisprudence of reconstruction. And finally, it offered the beginnings of critical race praxis response to problems of disjuncture and dissociation and outlined three consequences of this approach - the grounding of justice practice in concrete racial realities, the reframing of courts and justice claims as cultural performances, and the development of an interracial praxis.

The epilogue concludes with another ongoing story. The story does not apply each of the critical race praxis starting points - the conceptual, performative, material, and reflexive. Nor does it directly illuminate praxis implications or generalize about "how to" practice racial justice. Rather the story is a brief account of one messy, concrete, incomplete intergroup race praxis effort. I leave for the reader the task of evaluating whether the critical race praxis starting points assist in assessing the efficacy and meaning of that effort and, perhaps more important, whether the starting points might provide meaningful guidance for future efforts.

\section{EPILOGUE}

Auntie Alice Aiwohi, a Native Hawaiian, died recently at 81. During adulthood she worked as a nurse on the island of Oahu, Hawai'i. Upon retiremerit she returned to the island of her birth, Moloka'i. Years earlier the State Department of Hawaiian Homelands awarded her a Homelands parcel in up-country Moloka'i. Upon her return, however, the Department prohibited her from living there. No money was available for electricity or water and 
sewer systems for Homelands, officials said, and none was forthcoming. Auntie Alice defied the Homelands Department; she and her seventy-five-year-old husband moved onto the parcel and lived in an empty Safeway shipping container. Electric generator. Carried-in water. Outhouse. There she taught Hawaiian language and history to young children and raised vegetables and flowers.

And there her anger simmered at having to defy state authority to do what seemed to her right and natural: to live on and care for Hawaiian land and to vitalize Hawaiian culture. Her anger was the anger of others. Recognizing the devastating effects on Native Hawaiians of the United States-aided overthrow of the Hawaiian nation, ${ }^{313}$ Congress created the Hawaiian Homelands Trust in 1921 to return a portion of illegally seized government and crown lands to Hawai'i's indigenous people. ${ }^{314}$ Administered first by the federal government and now by the state as trustee, Homelands reflect for many Hawaiians both a sacred relationship between Hawaiians and the environment and a potential political and economic base for Hawaiian self-governance. Homelands also symbolize continuing governmental misfeasance in the treatment of Native Hawaiians less than twenty percent of the Homelands are leased to intended trust beneficiaries; much of the prime lands are leased at low rents to non-Hawaiians, including politicians and agribusiness. Other lands, like Auntie Alice's, are deemed uninhabitable due to lack of infrastructure; 20,000 Native Hawaiians remain on the Homelands waiting list. ${ }^{315}$

Collective anger about Homelands mismanagement resurfaced in 1992 when the state proposed a plan to redress twenty-five years of illegal state confiscation of 30,000 acres of Homelands for non-

313. For accounts of Westem interests' destruction of Hawaiian life and culture, including the separation of Hawaiians from the land, see generally NATIVE HawAIIAN RIOHTS HAND. BOOK (Melody Kapilialoho MacKenzie ed., 1991); Lilikala KaME'Elehiwa, Native LaND and Foreign Desires: Pehea la E Pono ai? (1992).

314. The history of Hawaiian Homelands includes the United States-aided forceful overthrow of the Hawaiian monarchy in 1893 by a few American businessmen and religious leaders; the appropriation of all former government and crown lands by the United States upon annexation in 1898; the return of 200,000 acres in trust in 1921 for use by Native Hawaiians to "rehabilitate" them; the transfer of the Homelands Trust to the State of Hawai' $i$ upon statehood in 1959; the widespread mismanagement of the trust so that more than $60 \%$ of Hawaiian Homelands is in military and non-Hawaiian hands, and only $18 \%$ is occupied by Native Hawaiians; 20,000 Native Hawaiians are on the Homelands waiting list, and some have been there for decades. See generally HaWAII Adv. Comm. TO THE U.S. COMM. ON Civil Rigriss, a Broken Trust, The Hawainan Homelands Program: Seventy Years of Failure of the Federal and State Governments to Protect the Civil Rights of Native HawaIIANs (1991) [hereinafter A BROKEN TRUST]; Yamamoto et al., Cultural Performance, supra note 238, at 10-12 $\mathrm{nn} .32-35$.

315. See A Broken Trust, supra note 314. 
Homelands purposes (such as state roads and airports). To avoid breach-of-trust lawsuits, the governor's office formed a Task Force to determine "fair compensation," to settle Native Hawaiian claims. Consistent with its other actions, the governor's office sought to rectify injustice to Hawaiians and infuse working capital into the Homelands program while accommodating other state needs.

Problems arose at the outset. The Task Force was comprised of the governor's office (representing the state as principal wrongdoer in the trust breaches) and the director of the State Department of Hawaiian Homelands (representing the Department as passive wrongdoer). Both were advised by the State Attorney General (whose office had allowed the misappropriation for twenty-five years). Conflicts of interest abounded. A Native Hawaiian community advocacy group demanded to participate on the Task Force to represent the trust's beneficiaries. The Task Force said no, we'll do what's best for Hawaiians.

But the Task Force didn't. It sharply undervalued compensation claims. For example, one tract used by the state for years as a small airport was valued at one dollar per acre per year. In addition, the Task Force recommended that the state pay compensation only if the Homelands Department, on behalf of Native Hawaiians, waived rights to undercompensated or uncompensated claims. That waiver would likely eliminate the future assertion of claims against the state by a self-governing Native Hawaiian entity created to control Hawaiian lands.

Confusion ensued. Some believed that the state finally was acknowledging a wrong to Hawaiians and doing something about it. For the first time in years there would be money ( $\$ 5$ million to $\$ 12$ million immediately and $\$ 38$ million total) to build infrastructure on Homelands. Others, while agreeing with the settlement undertaking, reacted angrily to its process and outcome. Members of Hui $\mathrm{Na}^{\prime} \mathrm{ao}^{\prime} \mathrm{ao}$ (a coalition of 40 Hawaiian prosovereignty groups), the Kalamaula Homesteaders (of Moloka'i), and the West MauiMoloka'i Taro Farmers Association (a taro growers collective) responded thus: "Slammed-out again." "Lip service compensation. Where's the justice?" "That's what happens when the government takes our land, breaks our way of life and then tells us, don't worry, don't get involved, we'll take care of it." Auntie Alice also responded: "We've got to stop this, or they'll just keep doing it."

While long-simmering Hawaiian community frustration with the Homelands Trust boiled over, a small group of political lawyers and Hawaiian activists began to analyze the proposed release-waiver of 
claims and to scrutinize the appraisals supporting the Task Force's settlement calculations. As community leaders, political lawyers, and race-law theorists met, questions arose: Should Native Hawaiians resist? If so, how could they fight to participate in the settlement process and increase the settlement amount without scuttling the undertaking altogether? Of what use were the courts? The media? What political and legal outcomes were conceivable?

Initial liberal legal responses to questions about legal action were both complicated and refined by the critical, pragmatic inquiry. On the side of risk: What damage might be done by legalizing the dispute and situating it within a largely Western court system? Haven't Native Hawaiians consistently lost even their strongest breach-of-trust claims on procedural grounds? ${ }^{316}$ How were largely negative cultural narratives about Native Hawaiians inscribed in and reproduced by federal and state law concerning Hawaiian trust lands? Might the state, with its superior resources and appointed judges, control any legal proceeding and the public messages emanating from it? On the side of opportunity: How might court process assist in transforming dominant cultural-legal narratives about Native Hawaiians and Hawaiian Homelands? What reconstructed cultural messages about Native Hawaiians might be communicated - political and economic self-determination? cultural revitalization? recognition of agency and responsibility not only by whites, with a history of oligarchical control and present-day predominance over business and media, but also by Japanese and Chinese Americans, with disproportionate representation in local politics and government bureaucracy? How might these messages impact upon the larger sovereignty movement and connect with the justice struggles of Native Americans and indigenous peoples throughout the world? What might be the value of public airing of justice grievances and cross-examination of key government administrators? For what audiences? And with what backlash?

Following sometimes heated discussions, a core group formed. The group was comprised of Homelands and prosovereignty activists, Hawaiian, white, and Asian American attorneys from two Hawaiian legal advocacy groups, a Hawaiian attorney with a large-firm commercial litigation practice, and an Asian American law professor specializing in complex litigation and race theory. Although differing in its views on several issues, the group agreed that a 
favorable legal outcome, on the law alone, seemed unlikely. A suit's breach-of-trust and due process claims to eliminate the waiver and allow participation of an independent Hawaiian representative on the Task Force, while plausible, would be fraught with problems, including governmental immunity and political question obstacles. The group agreed, however, that on balance a legal challenge would likely "assist larger political strategies," especially in the context of the prosovereignty movement, the continuing protests against Homelands mismanagement, and the state administration's general openness to hearing Hawaiian justice claims. Finally, the group coalesced around the justice claims at stake: self-determination for, rather than paternalism over, Native Hawaiians; full compensation for illegally confiscated Homelands; and elimination of the broad waiver of claims.

Auntie Alice and Homelands activists Charles Ka'ai'ai and Robert Asing served as plaintiffs in Ka'ai'ai v. Drake. ${ }^{317}$ The prosovereignty activist on the core group kept Hui Na'ao'ao apprised of developments and prepared with responses to backlash from some state officials and Hawaiian groups about the "irresponsible obstructionists blocking needed money for Homelands."318 The core group organized press conferences and community group meetings to advance the plaintiffs' story. What followed included the filing of the complaint in federal court; the suit's voluntary dismissal and its refiling in state court; the public "trial" and cross-examination of key government officials on the temporary restraining order-preliminary injunction application; coverage by media and journalists; the granting of the restraining order (the first such order granted against the state in a Hawaiian land trust case); a partial settlement requiring the state to pay immediately the Task Force's recommended amount as a floor, not a ceiling, and eliminating the waiver-release; summary judgment for the state on political question grounds dismissing the claim for appointment of an independent representative to the Task Force; a stay of judgment while the core group lobbied successfully for legislation (and funding) authorizing the court to appoint an independent representative; the vacation of the summary judgment and the certification of a class action with subclasses; the court's selection and appointment of a Homelands beneficiary representative to the Task Force; the Task Force's reconsideration of all compensation claims, increasing its initial rec-

317. Civil No. 92-3742-10 (1st Cir. Haw., Oct. 1992).

318. Interview with William Meheula, Lead Counsel for Charles Ka'ai'ai et al., Ka'ai'ai v. Drake, in Honolulu, Haw. (March 25, 1994). 
ommendation from $\$ 38$ million to over $\$ 300$ million; and the 1995 legislature's commitment to pay to the Homelands Trust $\$ 30$ million a year for 20 years - $\$ 600$ million total.

The story, of course, continues. The Department of Hawaiian Homelands, which vigorously opposed the suit, now, with a new director, embraces its result; Homelands infrastructure is growing at an accelerated pace. Some Hawaiians celebrate the cultural messages conveyed to the public - the acknowledgement of longterm state-inflicted harm upon Hawaiians and the salience of present-day Hawaiian self-determination. Some worry, however, that for many Hawaiians the long, bitter wait will continue and that the settlement will hinder the push toward sovereignty. Others, including influential politicians, faced with a state fiscal crunch, worry about "too much, too fast" for Hawaiians and wonder about possibilities for rescinding the legislature's payment commitment. Still others among the public chafe at what they perceive as a "racial preference" for "undeserving Native Hawaiians."319 As mentioned, with this brief account of Ka'ai'ai v. Drake, ${ }^{320}$ I leave for the reader the task of evaluating whether the beginning critical race praxis starting points offered and praxis implications identified might help shape and assess collective, reflective antisubordination practice in messy, never-finished justice situations like this.

319. See Greg Barrett, Hawaiian Homelands: Long, Bitter Wait, Honolulu AdverTISER, Oct. 20, 1996, at A1.

320. Writing about what I do enables me to work from the inside out, to tell stories and generate structure from those stories. But it also sometimes limits my range of vision and obscures other viewpoints. These limitations color my brief account of $\mathrm{Ka}^{\prime} \mathrm{ai}^{\prime}$ ai $\mathrm{v}$. Drake. I was the law professor member of the core group, and my role was that of theoristproceduralist, class action counsel and participant-observer. See Yamamoto et al., Cultural Performance, supra note 238 , at $76 \& n .279$ and accompanying text for further discussion of the case. 